Florida International University FIU Digital Commons

7-5-2016

\title{
Water-Rock Interactions and Seasonal Hydrologic Processes in Constructed Everglades Tree Islands
}

Andres E. Prieto Estrada

Florida International University, aprie050@fiu.edu

DOI: $10.25148 /$ etd.FIDC000746

Follow this and additional works at: https://digitalcommons.fiu.edu/etd

Part of the Environmental Sciences Commons, Geochemistry Commons, Geology Commons, and the Hydrology Commons

\section{Recommended Citation}

Prieto Estrada, Andres E., "Water-Rock Interactions and Seasonal Hydrologic Processes in Constructed Everglades Tree Islands" (2016). FIU Electronic Theses and Dissertations. 2576.

https://digitalcommons.fiu.edu/etd/2576

This work is brought to you for free and open access by the University Graduate School at FIU Digital Commons. It has been accepted for inclusion in FIU Electronic Theses and Dissertations by an authorized administrator of FIU Digital Commons. For more information, please contact dcc@fiu.edu. 


\title{
FLORIDA INTERNATIONAL UNIVERSITY
}

Miami, Florida

WATER-ROCK INTERACTIONS AND SEASONAL HYDROLOGIC PROCESSES IN CONSTRUCTED EVERGLADES TREE ISLANDS

\author{
A thesis submitted in partial fulfillment of \\ the requirements for the degree of \\ MASTER OF SCIENCE \\ in \\ GEOSCIENCES \\ by \\ Andres Eduardo Prieto Estrada
}


To: Dean Michael R. Heithaus

College of Arts, Sciences, and Education

This thesis, written by Andres Eduardo Prieto Estrada, and entitled Water-Rock Interactions and Seasonal Hydrologic Processes in Constructed Everglades Tree Islands, having been approved in respect to style and intellectual content, is referred to you for judgement.

We have read this thesis and recommend that it be approved.

Leonard J. Scinto

Florentin J. Maurrasse

René M. Price, Major Professor

Date of Defense: July 5, 2016

The thesis of Andres Eduardo Prieto Estrada is approved.

Dean Michael R. Heithaus College of Arts, Sciences, and Education

Andrés G. Gil

Vice President for Research and Economic Development and Dean of the University Graduate School

Florida International University, 2016 


\section{ACKNOWLEDGMENTS}

I especially thank Dr. René Price for providing me with an opportunity to work in her Laboratory and introducing me to the field of hydrogeochemistry. Her academic guidance and support were essential throughout my graduate career and the completion of this project. I also want to thank my committee members, Dr. Leonard Scinto and Dr. Florentin Maurrasse, for dedicating part of their time in providing insightful orientation that allowed me to come through a number of multidisciplinary challenges. Another individual whom I would like to thank is Edward Linden, for patiently teaching me how to run all the lab equipment and providing useful advice.

A project like this one, involving intensive field work, required the contribution of many people to whom I am very grateful. I thank Joshua Allen, because his technical expertise was key to solve many issues with field and lab equipment. My gratitude also goes to the following individuals: Dillon Reio, Kalli Unthank, and Paul Kuhn, for helping with field and lab work. Diana Johnson from the Soil/Sediment Biogeochemistry Laboratory at FIU was of great help in analyzing my soil samples. The work of the LILA team, including Eric Cline, Dr. Thomas Dreschel, and Brad Schonhoff, was crucial to keep "the Everglades living laboratory" alive. This project was possible thanks to the funding provided by the South Florida Water Management District, and to the space and facilities provided by the Loxahatchee National Wildlife Refuge.

Finally, special thanks also go to my parents, Ramon Prieto and Norka Estrada, because without them I would not have reached where I am today. Their encouragement has been vital throughout this academic endeavor. Thank you for the support. 
ABSTRACT OF THE THESIS

\title{
WATER-ROCK INTERACTIONS AND SEASONAL HYDROLOGIC PROCESSES IN CONSTRUCTED EVERGLADES TREE ISLANDS
}

By

\author{
Andres Eduardo Prieto Estrada \\ Florida International University, 2016 \\ Miami Florida \\ Professor René M. Price, Major Professor
}

The decline of tree islands in the freshwater-Everglades wetland because of hydrologic manipulation, has compromised valuable ecosystem services. Although the role of tree islands in maintaining freshwater quality stems largely from evapotranspiration processes, fundamental questions remain about the effects of different geologic materials on their hydrogeochemical functioning. To reduce this uncertainty, the lithological composition of a set of man-made tree islands was investigated coupled with long-term hydrologic and hydrochemical data. Key results indicate that limestone substrates and peat substrates with elevated proportions of sand, facilitated surface water-groundwater interactions and mineral dissolution. However, limestone-based islands were more effective in lowering the water table and concentrating solutes in response to evapotranspiration during low surface water stages. Additionally, the peat substrate of an island with low sand content favored the thermodynamic conditions for calcite accumulation in the phreatic zone, while phosphorus concentrations in the groundwater were associated with the breakdown of organic matter. 


\section{TABLE OF CONTENTS}

CHAPTER

PAGE

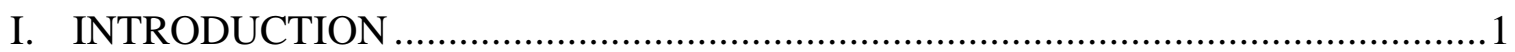

II. METHODS

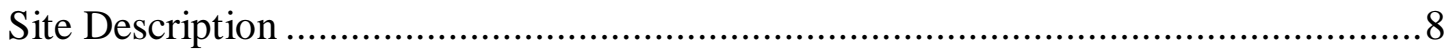

Field Sampling and Monitoring........................................................................

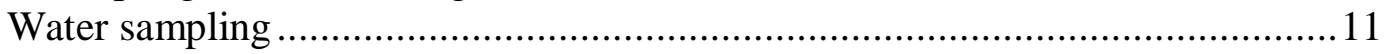

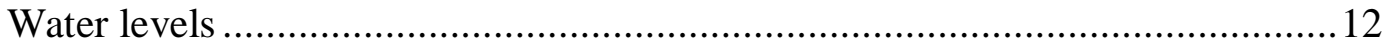

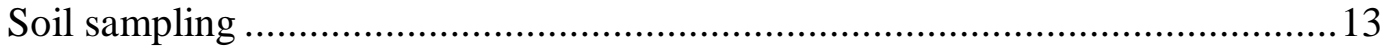

Laboratory Analyses and Hydrogeochemical Modeling ...........................................14

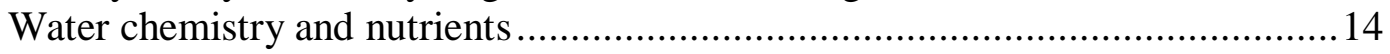

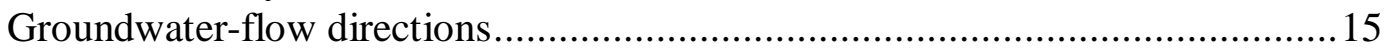

Speciation-solubility modeling and inverse (mass-balance) modeling..................16

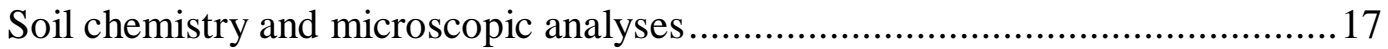

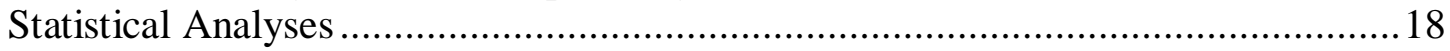

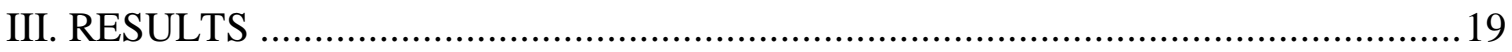

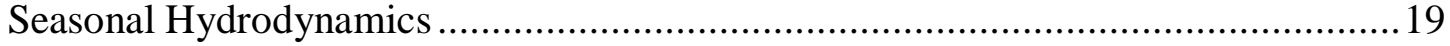

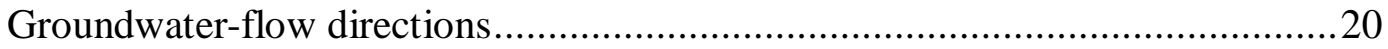

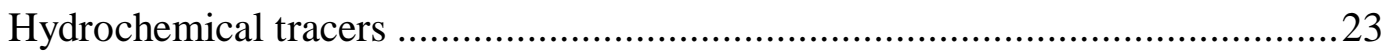

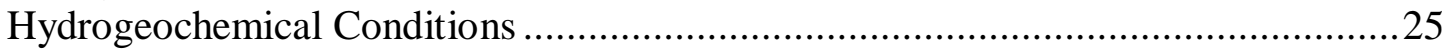

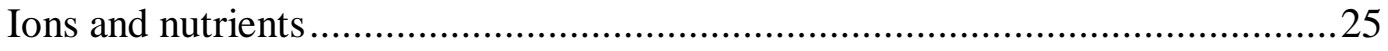

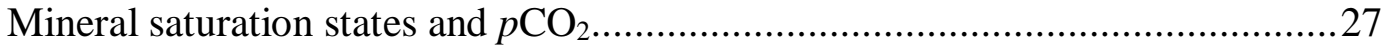

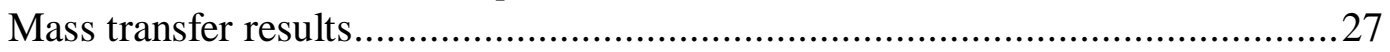

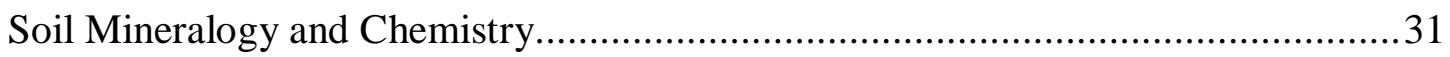

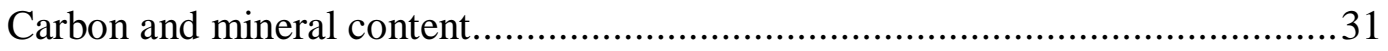

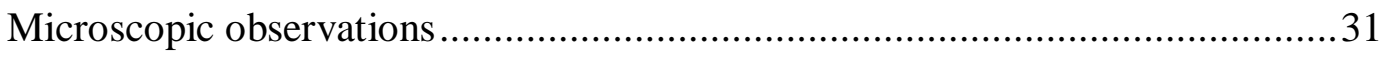

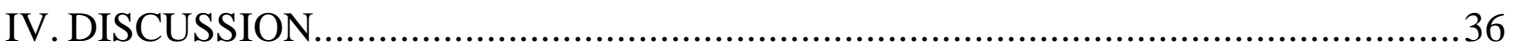

Driving Mechanisms of Seasonal Hydrologic Processes..........................................36

Influence of evapotranspiration on groundwater flow and solute transport...........36

Influence of lithology on groundwater flow and solute transport .........................38

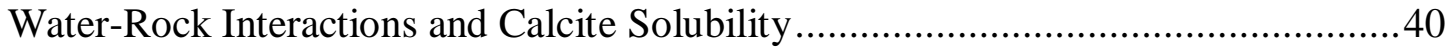

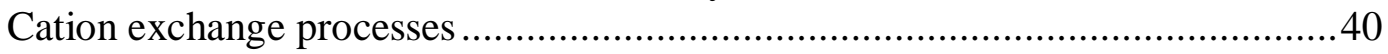

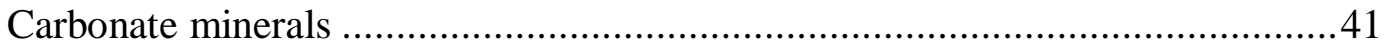

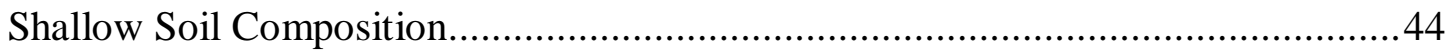

Implications on Biogeochemical Processes and Limitations .....................................46

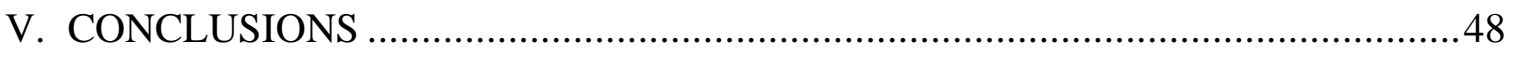

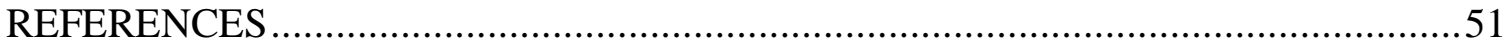


APPENDICES. 


\section{LIST OF FIGURES}

FIGURE

PAGE

1. Map of south Florida showing the major components of the Everglades (adapted from FCE LTER, 2000)

2. Map showing the location of the LILA facility in south Florida (adapted from Aich et al., 2011).

3. A) Schematic cartoon depicting the main landscape components of the freshwaterEverglades wetland (adapted from National Research Council, 2003). B) Schematic cartoon depicting the LILA macrocosms (adapted from Dreschel et al., 2010)

4. Location of the wells sampled for water chemistry and location of wells with pressure transducers in the LILA macrocosms

5. Schematic diagram showing the distribution of piezometers monitoring the groundwater levels across the eastern macrocosms at LILA

6. Hydrograph showing the surface water stages in the LILA macrocosms from October 2013 until October 2015. The timing of the water sampling events and the ground surface elevation of the tree islands, ridges, and sloughs are included. Elevation is given in meters relative to NGVD-29.

7. Monthly-averaged directions of groundwater flow (arrowed lines) and water-table elevations (continuous blue lines) across two macrocosms containing peat-based tree islands: A) M2E (October 2014); B) M2E (May 2015); C) M3E (October 2014); D) M3E (May 2015). The dashed lines represent the ground-surface elevation and the vertical lines indicate monitoring wells

8. Monthly-averaged directions of groundwater flow (arrowed lines) and water-table elevations (continuous blue lines) across two macrocosms containing limestonecore tree islands: A) M1E (October 2014); B) M1E (May 2015); C) M4E (October 2014); D) M4E (May 2015). The dashed lines represent the ground-surface elevation and the vertical lines indicate monitoring wells

9. Time-series of: A) $\delta^{18} \mathrm{O}$ enrichment B) $\mathrm{Cl}^{-}$, C) $\mathrm{Ca}^{2+}$, D) TOC, and E) TP concentrations in water samples collected at different sites. The vertical bars represent one standard error

10. Significant linear relationships between concentrations of $\mathrm{A}$ ) $\mathrm{TP}$ and $\mathrm{B}$ ) $\mathrm{Cl}^{-}$with TOC concentrations in the peat-center groundwater 
11. Comparisons of A) $\mathrm{Ca}^{2+}$, B) $\mathrm{HCO}_{3}^{-}$, and C) $\mathrm{Na}^{+}$concentrations with $\mathrm{Cl}^{-}$in water samples.....

12. Seasonal and locational variability of saturation indices with respect to calcite. A) October (wet seasons) and B) May (dry seasons). The circle and asterisk marks represent mild and extreme outliers, respectively. The dashed horizontal lines indicate equilibrium with respect to calcite

13. Vertical profiles showing concentrations of total carbon (TC), total inorganic carbon (TIC), and mineral residue in the soils of three peat-based tree islands. A) M1WA and B) M1WB are two soil cores collected from the M1W tree island. C) M2EA and D) M2EB are two soil cores collected from the M2E tree island. E) M3EA and F) M3EB are two soil cores collected from the M3E tree island. Concentrations of TC/TIC are expressed in $\mathrm{mg} / \mathrm{g}$ and mineral residue is expressed in percent of dry weight (dw\%) soil. The blue horizontal lines represent the water table below the center of the islands in May 2015, when the samples were collected (refer to Figures 7B \& 7D)

14. Photomicrographs of soil samples taken through a binocular microscope. A) Loxahatchee peat with low amounts of quartz containing gastropod shells. B) Loxahatchee peat with high amounts of quartz containing a few aggregates of quartz grains cemented with $\mathrm{CaCO}_{3}$. C) Mineral residue with high TIC concentrations showing remnant forms of gastropod shells. D) Mineral residue with low TIC concentrations mainly consisting of quartz. E) Freshwater-gastropod shells. E) Aggregate of quartz grains cemented with $\mathrm{CaCO}_{3}$ (the black lines are 1 $\mathrm{mm}$ apart). The metal bar used for scale in photomicrographs A through $\mathrm{E}$ is $1 \mathrm{~mm}$ wide

15. Photomicrographs of smear slides taken through a petrographic microscope. A), B), and C) Quartz grains embedded in isopachous-micritic cement with organic-matter coatings (cross polarized light). D) and F) Freshwater-sponge spicules with dissolution pits (plane polarized light). E) Freshwater-sponge spicule without dissolution pits (plane polarized light).

16. Seasonally-averaged $\mathrm{Cl}^{-}$concentrations and $\delta^{18} \mathrm{O}$ enrichment of water samples collected at different sites during the study period in: A) May (Dry Season) and B) October (Wet Season). Error bars represent standard errors. 


\section{ABBREVIATIONS AND ACRONYMS}

CEC

CERP

$\delta^{18} \mathrm{O}$

FIU

GW

IAP

IS

$\mathrm{K}_{\mathrm{sp}}$

LILA

LNWR

LOI

M1E

M1E4

M1E5

M1W

M1W5

M1W5 Shallow

M1W8 Deep

M2E

M2E4

M2E5
Cation Exchange Capacity

Comprehensive Everglades Restoration Plan

Ratio of Stable Isotopes Oxygen-18 and Oxygen-16

Florida International University

Groundwater

Ion Activity Product

Ionic Strength

Solubility Product Constant

Loxahatchee Impoundment Landscape Assessment

Loxahatchee National Wildlife Refuge

Loss on Ignition

Eastern Tree Island in Macrocosm 1

Southern Edge Well of Eastern Tree Island in Macrocosm 1

Center Well of Eastern Tree Island in Macrocosm 1

Western Tree Island in Macrocosm 1

Center Well of Western Tree Island in Macrocosm 1

Shallow Well of Western Tree Island in Macrocosm 1

Deep Well of Western Tree Island in Macrocosm 1

Eastern Tree Island in Macrocosm 2

Southern Edge Well of Eastern Tree Island in Macrocosm 2

Center Well of Eastern Tree Island in Macrocosm 2 
M3E

M3E4

M3E5

M3E8 Deep

M3E10S

M4E

M4W

NGDV29

$p \mathrm{CO}_{2}$

SRP

SERC

SI

SFWMD

TIC

TOC

$\mathrm{TP}$

WCA

YPB
Eastern Tree Island in Macrocosm 3

Southern Edge Well of Eastern Tree Island in Macrocosm 3

Center Well of Eastern Tree Island in Macrocosm 3

Deep Well of Eastern Tree Island in Macrocosm 3

Eastern Slough Well of Macrocosm 3

Eastern Tree Island in Macrocosm 4

Western Tree Island in Macrocosm 4

National Geodetic Vertical Datum of 1929

Partial Pressure of Carbon Dioxide

Soluble Reactive Phosphorus

Southeast Environmental Research Center

Saturation Index

South Florida Water Management District

Total Inorganic Carbon

Total Organic Carbon

Total Phosphorus

Water Conservation Area

Years Before Present 


\section{INTRODUCTION}

Some of the vital ecosystem services provided by the freshwater-Everglades wetland, including water quality, carbon storage, and nutrient cycling, result from the complex biogeochemical interplay between its distinct geomorphological features; namely, sloughs, sawgrass ridges, and tree islands (Maltby \& Dugan, 1994; Wetzel et al., 2011). Despite representing only $2 \%$ of the Everglades landscape, tree islands support the health of the ecosystem by providing unique habitats for a variety of animal and plant species, and by acting as biogeochemical hot spots (Gleason \& Stone, 1994; Wetzel et al., 2005, 2009, 2011). Furthermore, water-management practices that helped settle the population of south Florida, including the implementation of levees and large-scale pumps, water drainage by canals, and compartmentalization in water conservation areas (WCA's) 1, 2 and 3 (Figure 1), modified the natural hydrologic flow in the Everglades (Light \& Dineen, 1994; Schilling et al., 2013). This hydrologic modification resulted in a degradation of the landscape pattern, and a decrease of tree-island areas over the past century as a result of increased fire frequency and intensity or drowning of the trees (Sklar \& van der Valk, 2002). Approximately 90\% and 60\% of tree islands have disappeared in WCA2 and WCA3, respectively, compromising valuable ecosystem services (Davis et al., 1994; Patterson \& Finck, 1999; Larsen \& Harvey, 2010).

Most of the remaining tree islands are located in the western edge of WCA3, the Loxahatchee National Wildlife Refuge in the northern Everglades (WCA1), and in Shark River Slough (Figure 1) in the southern Everglades (Wetzel et al., 2005). Established theories of tree-island formation suggest that small and rounded tree islands in the northern Everglades (WCA1 and northern WCA2), also known as "battery" islands, 
formed about 1300 YBP as woody plants effectively colonized floating masses of mixed water lily-sawgrass peat (Loxahatchee peat), without the involvement of a hydrologic mechanism (Gleason \& Stone, 1994). Conversely, large and elongated "fixed" tree islands in the southern Everglades formed along the direction of water flow on the relict topography of the mineral and sediment substrate, with limestone or sand mounds underlying the peat soils (Craighead, 1974; Gleason et al., 1974). Moreover, in central Shark River Slough, a series of archaeological excavations revealed the presence of carbonate layers with thicknesses of 50 to $70 \mathrm{~cm}$ situated at depths of 25 to $50 \mathrm{~cm}$ below the soil surface, within the peaty soils of 20 large tree islands (Schwadron, 2006; Coultas et al., 2008). The original environmental conditions and the depositional and cementation processes under which such hardened layers formed have not been fully determined (Graf et al., 2008).

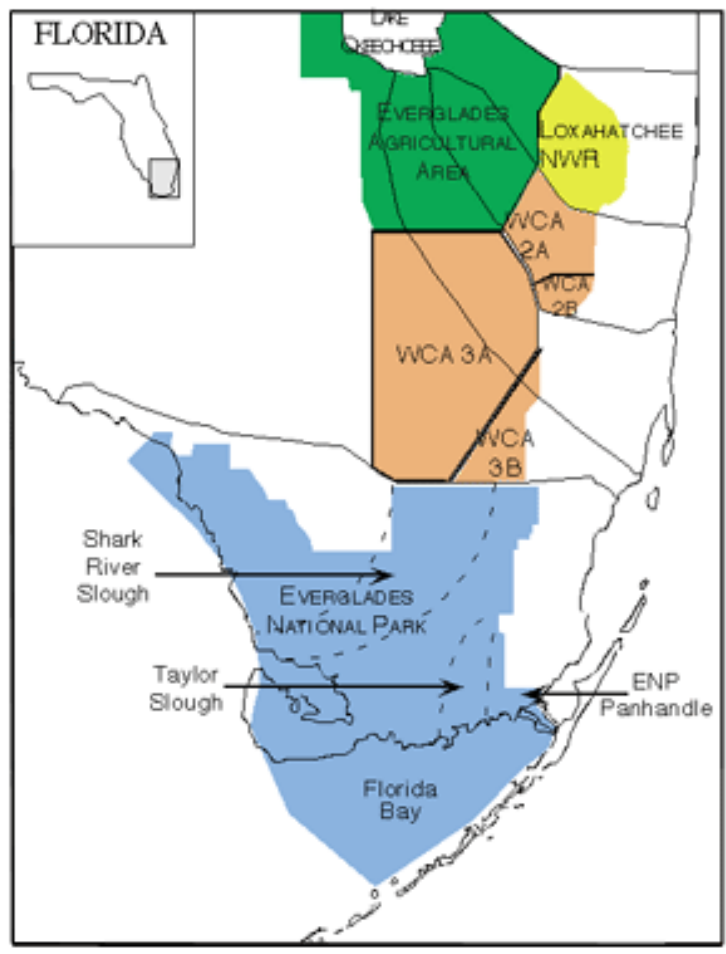

Figure 1. Map of south Florida showing the major components of the Everglades (adapted from FCE LTER, 2000). 
Calcium carbonate layers, known as calcrete or caliche, can develop in areas near the soil surface, such as seasonal wetlands, where vadose and shallow phreatic groundwaters are saturated with calcium carbonate (Wright, 2007). Groundwater saturation with calcium carbonate $\left(\mathrm{CaCO}_{3}\right)$ can result in calcite accumulation within soil profiles, sediments, and bedrock, forming a hardened layer (Wright, 2007; Alonso-Zarza $\&$ Wright, 2010). The introduction of $\mathrm{CaCO}_{3}$ into the soil can occur from cementation, displacement, and/or replacement processes (Wright, 2007; Alonso-Zarza \& Wright, 2010). Displacive mineral growth is the process that mostly occurs in non-carbonate materials, including unlithified sediments, generally within $1 \mathrm{~m}$ of the surface, because calcite $\left(\mathrm{CaCO}_{3}\right)$ is unable to form adhesive bonds with non-carbonate grains (Wright, 2007; Alonso-Zarza \& Wright, 2010; Armenteros, 2010).

Some of the main factors that control groundwater saturation with respect to $\mathrm{CaCO}_{3}$ include $\mathrm{Ca}^{2+}$ concentration, partial pressure of carbon dioxide $\left(p \mathrm{CO}_{2}\right)$, and temperature; all of which affect $\mathrm{CaCO}_{3}$ solubility (Langmuir, 1997). An increase in soil temperature, a decrease in $p \mathrm{CO}_{2}$, and an increase in $\mathrm{Ca}^{2+}$ concentrations can lead to the precipitation of $\mathrm{CaCO}_{3}$ from a solution initially at thermodynamic equilibrium (Langmuir, 1997; Meyer et al, 2014). These processes are frequently regulated by vegetation through evapotranspiration rates and seasonally-variable root water uptake (Meyer et al, 2014). Essentially, phreatophytic plants can induce chemical precipitation of calcretes from groundwater in the capillary fringe above the water-table and around the rooting zone under appropriate thermodynamic conditions (Alonso-Zarza \& Wright, 2010; Meyer et al, 2014). 
Several studies conducted in a variety of environments around the world have described evapotranspiration effects on groundwater that result in mineral precipitation within soils through different mechanisms. For example, in south-western Australia, the vegetation assembled on coastal dunes contributes to the ongoing formation of genetically different, but closely related types of calcretes through root water uptake strategies associated with seasonal evapotranspiration. Namely, a rhizoconcretionary calcrete type forms by $\mathrm{CaCO}_{3}$ precipitation around the roots after phreatophyte plants use the pellicular water of the vadose zone, while mottled and massive calcrete types are developed as the pellicular water that is not taken by plants evaporates, leaving an interstitial $\mathrm{CaCO}_{3}$ precipitate (Semeniuk \& Meagher, 1981). In peat-bog deposits in central-east Spain, plant roots contribute to the bio-induced precipitation of carbonate nodules forming caliches (López-Buendía et al., 2007). In the Mkuze freshwater-wetland system in South Africa, plants exclude many solutes ( $\mathrm{Ca}, \mathrm{Mg}$, and $\mathrm{Si}$ ) in excess to their needs from the water they take up through their roots, driving the chemical sedimentation of $\mathrm{CaCO}_{3}$, amorphous silica, and Fe-smectite (Humphries et al., 2010, 2011). In the Okavango Delta, Botswana, the elevated transpiration rate of trees growing on islands establishes a concentric groundwater-flow pattern from the surrounding swamps towards the center of the islands, where groundwater salinity steadily increases inducing the chemical precipitation of calcite and silica (McCarthy et al., 2012). Additionally, the salinity increase in the groundwater beneath the clayey soils of those islands, triggers a process of density-driven groundwater flow transporting solutes downward into the deeper aquifer layers, where saline groundwater accumulates within sand layers 
contributing to the salt balance of the freshwater-wetland ecosystem (Bauer-Gottwein et al., 2007; Ramberg \& Wolski, 2008).

Seasonal cycles of precipitation and dissolution of carbonate minerals within soils and sediments are also regulated by the position of the water table. For example, the boundary between a carbonate bearing surface zone and an underlying carbonate depleted zone in a calcareous fen in Minnesota, is affected by a critical level of the water table relative to the peat surface, above which precipitation dominates and below which dissolution dominates. Because carbonate solubility is sensitive to small changes in water chemistry, caused by variable and reversible exchanges of $\mathrm{CO}_{2}$ and water through evaporation and rainfall, carbonate precipitation and dissolution are similarly variable and reversible (Almendinger \& Leete, 1998). The solubility of carbonate minerals in water can be written in terms of $\mathrm{CO}_{2}$ or $\mathrm{H}^{+}$, with $\mathrm{CO}_{2}$ being the main source of acidity in most natural waters (Langmuir, 1997). Namely,

$$
\begin{gathered}
\mathrm{CaCO}_{3}+\mathrm{CO}_{2}(\mathrm{~g})+\mathrm{H}_{2} \mathrm{O}=\mathrm{Ca}^{2+}+2 \mathrm{HCO}_{3}^{-} \\
\mathrm{CaCO}_{3}+\mathrm{H}^{+}=\mathrm{Ca}^{2+}+\mathrm{HCO}_{3}^{-}
\end{gathered}
$$

Similarly, rising water levels associated with increased rainfall at the beginning of the wet season in Satinleaf Tree Island, located in Shark Slough in the southern Everglades (Figure 1), solubilize the salts that were accumulated during the preceding dry season in the vadose zone through root water uptake and ion-exclusion mechanisms, increasing the ionic strength (IS) of the groundwater (Sullivan et al., 2014b). Groundwater with elevated IS and supersaturated with respect to $\mathrm{CaCO}_{3}$ suggest a potential for calcite precipitation within the soils of tree islands in the Everglades, which in turn, could contribute to soil 
accretion rates on time scales of centuries to millennia (Sullivan et al., 2011, 2014a, 2014b, 2016).

Understanding mechanisms of soil formation and nutrient sequestration is essential to manage and restore a patterned wetland such as the Everglades (Wetzel et al., 2005; Stofella et al., 2010). In the Everglades tree islands, processes of soil accretion include litter-biomass production, a fraction of which gets incorporated into the soil surface (Rodriguez et al., 2014). In turn, this process is driven by the convergence of limiting resources, particularly phosphorus $(\mathrm{P})$, and produces a positive feedback loop which allows for a greater capture of resources within the tree islands, contributing to the oligotrophic conditions of the freshwater ecosystem (Wetzel et al., 2009; Rodriguez et al., 2014). Historically, approximately $67 \%$ of the P entering the Everglades was sequestered in the carbonate-rich soils of the tree islands (Wetzel et al., 2009, 2011). Whether certain mechanisms of $\mathrm{P}$ accumulation in tree islands, such as guano deposition by wading birds for centuries (Orem et al., 2002), is a more significant contributor than evapotranspiration-driven groundwater flux, remains uncertain (Larsen et al., 2011). Uncertainties also remain about the potential for mineral formation and soil accretion by an evapotranspiration mechanism.

Characterizing the hydrogeochemical conditions under which tree islands develop their natural functions, becomes necessary to maintain the health of the Everglades freshwater ecosystem, as they were developed naturally through centuries on different geologic substrates. The goal of this investigation consists in understanding how different geologic materials and seasonal evapotranspiration influence groundwater flow and water-rock interaction processes within a set of constructed Everglades tree islands. On 
the basis of previous studies conducted both in man-made and natural Everglades tree islands, two main hypotheses were tested: (1) seasonal evapotranspiration regulates the concentrations of dissolved major ions and nutrients, $p \mathrm{CO}_{2}$, and saturation indices with respect to $\mathrm{CaCO}_{3}$ in the groundwater beneath the tree islands, and (2), calcite precipitates in the capillary fringe above the water table during the dry season, forming a groundwater calcrete within the peat soils of the tree islands. To accomplish these objectives and test the formulated hypotheses, this project focused on analyzing and modeling long-term hydrogeological data, including water levels and water chemistry, obtained from a largescale geomorphological model of the freshwater-Everglades wetland. Additionally, the chemical and mineralogical composition of soil samples collected from tree islands at the same locality were characterized. The results of this investigation provide insights into the hydrogeochemical functioning of man-made tree islands, supporting the ongoing restoration efforts of tree islands in the Everglades freshwater ecosystem. 


\section{METHODS}

\section{Site Description}

This project was conducted at the Loxahatchee Impoundment Landscape Assessment (LILA) facility, located at the Arthur R. Marshall Loxahatchee National Wildlife Refuge (LNWR), Boynton Beach, FL, USA (Figure 2). LILA was constructed between 2002 and 2003 as a large-scale physical model of the freshwater-Everglades wetland (Figures $3 \& 4$ ), including tree islands, sawgrass ridges, and sloughs (Stofella et al., 2011). These geomorphological features are recreated in four 8.1-ha macrocosms, each of which contains two tree islands: a peat-based island and a limestone-core island (Figure 4). The peat-based tree islands were constructed to simulate the "battery" islands in the LNWR (northern Everglades), whereas the limestone-core islands were built to mimic the "fixed" tree islands that formed on the relict limestone substrate in Shark River Slough (southern Everglades). Each island is approximately $43 \times 71 \mathrm{~m}$ in size. The top of the tree islands is approximately $1 \mathrm{~m}$ higher than the bottom of their surrounding sloughs, which were sculpted from the existing LNWR impoundments. The organic soils that were excavated to create the sloughs, were agglomerated on top of the tree islands to generate the topographic contrast, with the sawgrass ridges being the only undisturbed topographic features during the construction process of LILA (Sklar et al., 2004). The tree islands in macrocosms M1 and M4 were planted in March 2006, while the tree islands in macrocosms M2 and M3 were planted in march 2007 (Sullivan et al., 2011).

The climatic conditions at LILA are similar to those across south Florida, with distinct wet and dry seasons between June and November and December and May, respectively. The area has an annual average of $133 \mathrm{~cm}$ of precipitation (Ali et al., 2000). 
The surface-water levels in LILA are controlled to simulate the seasonal variations of the surface-water levels in the Everglades. They are maintained according to an established hydrograph with the highest levels typically occurring from September to January, flooding the tree islands, and the lowest levels occurring from April to June (Sullivan et al., 2011, 2014a, 2016). The water within LILA is managed by a large electric pump $\left(1.84 \mathrm{~m}^{3} / \mathrm{s}\right)$, a series of water control structures, and recording stage gauges, allowing researchers to manage water levels and flow rates within each macrocosm (Aich et al., 2011). The capability to manage hydrologic conditions in LILA, makes it a perfect setting to study the hydrogeochemical conditions of developing tree islands. Thus, results from LILA will contribute to reduce uncertainties about the Everglades ecosystem, as the Comprehensive Everglades Restoration Plan (CERP) progresses (Sklar et al., 2004).

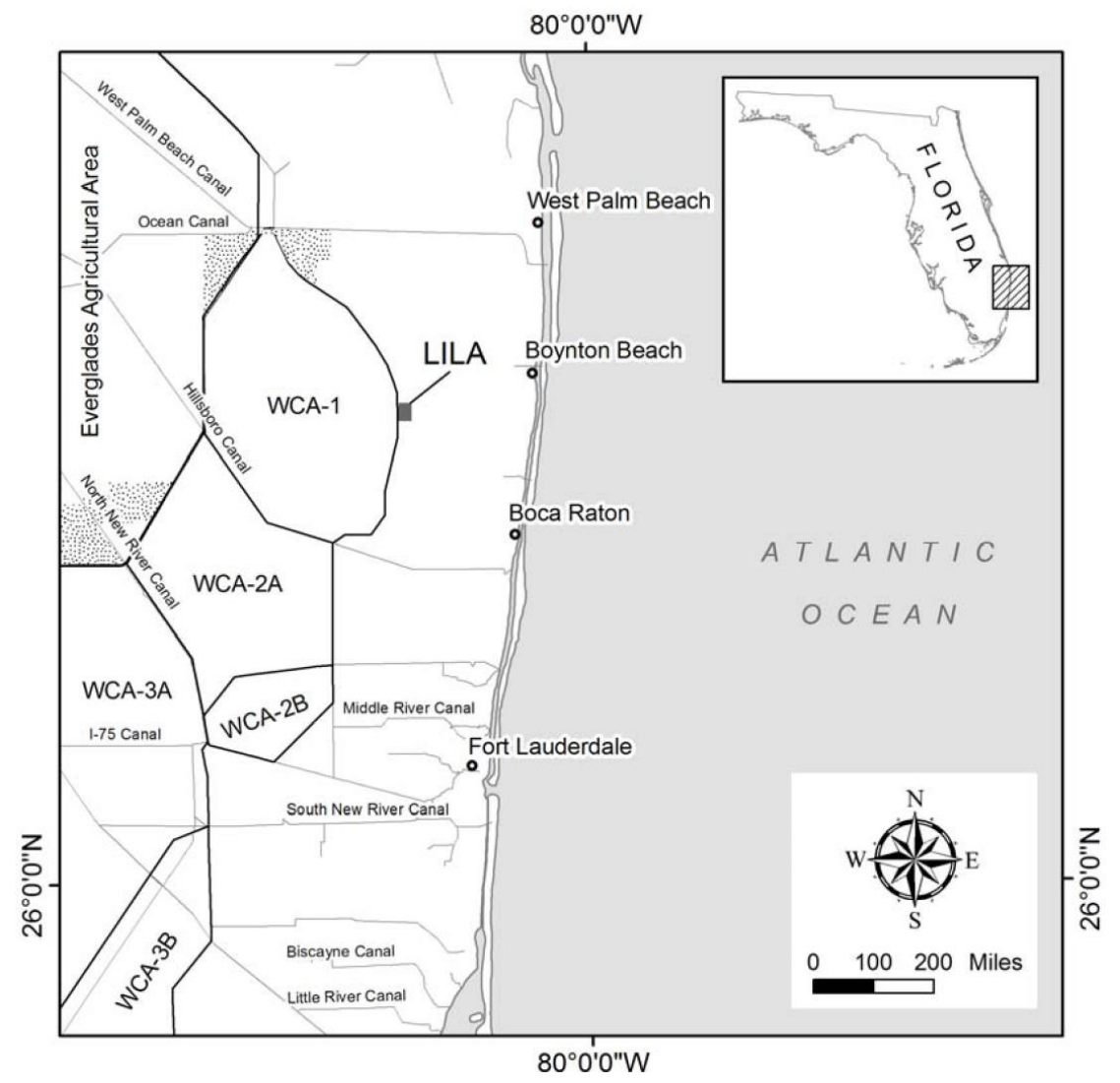

Figure 2. Map showing the location of the LILA facility in south Florida (adapted from Aich et al., 2011). 

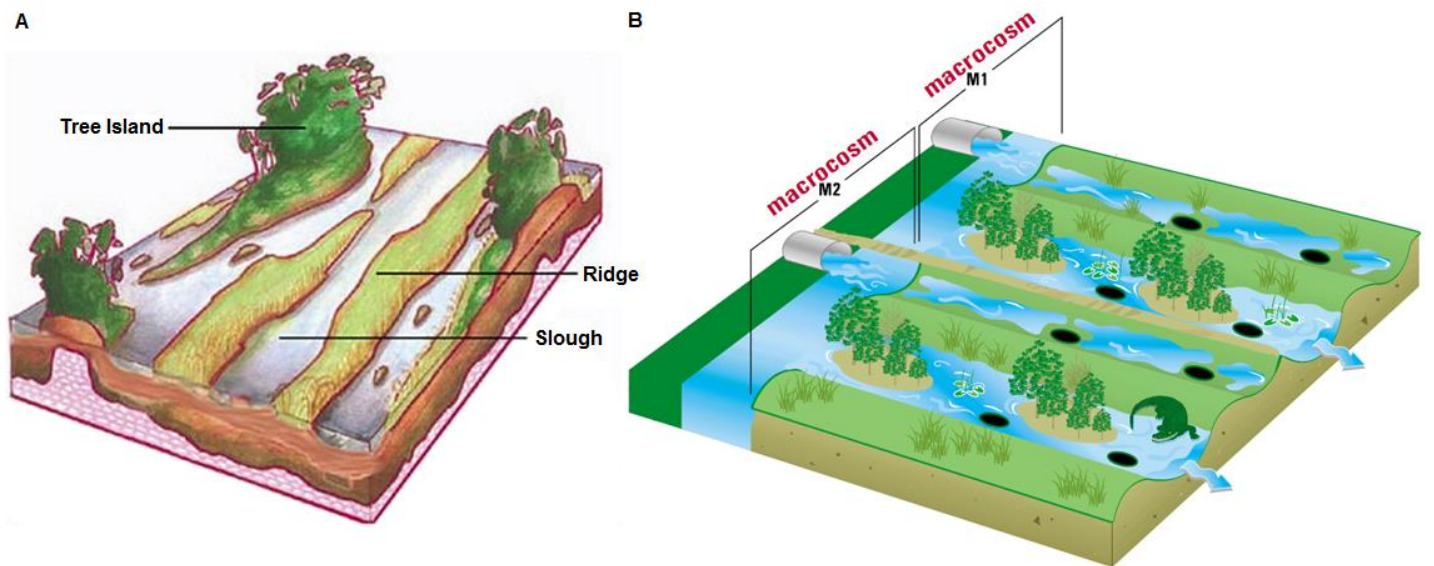

Figure 3. A) Schematic cartoon depicting the main landscape components of the freshwater-Everglades wetland (adapted from National Research Council, 2003). B) Schematic cartoon depicting the LILA macrocosms (adapted from Dreschel et al., 2010).

\section{Field Sampling and Monitoring}

The LILA facility has an extensive network of PVC-encased wells with an average depth of $1.34 \mathrm{~m}$ across the tree islands, ridges, and sloughs (Figure 4). All wells have a 50-60 cm screened interval at the bottom. This well-construction design conferred a sturdy foundation for the wells, while allowing to collect groundwater samples in contact with the peat soils and the deeper mineral substrates. The wells located on the edges of the islands are referred to as edge wells and those in the center are referred to as center wells. The center wells of the peat-based islands are referred to as peat-center wells, while the center wells of the limestone-core islands are referred to as limestonecenter wells. Each peat-based tree island has an additional well with a depth of $2 \mathrm{~m}$ referred to as peat-deep wells. The peat-based island M1W has one additional center well with a depth of $0.6 \mathrm{~m}$ referred to as peat-shallow well. (Sullivan, 2011). Groundwater sampling in the shallow, center, and deep wells in the tree island M1W (Figure 4) allowed to analyze hydrogeochemical processes within the peat soil profile. 


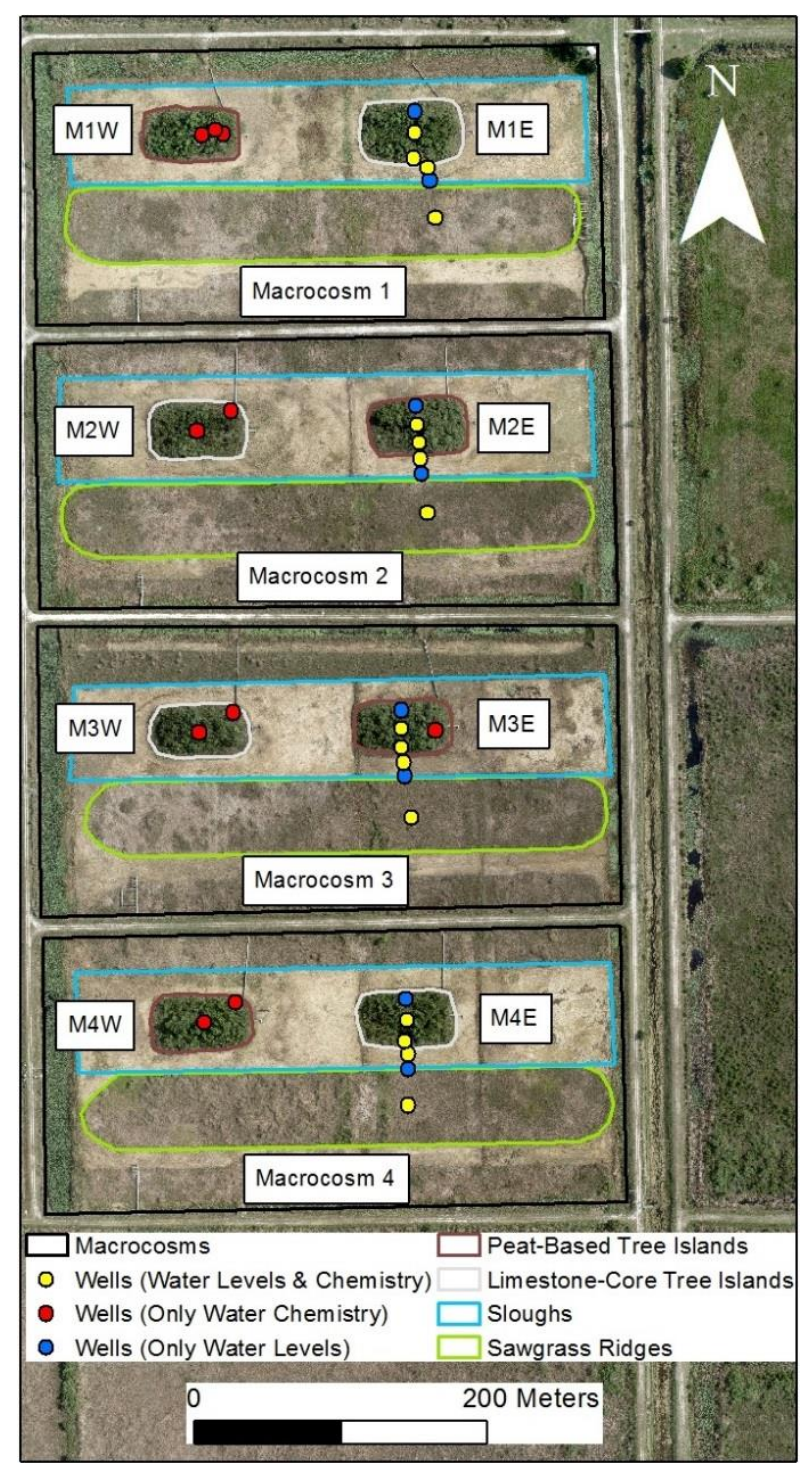

Figure 4. Location of the wells sampled for water chemistry and location of wells with pressure transducers in the LILA macrocosms.

\section{Water sampling}

A total of 27 groundwater and 8 surface-water samples were collected biannually

in October (wet season) and May (dry season) from October 2013 until October 2015. All sampling wells (Figure 4) and surface-water sites were sampled with a peristaltic pump and each well was purged of three well volumes before sampling. Temperature, conductivity, and $\mathrm{pH}$ were measured in the field using an YSI ${ }^{\mathrm{TM}}$ meter and a Thermo- 
Scientific Orion ${ }^{\mathrm{TM}} 3$-Star $\mathrm{pH}$ meter, respectively. Two filtered $(0.45 \mu \mathrm{m}$ membrane filter $)$ and two unfiltered samples were collected at each well and surface water location. A filtered and an unfiltered sample on each site were preserved with $10 \%$ hydrochloric acid ( $\mathrm{HCl})$, for cation and total phosphorus analysis, respectively. All samples were stored at 4 ${ }^{\circ} \mathrm{C}$ and transported to Florida International University (FIU).

\section{Water levels}

In-Situ Level TROLL $500^{\circledR}$ pressure transducers were deployed in two edge wells, the center, slough, and ridge wells of each eastern macrocosm, allowing for crosssectional monitoring of the water table across the recreated landscape (Figures $4 \&$ Figure 5). In addition, three pressure transducers were installed in three PVC-case structures, each one of them anchored in a slough, measuring surface-water levels in three eastern cells (M2E, M3E, and M4E). The pressure transducers were vented to the atmosphere and set to record groundwater levels every 30 minutes, with an accuracy of \pm $3.5 \mathrm{~mm}$. The elevation of the top of each groundwater well and the position of the pressure transducers were determined using standard surveying techniques, relative to the National Geodetic Vertical Datum of 1929 (NGDV29), with a \pm 3 mm level of accuracy. Data obtained since 2013 with this pressure-transducer configuration was used to model groundwater-flow directions across the eastern macrocosms at LILA.

The South Florida Water Management District (SFWMD) maintains a network of recording gauges to measure the surface-water levels at the eastern and western boundaries of each macrocosm. This information is publicly available online through the 
DBHYDRO database: http://my.sfwmd.gov/dbhydroplsql/show_dbkey_info.main_menu.

A linear interpolation between the stages was used to determine the surface-water levels along the boundaries of the eastern tree island in M1 and to fill in data gaps in the other cells when necessary.

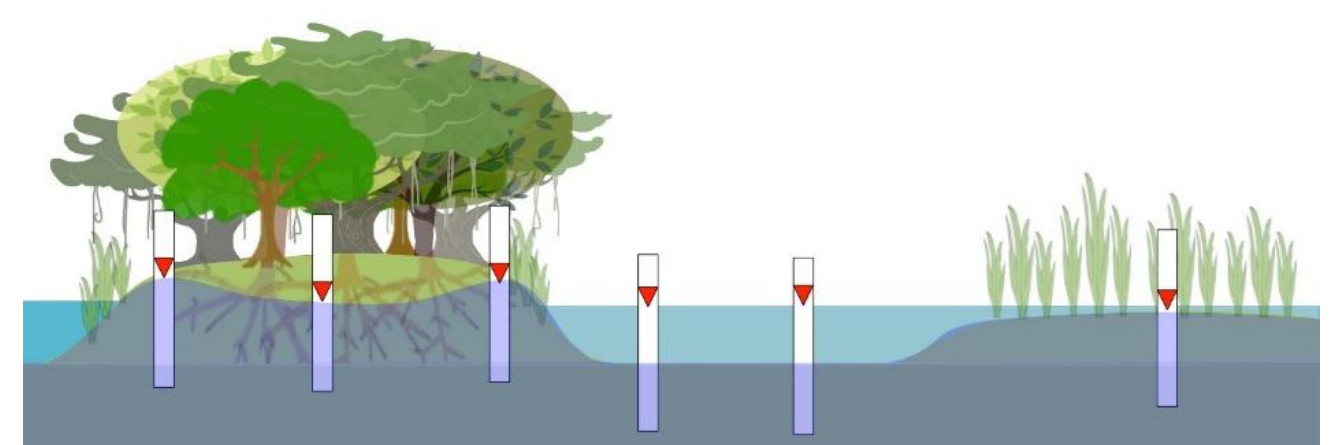

Figure 5. Schematic diagram showing the distribution of piezometers monitoring the groundwater levels across the eastern macrocosms at LILA.

\section{Soil sampling}

Soil samples were collected from three peat-based tree islands at LILA using a soil auger. These islands were chosen because their peat soils allowed hand augering to 1 meter soil depth, which corresponded approximately to the lowest observed groundwater levels in the tree islands. Eight soil cores were obtained throughout April and May 2015 to assess possible $\mathrm{CaCO}_{3}$ accumulation within the soil at the center of the islands. Two preliminary cores were collected at the center of island M2E (Figure 4) from the ground surface in section increments of $8 \mathrm{~cm}$ down to $96 \mathrm{~cm}$, for a total of 24 soil samples. In addition, three cores were obtained from the center of island M1W and three more from the center of island M3E. These soil samples were obtained in increments of $8 \mathrm{~cm}$ down to $40 \mathrm{~cm}$, in increments of $4 \mathrm{~cm}$ down to $72 \mathrm{~cm}$, and in increments of $8 \mathrm{~cm}$ down to 96 $\mathrm{cm}$, for a total of 96 samples. The island M1W was chosen for being one of the first 
islands where trees were planted (March 2006), and M3E was chosen for having the lowest groundwater levels during the study period (Figure 4).

\section{Laboratory Analyses and Hydrogeochemical Modeling}

Water chemistry and nutrients

All the unfiltered water samples preserved with $\mathrm{HCl}$ were analyzed for total phosphorus (TP) and total organic carbon (TOC) at the Southeastern Environmental Research Center Nutrient Analysis Laboratory (SERC-NAL) using an Alpkem Rapid Flow Analyzer with 2-Channel ER Detector and a Shimadzu TOC-V, respectively. Filtered $(0.45 \mu \mathrm{m})$ water samples were also analyzed for soluble reactive phosphorus $\left(\mathrm{PO}_{4}{ }^{3-}\right)$ and ammonium $\left(\mathrm{NH}_{4}{ }^{+}\right)$at the FIU Soil/Sediment Biogeochemistry Laboratory using an Alpkem 300 Series 4 Channel Rapid Flow Analyzer. Total and dissolved phosphorus and carbon concentrations in the groundwater samples were used to understand nutrient dynamics in the LILA groundwater system, in response to seasonal hydrologic processes.

All the filtered water samples were analyzed for total alkalinity and major anions (chloride $\left[\mathrm{Cl}^{-}\right]$and sulfate $\left[\mathrm{SO}_{4}{ }^{2-}\right]$ ) and cations (calcium $\left[\mathrm{Ca}^{2+}\right]$, magnesium $\left[\mathrm{Mg}^{2+}\right]$, sodium $\left[\mathrm{Na}^{+}\right]$, and potassium $\left[\mathrm{K}^{+}\right]$) at the FIU Hydrogeology Laboratory using a Brinkman Titrino ${ }^{\mathrm{TM}} 751$ Titrator and a Dionex-120 ${ }^{\mathrm{TM}}$ Ion Chromatograph, respectively. Total alkalinity was calculated as concentration of $\mathrm{HCO}_{3}{ }^{-}$by titrating $30 \mathrm{~mL}$ of water samples with $0.1 \mathrm{~N} \mathrm{HCl}$ to an inflection point closest to a pH of 2 . The charge balance of all water samples was $<5 \%$. Ion concentrations were used for hydrogeochemical modeling, including determination of mineral saturation states and geochemical reactions 
during groundwater flow. Filtered water samples were also analyzed for the stable isotopic composition of hydrogen $(\delta \mathrm{D})$ and oxygen $\left(\delta^{18} \mathrm{O}\right)$ using a LGR DTL-100 ${ }^{\mathrm{TM}}$ Liquid Water Isotope Analyzer at the FIU Hydrogeology Laboratory. The $\delta^{18} \mathrm{O}$ values were used in conjunction with $\mathrm{Cl}^{-}$concentrations as hydrochemical tracers to investigate groundwater movement.

\section{Groundwater-flow directions}

Groundwater-flow directions across the eastern macrocosms were simulated for two seasons using a finite-difference solution to the two-dimensional Laplace's equation, which states that the sum of the second order partial derivative of $h$ (hydraulic head) with respect to $x$ and $y$ (spatial variables), is zero (Wang \& Anderson, 1982).

$$
\frac{\partial^{2} h}{\partial x^{2}}+\frac{\partial^{2} h}{\partial y^{2}}=0
$$

Assumptions associated with this equation include groundwater flow through an isotropic, homogeneous aquifer under steady-state conditions (Wang \& Anderson, 1982). The rectangular domain of the mathematical model consisted in a 75-by-5 matrix representing the distribution of piezometers at LILA (Figure 5). No-flow boundaries were assigned to the left, right, and bottom boundaries of the domain. The top boundary was simulated to represent the water table across each macrocosm by applying a spline interpolation technique to the observed water levels. The water levels corresponded to the monthly-averaged values of October 2014 and May 2105; thus, the modeled groundwater-flow directions represented monthly-averaged directions of groundwater flow across the macrocosms in two different seasons. 


\section{Speciation-solubility modeling and inverse (mass-balance) modeling}

The speciation and activities of the measured ions in the water samples, including $\mathrm{HCO}_{3}{ }^{-}, \mathrm{Cl}^{-}, \mathrm{SO}_{4}{ }^{2-}, \mathrm{PO}_{4}{ }^{3-}, \mathrm{Ca}^{2+}, \mathrm{Mg}^{2+}, \mathrm{Na}^{+}$, and $\mathrm{K}^{+}$were calculated through the AquaChem software version 2014.1, using the thermodynamic database of the geochemical modeling code PHREEQC version 3.3.5 (Parkhurst \& Appelo, 2013). The partial pressure of carbon dioxide $\left(p \mathrm{CO}_{2}\right)$ and the saturation index $(\mathrm{SI})$, defined as the logarithm of the ratio of the ion-activity product, IAP, to the solubility product constant, $\mathrm{K}_{\mathrm{sp}}$ (Nordstrom \& Campbell, 2014), were calculated using the same software and database in order to determine the mineral saturation state of all the water samples.

$$
S I=\log \left[\frac{I A P}{K_{s p}}\right]
$$

Samples with SI > 0 were considered supersaturated with respect to the mineral, and mineral precipitation was expected; while samples with SI $<0$ were undersaturated with respect to the mineral, and mineral dissolution was expected (Plummer et al., 1983; Langmuir, 1997). Water samples with SI $=0$ were considered at equilibrium, with both mineral dissolution and precipitation processes expected equally. The temperature and $\mathrm{pH}$ of the water samples were also used as input parameters to AquaChem for speciationsolubility calculations.

The graphical user interface PhreeqcI version 3.3.5 for the code PHREEQC version 3.3.5 (Parkhurst \& Appelo, 2013), was used to identify the geochemical reactions that quantitatively could account for the observed water compositions along groundwater flow paths within the tree islands at LILA, in two different seasons. Because this inverse modeling technique requires the definition of all the potential reactants and products in 
the groundwater system (Plummer et al., 1983; Parkhurst et al., 1993), the following phases were considered to be present in the soils of the LILA macrocosms: calcite, dolomite $\left(\mathrm{CaMg}\left(\mathrm{CO}_{3}\right)_{2}\right.$ as a source of dissolved $\mathrm{Ca}^{2+}, \mathrm{Mg}^{2+}$, and $\left.\mathrm{HCO}_{3}{ }^{-}\right), \mathrm{CO}_{2}(\mathrm{~g})$, $\mathrm{H}_{2} \mathrm{O}(\mathrm{g})$, and cation exchange $\left(\mathrm{CaX}_{2}, \mathrm{MgX}\right.$, and $\left.\mathrm{NaX}\right)$. The calculated SI's, $p \mathrm{CO}_{2}$ values, and $\mathrm{Ca}^{2+} / \mathrm{Na}^{+}$exchange processes were used as model constraints. Cation exchange can be represented by the following equation:

$$
2 \mathrm{Na}^{+}+\mathrm{CaX}_{2}=2 \mathrm{NaX}+\mathrm{Ca}^{+2}
$$

where $\mathrm{X}$ indicates the soil exchanger. Sodium is taken up by the exchanger and $\mathrm{Ca}^{2+}$ is the released. The option for minimal model calculations was utilized to produce models containing the most essential geochemical reactions, and uncertainty limits were specified for the initial and final solutions as well as for multiple elements in each solution, which allowed for a systematic assessment of the significance of mass transfers in the resultant models (Parkhurst, 1997; Parkhurst \& Appelo, 2013). Uncertainty limits of $5 \%$ were assigned to the initial and final solutions. Additionally, because the mineralogy of the deeper soils in the macrocosms has not been investigated, and as a model simplification, the concentrations of $\mathrm{Cl}^{-}, \mathrm{K}^{+}, \mathrm{PO}_{4}{ }^{3-}$, and $\mathrm{SO}_{4}{ }^{-}$were balanced in all the geochemical simulations. Thus, mineral sources and sinks for these ions were omitted.

\section{Soil chemistry and microscopic analyses}

Total carbon (TC) and total inorganic carbon (TIC) were measured on oven-dried $\left(80^{\circ} \mathrm{C}\right)$ soil samples by the high-temperature method of dry combustion (Nelson $\&$ Sommers, 1996) using a Thermo Finnigan FlashEA ${ }^{\circledR} 1112$ Nitrogen and Carbon 
Analyzer at the FIU Soil/Sediment Biogeochemistry Laboratory. Organic matter was determined by loss-on-ignition (LOI) at $550^{\circ} \mathrm{C}$ with an accuracy of $\pm 2 \%$ (Nelson \& Sommers, 1996). These results were used to quantify the distribution of inorganic carbon and mineral content within the soils of peat-based tree islands at LILA.

For every soil core collected, six samples and their corresponding mineral content from different sampling depths were described using a binocular microscope. These observations were conducted to determine the physical characteristics of the soils, including the organic and mineral fractions, and to identify the sources of TIC. On the basis of such determinations, a number of smear slides were prepared and analyzed with a Leica DM EP polarizing microscope at the FIU's Stratigraphy Laboratory, in order to assess carbonate cementation processes in the soil samples.

\section{Statistical Analyses}

Statistical analyses were conducted using IBM ${ }^{\circledR}$ SPSS $^{\circledast}$ Statistics version 23. Two-tailed Pearson correlations were computed to determine significant linear correlations between hydrochemical constituents and geochemical parameters in the water samples grouped in categories, according to sampling location and type of tree island (peat-based or limestone-core islands). Additionally, box-and-whisker plots were generated to graphically depict the statistical distribution of the mineral saturation states of the water samples, in the wet and dry seasons, as a function of sampling location. 


\section{RESULTS}

\section{Seasonal Hydrodynamics}

The surface water levels across the macrocosms at LILA varied according to the operational hydrograph, simulating the seasonality of the Everglades (Figure 6). However, two exceptions occurred in macrocosm M1 during hydrologic reversals characterized by a rapid re-flooding and subsequent dry-down, or vice versa. These non-seasonal events took place in April 2014 and in April 2015 over four-week periods (Figure 6), and were implemented by other scientific projects in LILA. Aside from the short hydrologic reversals, the surface water levels in all the macrocosms varied similarly throughout the study period, with highest and lowest elevations in October 2014 and July 2015, respectively (Figure 6).

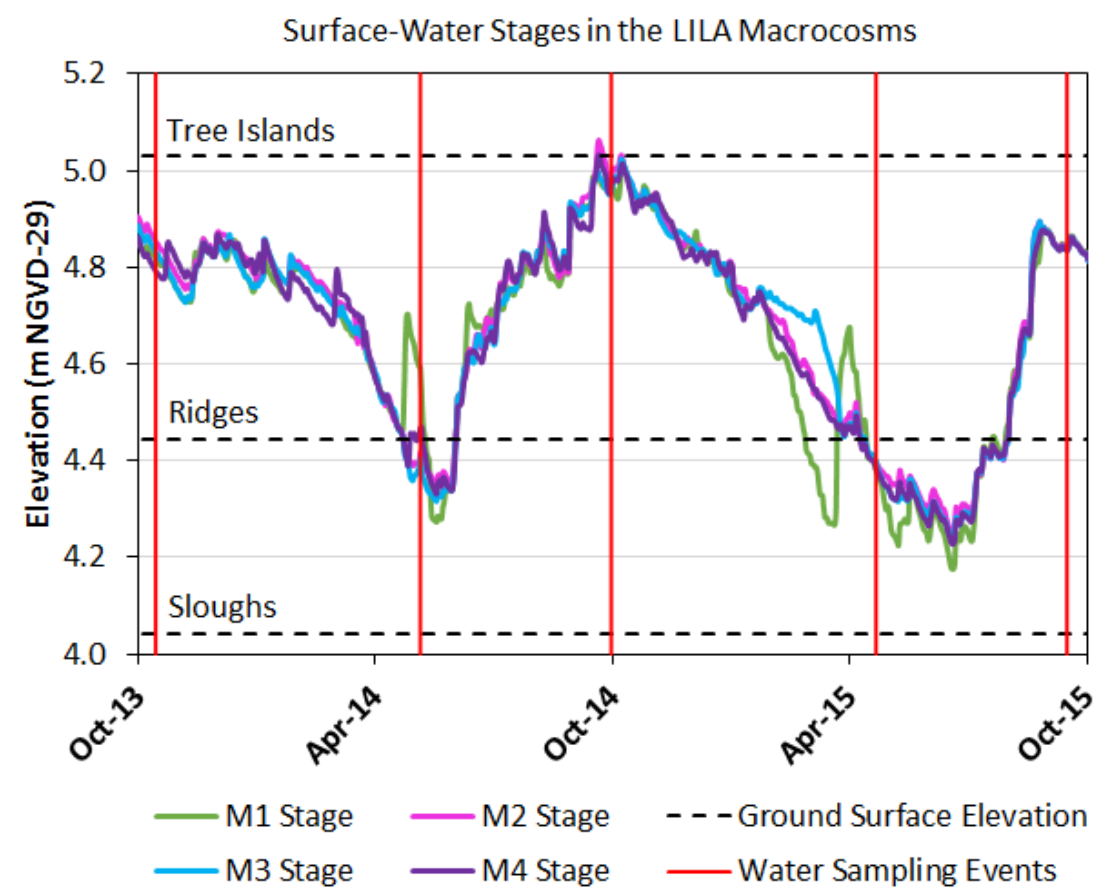

Figure 6. Hydrograph showing the surface water stages in the LILA macrocosms from October 2013 until October 2015. The timing of the water sampling events and the ground surface elevation of the tree islands, ridges, and sloughs are included. Elevation is given in meters relative to NGVD-29. 


\section{Groundwater-flow directions}

Groundwater-flow directions were markedly different the peat-based tree islands M2E and M3E (Figure 7). The seasonal fluctuation of the water table was homogeneous across the M2E tree island, with the lowest hydraulic gradient amongst all macrocosms and a predominantly horizontal direction of groundwater flow (Figures 7A \& 7B). During the wet season (October), when the peat-based tree island M2E was flooded, groundwater flowed from the center of the island towards the slough and the ridge (Figure 7A). In the dry season (May), groundwater flow in M2E was from the ridge towards the slough, from the slough towards the southern edge of the island, and from the center of the island towards its northern edge (Figure 7B). Moreover, a depression in the water table persisted throughout the study period in the center of the peat-based tree island M3E. Higher hydraulic gradients were observed in M3E during the dry season resulting in sloughgroundwater flow into the center of the island (Figures 7C \& 7D).

In the limestone-core tree islands M1E and M4E, groundwater-flow directions were similar during the dry season, but differed from each other during the wet season (Figure 8). The water table at M1E was continuously depressed below the center of the limestone-core island throughout the study period, with higher hydraulic gradients during the dry season (Figures 8A \& 8B). In contrast, during the wet season, groundwater in M4E flowed across the limestone-core island from its southern edge, where a hydraulic divide resulted in simultaneous groundwater discharge to the slough (Figure 8C). During the dry season, a water-table depression developed beneath the center of the M4E, with shallow groundwater from the edges and deeper slough groundwater flowing into the center of the island (Figure 8D). 

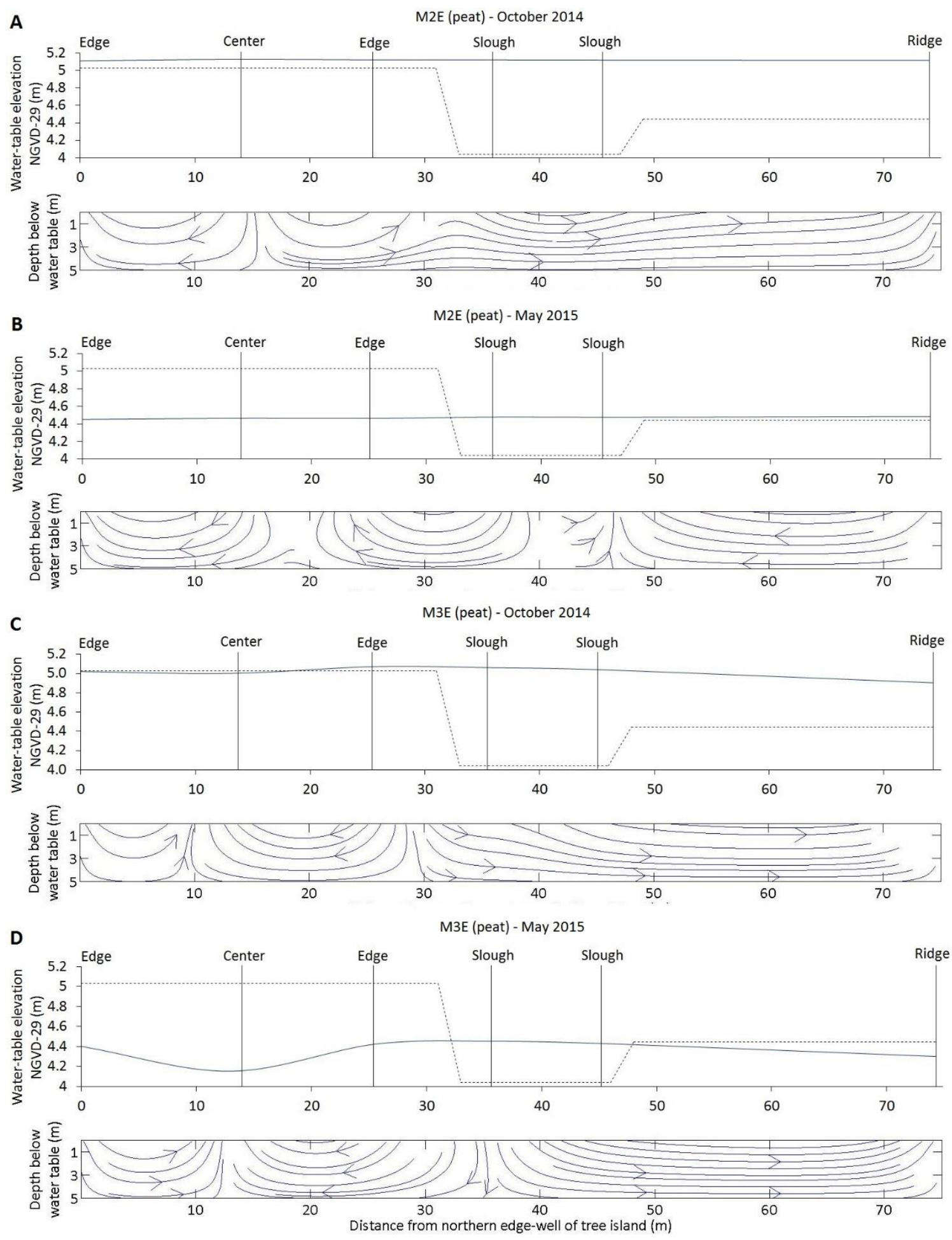

Figure 7. Monthly-averaged directions of groundwater flow (arrowed lines) and water-table elevations (continuous blue lines) across two macrocosms containing peat-based tree islands: A) M2E (October 2014); B) M2E (May 2015); C) M3E (October 2014); D) M3E (May 2015). The dashed lines represent the groundsurface elevation and the vertical lines indicate monitoring wells. 

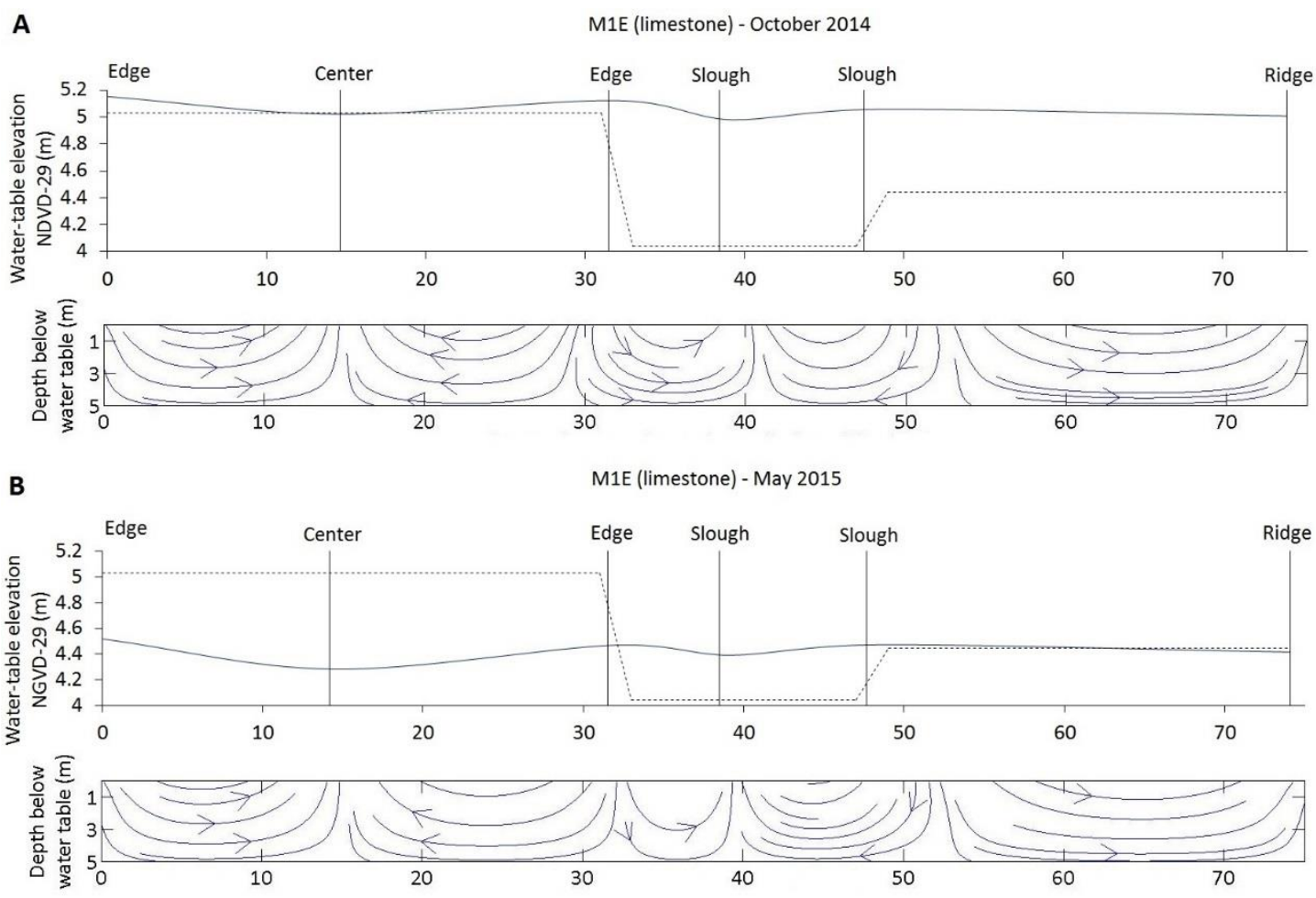

C
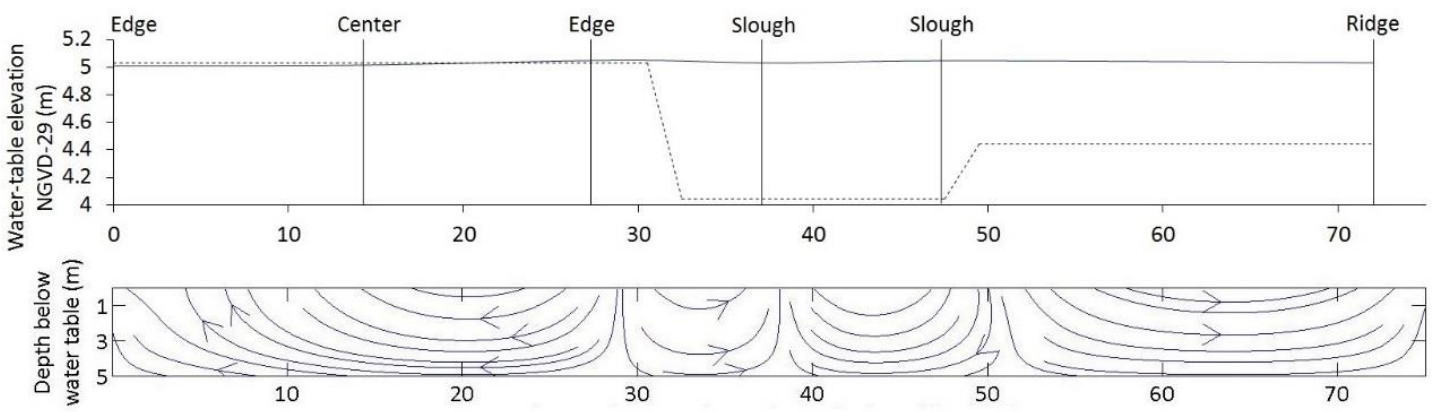

D

M4E (limestone) - May 2015
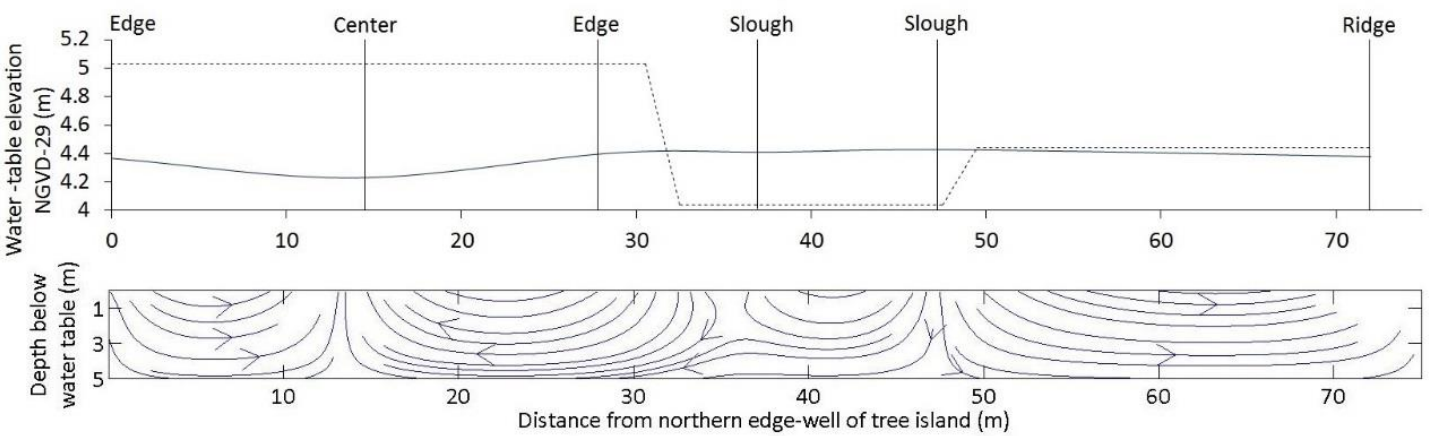

Figure 8. Monthly-averaged directions of groundwater flow (arrowed lines) and water-table elevations (continuous blue lines) across two macrocosms containing limestone-core tree islands: A) M1E (October 2014); B) M1E (May 2015); C) M4E (October 2014); D) M4E (May 2015). The dashed lines represent the ground-surface elevation and the vertical lines indicate monitoring wells. 


\section{Hydrochemical tracers}

The $\delta^{18} \mathrm{O}$ values and $\mathrm{Cl}^{-}$concentrations in the water samples collected from the tree islands fluctuated seasonally throughout the study period (Figures 9A \& 9B). In the peatbased tree islands, the values of $\delta^{18} \mathrm{O}$ enrichment were typically higher in the peat-deep groundwater, lower in the peat-center groundwater, and lowest in the peat-shallow groundwater, particularly during the wet seasons (Figure 9A). Conversely, $\mathrm{Cl}^{-}$ concentrations in the peat-based tree islands were higher in the peat-shallow, lower in the peat-deep, and lowest in the peat-center groundwater, since October 2013 (Figure 9B). Furthermore, $\mathrm{Cl}^{-}$concentrations steadily decreased in the peat-center groundwater of island M1W, approaching those in the edge groundwater (Appendix A). In the limestone-center groundwater, $\mathrm{Cl}^{-}$concentrations tended to increase throughout the study period (Figure 9B). However, $\mathrm{Cl}^{-}$concentrations in the limestone-center groundwater were generally lower compared to those in the peat-center groundwater, with the opposite case for $\delta^{18} \mathrm{O}$ enrichment (Figures 9A \& 9B).

Samples collected from the edge of the islands showed relatively stable $\mathrm{Cl}^{-}$ concentrations with very low seasonal fluctuations, as opposed to their $\delta^{18} \mathrm{O}$ values, which fluctuated seasonally (Figures 9A \& 9B). Groundwater samples collected from the ridges and from the sloughs showed negligible seasonal variations with respect to both hydrochemical tracers (Figures 9A \& 9B). Surface water followed a seasonal evaporation trend, with slightly higher $\mathrm{Cl}^{-}$concentrations and isotopic enrichment in the dry seasons, and an opposite behavior in the wet seasons (Figures 9A \& 9B). 

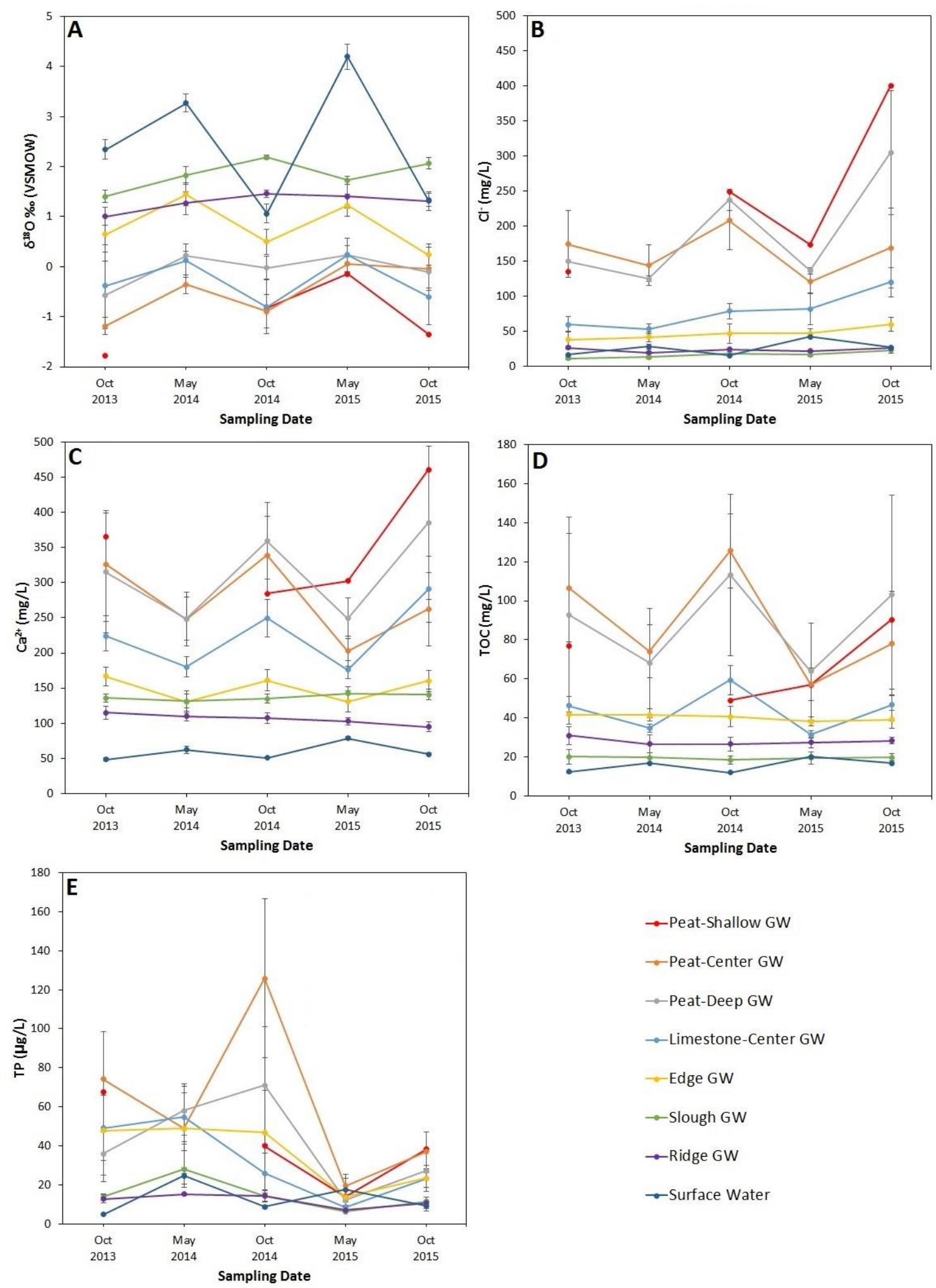

Figure 9. Time-series of: A) $\delta^{18} \mathrm{O}$ enrichment B) $\mathrm{Cl}^{-}$, C) $\mathrm{Ca}^{2+}$, D) TOC, and E) TP concentrations in water samples collected at different sites. The vertical bars represent one standard error. 


\section{Hydrogeochemical Conditions}

\section{Ions and nutrients}

Most ion and nutrient concentrations in the water samples, particularly in those obtained from the tree islands, including the peat-shallow, peat-deep, peat-center, and limestone-center wells, varied seasonally with higher and lower values in October and May, respectively (Figures 9B, 9C, 9D, \& 9E). Conversely, the nutrient and ion concentrations in the slough, ridge, and occasionally the edge wells, were relatively stable throughout the study period (Figures 9B, 9C, 9D, \& 9E). The concentrations of TP in all groundwater samples followed a similar trend since October 2014, with higher and lower values in October and May, respectively (Figure 9E). The concentrations of TP in the surface water collected in the sloughs followed the opposite seasonal pattern (Figure 9E). Moreover, constituent concentrations were highest in peat-center groundwater compared to the limestone-center groundwater (Figures 9B, 9C, 9D, \& 9E).

In the peat-center groundwater, both $\mathrm{TP}$ and $\mathrm{Cl}^{-}$concentrations were significantly and linearly correlated with TOC concentrations (Figures 10A \& 10B). Furthermore, an excess in $\mathrm{Ca}^{2+}$ and $\mathrm{HCO}_{3}{ }^{-}$concentrations with respect to $\mathrm{Cl}^{-}$was observed in all the samples (Figures 11A \& 11B). Additionally, samples collected from the wells in the tree islands showed a depletion in $\mathrm{Na}^{+}$concentrations with respect to $\mathrm{Cl}^{-}$, when $\mathrm{Cl}^{-}$ concentrations exceeded 2 meq/L (Figure 11C). 

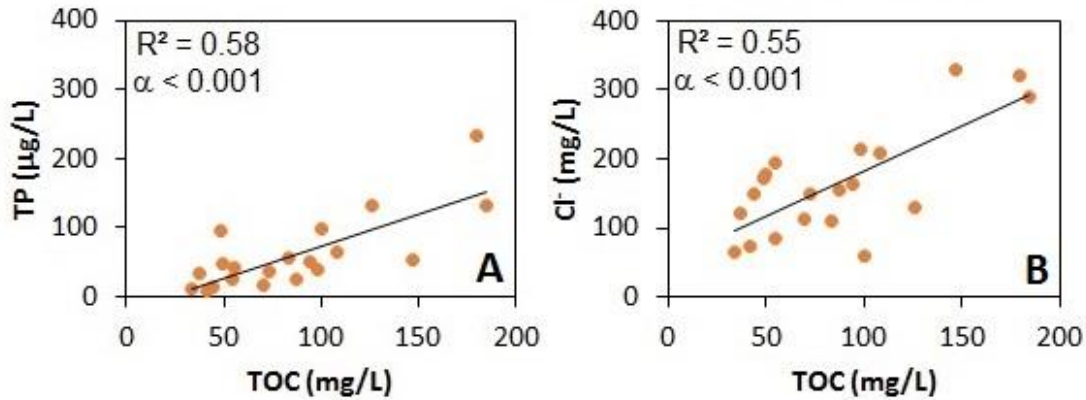

Figure 10. Significant linear relationships between concentrations of A) $\mathrm{TP}$ and $\mathrm{B}$ ) $\mathrm{Cl}^{-}$with $\mathrm{TOC}$ concentrations in the peat-center groundwater.
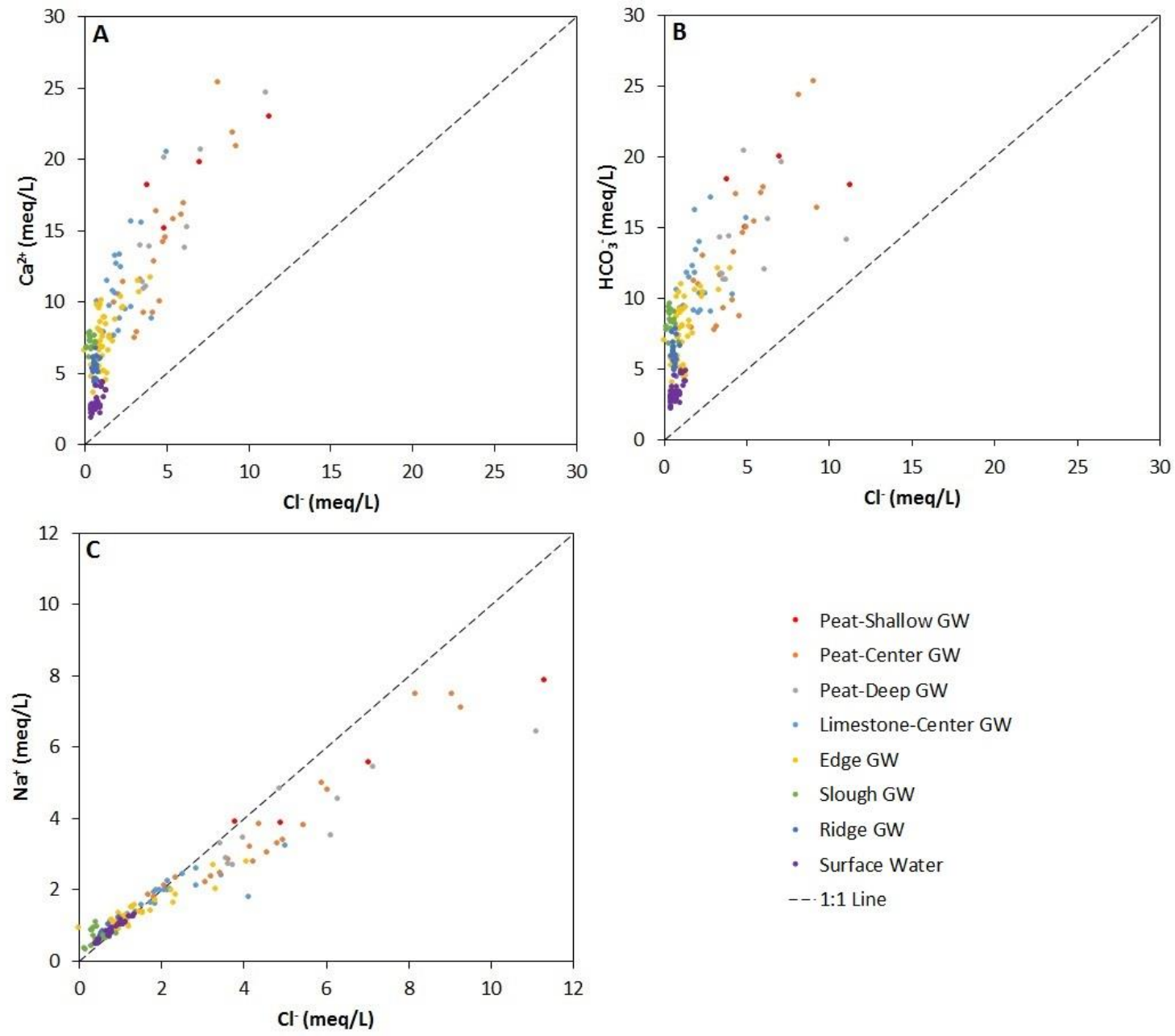

- Peat-Shallow GW

- Peat-Center GW

- Peat-Deep GW

- Limestone-Center GW

- Edge GW

- Slough GW

- Ridge GW

- Surface Water

$--\cdot 1: 1$ Line

Figure 11. Comparisons of A) $\mathrm{Ca}^{2+}$, B) $\mathrm{HCO}_{3}{ }^{-}$, and C) $\mathrm{Na}^{+}$concentrations with $\mathrm{Cl}^{-}$in water samples. 


\section{Mineral saturation states and $\mathrm{pCO}_{2}$}

Saturation indices with respect to calcite varied by season and by sampling location (Figure 12). All the peat-shallow and peat-deep groundwater samples were supersaturated with respect to calcite. In addition, all the peat-center samples from M1W and M3E and all the limestone-center samples from M1E and M4E were supersaturated with respect to calcite (Appendix C). The peat-center groundwater of M2E oscillated between equilibrium and undersaturation with respect to calcite (Appendix C). The saturation indices with respect to calcite in the edge, ridge, and slough groundwater samples oscillated between undersaturation and equilibrium. The surface water was undersaturated with respect to calcite during the wet seasons (Figure 12A) and slightly supersaturated during the dry seasons (Figure 12B).

Saturation indices with respect to aragonite followed the same trend as the calcite saturation indices, but with lower values (Appendix C). In addition, all the peat-deep and peat-shallow groundwater samples were supersaturated with respect to dolomite (Appendix C). Furthermore, all water samples showed a positive and a negative correlation between calcite $\mathrm{SI}$ and $\mathrm{pH}$, and between calcite $\mathrm{SI}$ and $p \mathrm{CO}_{2}$, respectively.

\section{Mass transfer results}

Tables 1 and 2 summarize the final results of the inverse geochemical modeling. Negative values indicate that the phase precipitated and positive values indicate that the phase dissolved. In this case, precipitation refers to a phase that leaves the aqueous solution during groundwater flow, while dissolution refers to a phase that enters the aqueous solution during groundwater flow. 

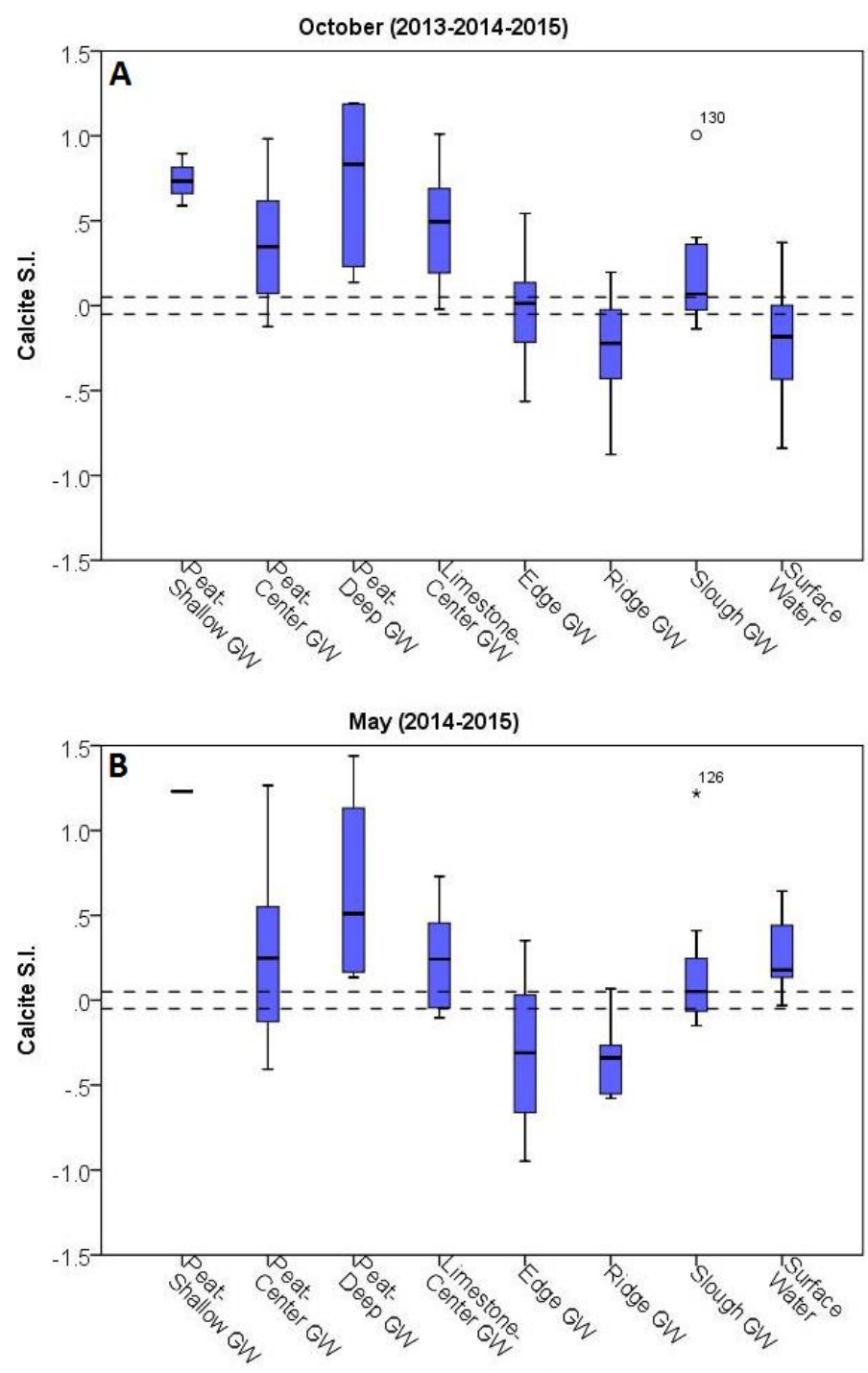

Figure 12. Seasonal and locational variability of saturation indices with respect to calcite. A) October (wet seasons) and B) May (dry seasons). The circle and asterisk marks represent mild and extreme outliers, respectively. The dashed horizontal lines indicate equilibrium with respect to calcite.

The geochemical evolution of groundwater flowing from the edge well (M3E4) and from the peat-deep well (M3E8 Deep) to the peat-center well (M3E5) of island M3E, in both October 2014 and May 2015 (Figures 6C \& 6D), included calcite precipitation and water evaporation (Tables $1 \& 2$ ). Similarly, groundwater flow from the slough well (M3E10S) to M3E5 in May 2015 resulted in calcite precipitation and water evaporation. Additionally, $\mathrm{CO}_{2}$ degassing and $\mathrm{Mg}^{2+}$ adsorption $\left(\mathrm{MgX}_{2}\right.$ precipitation) occurred as 
groundwater flowed from M3E10S, from M3E8 Deep, and from M3E4 to M3E5 in May 2015 (Table 2). In October 2014, geochemical reactions during groundwater flow from the peat-center well (M2E5) to the edge well (M2E4) of M2E, from the edge well (M1E4) to the limestone-center well (M1E5) of M1E, and from the peat-shallow well (M1W5 Shallow) to the peat-center well (M1W5) of M1W, included calcite dissolution and groundwater uptake of $\mathrm{CO}_{2}$ (Table 1).

The resultant mass-balance models also indicated that groundwater flowing from the edge well (M1E4) to the limestone-center well (M1E5) of island M1E, and from the peat-shallow well (M1W5 Shallow) to the peat-center well (M1W5) of M1W, dissolved similar amounts of dolomite and involved $\mathrm{Mg}^{2+}$ adsorption (Table 1). Moreover, processes of $\mathrm{Ca}^{2+} / \mathrm{Na}^{+}$exchange resulted during groundwater flow from the slough well (M3E10S) into the center of M3E (M3E5) of island M3E, and from the M1W5 Shallow to the M1W5 in May 2015, with the latter flow path including $\mathrm{Mg}^{2+}$ adsorption (Table 2). In addition, modeling results indicated the influence of $\mathrm{Ca}^{2+} / \mathrm{Na}^{+}$exchange processes during groundwater flow from the peat-center well (M2E5) to the edge well (M2E4) of island M2E in the October 2014 (Table 1). 
Table 1. Mass transfers along groundwater flow paths in October 2014. Positive values indicate phase dissolution and negative values indicate phase precipitation.

\begin{tabular}{|c|c|c|c|c|c|}
\hline Phases & Flow paths (October 201 & & & & \\
\hline$\left(\mathrm{mol} \mathrm{kg^{-1 }}\right)$ & M1W5 Shallow $\rightarrow$ M1W5 & $\mathrm{M} 1 \mathrm{E} 4 \rightarrow \mathrm{M} 1 \mathrm{E} 5$ & $\mathrm{M} 2 \mathrm{E} 5 \rightarrow \mathrm{M} 2 \mathrm{E} 4$ & $\mathrm{M} 3 \mathrm{E} 4 \rightarrow \mathrm{M} 3 \mathrm{E} 5$ & M3E8 Deep $\rightarrow$ M3E5 \\
\hline Calcite & $2.407 \mathrm{e}-03$ & $2.407 \mathrm{e}-03$ & $1.014 \mathrm{e}-03$ & $-1.752 \mathrm{e}-03$ & $-2.095 \mathrm{e}-03$ \\
\hline $\mathrm{CaX}_{2}$ & & & $1.456 \mathrm{e}-04$ & & \\
\hline $\mathrm{CO}_{2}(\mathrm{~g})$ & $5.208 \mathrm{e}-03$ & $5.208 \mathrm{e}-03$ & $2.317 \mathrm{e}-03$ & & \\
\hline Dolomite & $9.443 \mathrm{e}-04$ & $9.443 \mathrm{e}-04$ & & $3.300 \mathrm{e}-03$ & \\
\hline $\mathrm{H}_{2} \mathrm{O}(\mathrm{g})$ & & & $3.877 \mathrm{e}+01$ & $-4.990 e+01$ & $-2.119 e+01$ \\
\hline $\mathrm{MgX}_{2}$ & $-3.062 \mathrm{e}-04$ & $-3.062 \mathrm{e}-04$ & & $-2.445 e-03$ & \\
\hline $\mathrm{NaX}$ & $6.123 \mathrm{e}-04$ & $6.123 \mathrm{e}-04$ & $-2.913 e-04$ & $4.891 \mathrm{e}-03$ & \\
\hline
\end{tabular}

Table 2. Mass transfers along groundwater flow paths in May 2015. Positive values indicate phase dissolution and negative values indicate phase precipitation.

\begin{tabular}{|c|c|c|c|c|c|}
\hline \multirow{2}{*}{$\begin{array}{l}\text { Phases } \\
\left(\mathrm{mol} \mathrm{kg}^{-1}\right)\end{array}$} & \multicolumn{5}{|l|}{ Flow paths (May 2015) } \\
\hline & M1W5 Shallow $\rightarrow$ M1W5 & $\mathrm{M} 1 \mathrm{E} 4 \rightarrow \mathrm{M} 1 \mathrm{E} 5$ & M3E4 $\rightarrow$ M3E5 & M3E8 Deep $\rightarrow$ M3E5 & $\mathrm{M} 3 \mathrm{E} 10 \mathrm{~S} \rightarrow \mathrm{M} 3 \mathrm{E} 5$ \\
\hline Calcite & $-1.301 \mathrm{e}-03$ & $-6.542 \mathrm{e}-04$ & $-2.756 \mathrm{e}-03$ & $-2.425 \mathrm{e}-03$ & $-4.195 \mathrm{e}-02$ \\
\hline $\mathrm{CaX}_{2}$ & $5.451 \mathrm{e}-04$ & & $3.774 \mathrm{e}-04$ & $1.063 \mathrm{e}-04$ & $6.323 e-03$ \\
\hline $\mathrm{CO}_{2}(\mathrm{~g})$ & $5.142 \mathrm{e}-03$ & $-7.122 \mathrm{e}-03$ & $-1.715 e-02$ & $-2.324 \mathrm{e}-03$ & $-4.525 e-02$ \\
\hline \multicolumn{6}{|l|}{ Dolomite } \\
\hline $\mathrm{H}_{2} \mathrm{O}(\mathrm{g})$ & & $-8.438 e+00$ & $-1.299 e+02$ & & $-5.136 e+02$ \\
\hline $\mathrm{MgX}_{2}$ & & & $-3.774 \mathrm{e}-04$ & $-1.063 e-04$ & $-3.512 \mathrm{e}-03$ \\
\hline $\mathrm{NaX}$ & $-1.090 \mathrm{e}-03$ & & & & $-5.621 e-03$ \\
\hline
\end{tabular}




\section{Soil Mineralogy and Chemistry}

\section{Carbon and mineral content}

Results from the LOI method, shown in Figure 13, indicated that each of the analyzed soil cores contains a different vertical distribution of mineral and carbon concentrations. Peaks of elevated carbon (TC and TIC) concentrations occurred at different depths and varied systematically along with mineral content (shown as mineral residue in Figure 13) in all soil cores. Namely, peaks of elevated TC/TIC concentrations were generally associated with low mineral content, and vice versa. Elevated mineral content was observed in the upper sampling sections down to approximately $40 \mathrm{~cm}$ below the ground surface (Figure 13). In addition, the soils of M1W and M2E showed a continuous increase in mineral content with depth from approximately $70 \mathrm{~cm}$ below the ground surface (Figures 13A, 13B, 13C, \& 13D); whereas the soil of the island M3E showed a continuous decrease in mineral content with depth from the ground surface (Figures 13E \& 13F).

\section{Microscopic observations}

The structure of the soils within the peat-based tree islands and the materials accounting for their TIC concentrations and mineral content, depicted in Figure 13, were characterized using a binocular microscope. In sampling intervals with higher TC/TIC concentrations and lower mineral content (e.g., $50 \mathrm{~cm}-70 \mathrm{~cm}$ below the ground in Figures 13C \& 13D), the peat consisted of a spongy, fine-grained, dark-brown-to-black matrix associated with a framework composed of sawgrass-leaf fragments (Figure 14A) and very fine rootlets, with an occasional presence of fecal pellets. Additionally, in the 
upper $40 \mathrm{~cm}$ below the ground, samples with high mineral content and high TC concentrations (e.g., $0 \mathrm{~cm}$ to $30 \mathrm{~cm}$ below the ground in Figures 13A \& 13B) were associated with the presence of hardwood-vegetation roots.

Quartz grains with a medium-to-fine size range and moderately well sorting were found as the main mineral content in the soil samples. Namely, samples with elevated mineral content had higher amounts of quartz, and vice versa (Figures 14A \& 14B). Similarly, freshwater-gastropod shells made of $\mathrm{CaCO}_{3}$ contributed to the TIC concentrations in the soil samples; i.e., samples with elevated TIC concentrations had higher amounts of gastropod shells (Figures 14A \& 14E). In addition, the inspection of mineral residues after calcination revealed the presence of remnant forms of gastropod shells amongst the quartz grains, supporting the aforementioned observations (Figures $14 \mathrm{C} \& 14 \mathrm{D})$. Small amounts of iron oxide were also observed in some of the mineral residues obtained after calcination. Moreover, aggregates of quartz grains cemented with $\mathrm{CaCO}_{3}$ were found randomly distributed in the original samples (non-calcinated) corresponding to the upper $24 \mathrm{~cm}$ below the ground surface, in islands M1W and M3E (Figures 14B \& 14F). The calcareous nature of the cement was confirmed by the effervescence of the aggregates after addition of $\mathrm{HCl}$.

The depositional fabric of the $\mathrm{CaCO}_{3}$ cementing the quartz aggregates, shown in Figures 13B and 13F, was characterized with a petrographic microscope in crosspolarized light. The cement was identified as isopachous micrite (Figures 15A, 15B, \& 15C) uniformly distributed around the quartz grains, on some of which organic-matter coatings were observed (Figure 15C). Moreover, freshwater-sponge spicules with and without dissolution pits were observed in most soil samples (Figures 15D \& 15E). 

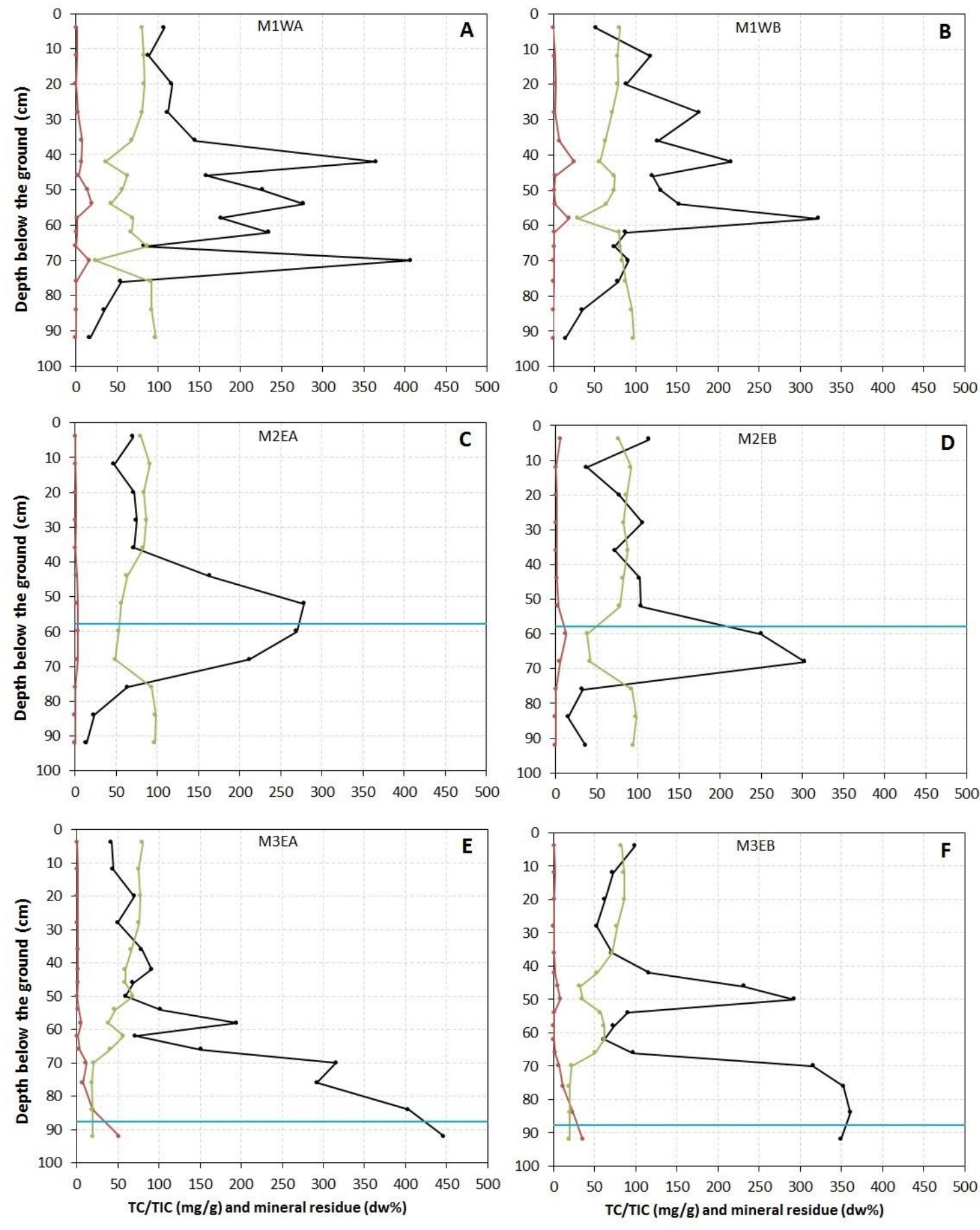

-TC - TIC - Mineral Residue —Water Table

Figure 13. Vertical profiles showing concentrations of total carbon (TC), total inorganic carbon (TIC), and mineral residue in the soils of three peat-based tree islands. A) M1WA and B) M1WB are two soil cores collected from the M1W tree island. C) M2EA and D) M2EB are two soil cores collected from the M2E tree island. E) M3EA and F) M3EB are two soil cores collected from the M3E tree island. Concentrations of TC/TIC are expressed in $\mathrm{mg} / \mathrm{g}$ and mineral residue is expressed in percent of dry weight (dw\%) soil. The blue horizontal lines represent the water table below the center of the islands in May 2015, when the samples were collected (refer to Figures 7B \& 7D). 


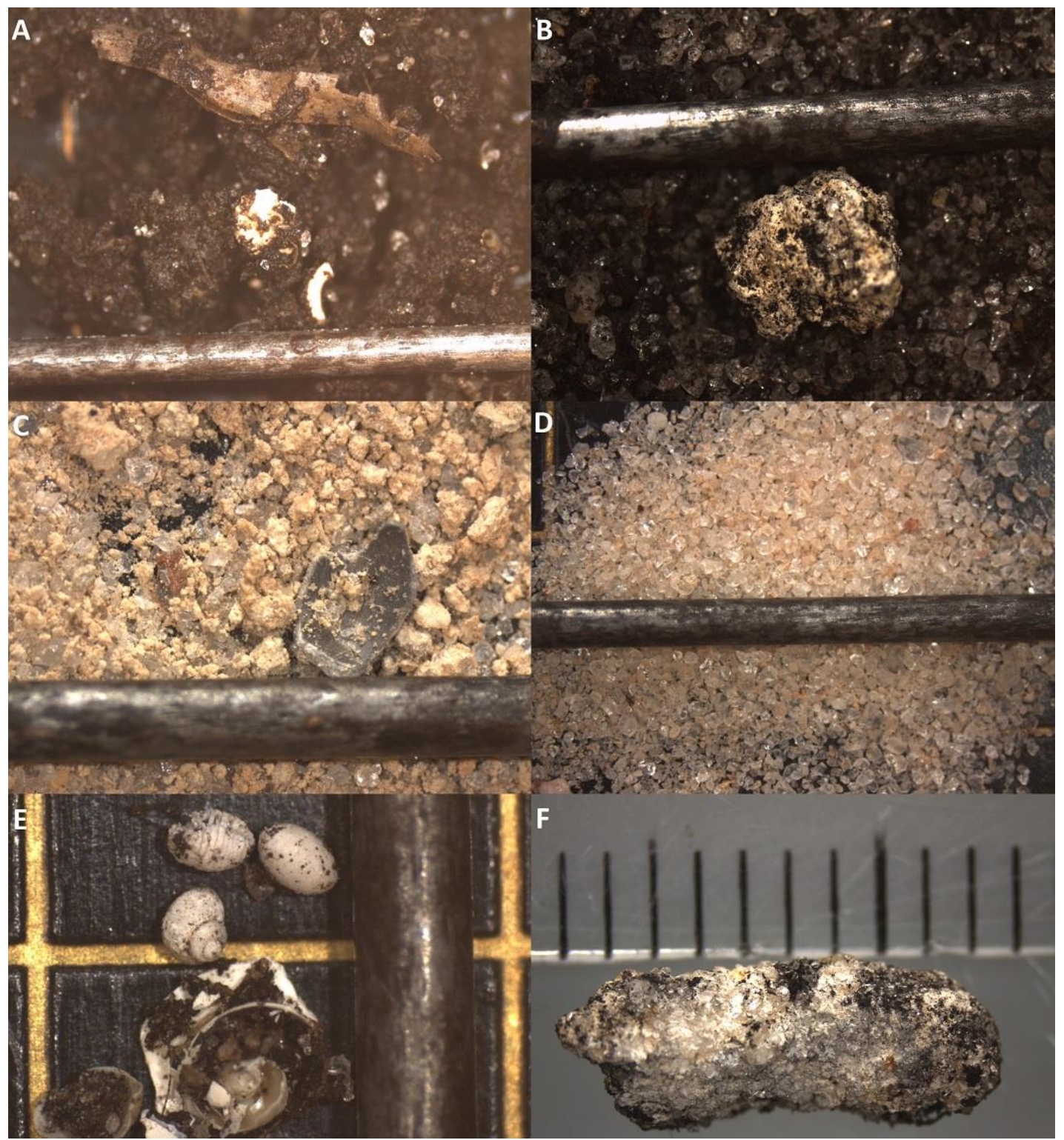

Figure 14. Photomicrographs of soil samples taken through a binocular microscope. A) Loxahatchee peat with low amounts of quartz containing gastropod shells. B) Loxahatchee peat with high amounts of quartz containing a few aggregates of quartz grains cemented with $\mathrm{CaCO}_{3}$. C) Mineral residue with high TIC concentrations showing remnant forms of gastropod shells. D) Mineral residue with low TIC concentrations mainly consisting of quartz. E) Freshwater-gastropod shells. E) Aggregate of quartz grains cemented with $\mathrm{CaCO}_{3}$ (the black lines are $1 \mathrm{~mm}$ apart). The metal bar used for scale in photomicrographs A through $\mathrm{E}$ is $1 \mathrm{~mm}$ wide. 


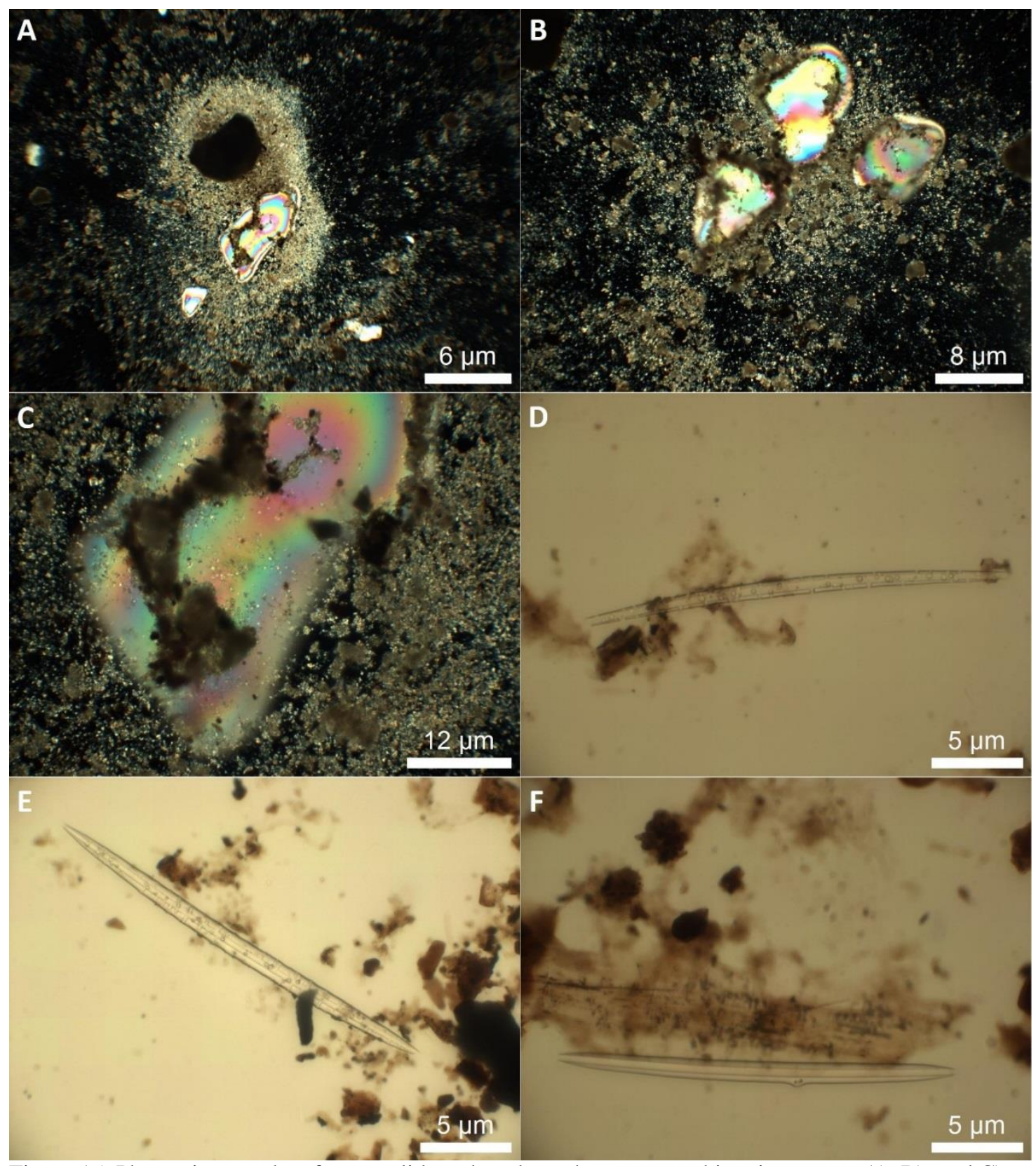

Figure 15. Photomicrographs of smear slides taken through a petrographic microscope. A), B), and C) Quartz grains embedded in isopachous-micritic cement with organic-matter coatings (cross polarized light). D) and F) Freshwater-sponge spicules with dissolution pits (plane polarized light). E) Freshwater-sponge spicule without dissolution pits (plane polarized light). 


\section{DISCUSSION}

Driving Mechanisms of Seasonal Hydrologic Processes

\section{Influence of evapotranspiration on groundwater flow and solute transport}

In general, evapotranspiration was the main driving mechanism of groundwater flow and solute transport towards the center of the tree islands at LILA, but the lithological compositions of the islands played a key role in solute retention. The extent to which evapotranspiration processes influenced groundwater and solute dynamics across the macrocosms, was indicated by the seasonal variability of the conservative hydrochemical tracers $\mathrm{Cl}^{-}$and $\delta^{18} \mathrm{O}$ (Bibby, 1981; Kendall \& Caldwell, 1998). Namely, low isotopic enrichment in the groundwater below the islands indicated a predominant rainfall influence, while higher isotopic enrichment was indicative of surface watergroundwater interactions in the tree islands (Sullivan et al., 2016). Likewise, seasonal changes in the surface water chemistry indicated the effects of evaporation on solute concentrations, whereas the seasonal hydrochemical variability in the peat-shallow, peatcenter, peat-deep, and limestone-center groundwaters indicated a dominant transpiration effect (Figure 16).

The seasonal variability of $\delta^{18} \mathrm{O}$ composition and the seasonal stability of $\mathrm{Cl}^{-}$ concentrations in the edge groundwater (Figure16), indicated that the edges of the islands acted as transition zones for groundwater exchange between the sloughs and the tree islands. In the limestone-core islands, surface water flowed into the center of the islands with relatively more ease in comparison to the peat-based islands, as indicated by the higher $\delta^{18} \mathrm{O}$ values and lower $\mathrm{Cl}^{-}$concentrations in the limestone-center groundwater

compared to the peat-center groundwater (Figure 16). Moreover, lower $\delta^{18} \mathrm{O}$ enrichment 
in the peat-center groundwater, suggested a predominant rainfall source, while the higher $\mathrm{Cl}^{-}$concentrations were indicative of longer residence times allowing groundwater to be more influenced by transpiration processes.
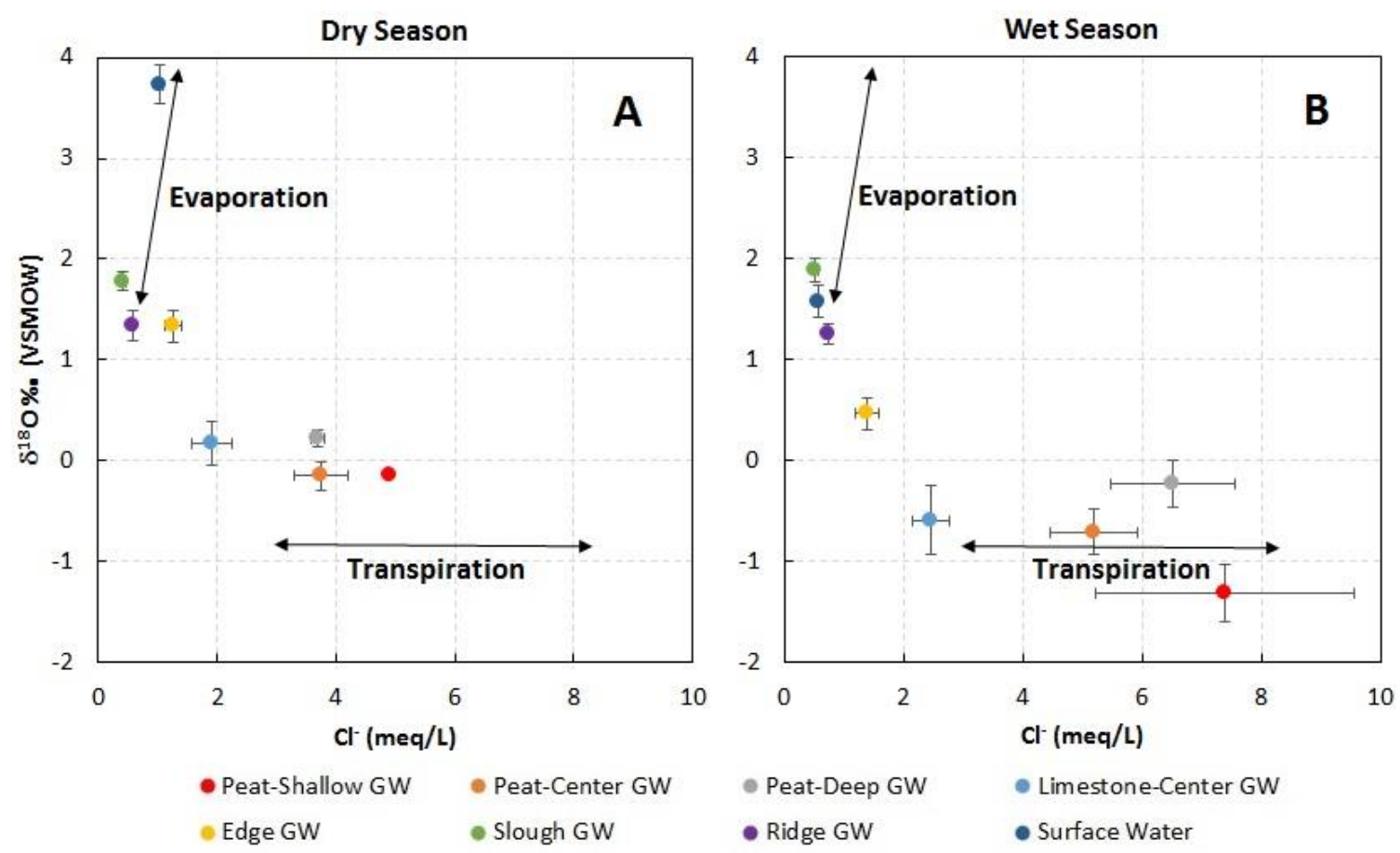

Figure 16. Seasonally-averaged $\mathrm{Cl}^{-}$concentrations and $\delta^{18} \mathrm{O}$ enrichment of water samples collected at different sites during the study period in: A) May (Dry Season) and B) October (Wet Season). Error bars represent standard errors.

The tendency of the peat-deep groundwater to have higher $\mathrm{Cl}^{-}$concentrations than the center groundwaters (Figure 9B), indicated that solutes were concentrated into the deeper groundwater beneath the islands. Similar mechanisms of downward solute accumulation into deep aquifer layers have been documented in other sub-tropical wetlands, where the elevated evapotranspiration rates of tree islands maintain freshwater quality by redistributing saline groundwater into underlying sandy and clayey sediments (Bauer-Gottwein et al., 2007; Ramberg \& Wolski, 2008; Humphries et al., 2010; 2011). 
Furthermore, the hydrochemical behavior of the peat-shallow groundwater, with greater seasonal variability in $\mathrm{Cl}^{-}$concentrations and isotopic composition, suggested the importance of precipitation in regulating the shallow groundwater chemistry in the peatbased tree islands.

\section{Influence of lithology on groundwater flow and solute transport}

Seasonal groundwater and hydrochemical dynamics in the peat-based tree islands were also regulated by vertical ratios of peat-to-sand within their shallow soils (Figure 13). Mixtures of peat with sand in different proportions along the soil profiles may have affected their hydraulic properties, including hydraulic conductivity, water storage, and specific yield, thereby affecting solute transport and gas fluxes (Rezanezhad et al., 2016). In general, the elevated sand content within the shallow soil of the peat-based tree islands (Figure 13) may have artificially increased the connectivity of the pore spaces, facilitating horizontal groundwater flow paths and advective chemical transport across the islands. The groundwater dynamics across M2E reflected this hydraulic phenomenon, with a homogeneous seasonal fluctuation of the water table across the entire macrocosm (Figures 7A \& 7B), indicating enhanced lateral connectivity with the adjacent sloughs and horizontal groundwater movement across the island. Similarly, predominantly horizontal groundwater flow paths across $\mathrm{M} 1 \mathrm{~W}$ may have been responsible for the increasing isotopic enrichment, and the continuously decreasing $\mathrm{Cl}^{-}$concentrations in the groundwater below the center of the island (M1W5) throughout the study period. Chemical concentrations in M1W5 (Appendix A) tended to approach those in the edge groundwater (M1W8), indicating surface water seepage into the island. Furthermore, the 
persistent water table depression across M3E (Figures 7C \& 7D) may have been sustained by the decreasing sand content towards the bottom of its shallow soil profile (Figures 13E \& 13F). The decomposing Loxahatchee peat observed at the bottom of the soil of M3E (Figure 13A) and the clayey sediments underlying the island reported by Sullivan et al. (2011), may have reduced the soil pore spaces and specific yield (Boelter, $1968 ; 1969)$, thereby assisting seasonal evapotranspiration processes in continuously depressing the water table and concentrating solutes.

Lower chemical concentrations and elevated isotopic enrichment in the groundwater below the limestone-core tree islands (Figure 9), indicated that limestone substrates facilitated shorter groundwater residence times, and surface water-groundwater interactions. In turn, those hydrological interactions maintained the relatively stable hydrochemical conditions in the limestone islands, particularly during decreasing surfacewater stages (Figure 6), as suggested by the steady increase of $\mathrm{Cl}^{-}$concentrations in the limestone-center groundwater throughout the study period (Figure 9B). Such increase in $\mathrm{Cl}^{-}$concentrations, despite seasonality, demonstrates that the long-term adaptation of developing tree islands is fundamentally related to the hydraulic properties of their minerals substrates. For example, increasing specific yield with increasing depth of the water table in the soils of the peat-based tree islands was documented by Sullivan et al. (2011), and was attributed to the sand layer underlying such islands. Therefore, the observed long-term increase of $\mathrm{Cl}^{-}$concentrations in the limestone-center groundwater (Figure 9B), may be indicative of a higher ability the limestone-core tree islands to sustain a water-table depression (Figures 8B \& 8D) and concentrate solutes during low surface-water stages, compared to the peat-based tree islands containing elevated sand 
proportions in their shallow soils. Furthermore, during high surface-water stages, limestone cores and sandy peat soils were less effective in concentrating solutes below the tree islands, in comparison to a peat soil with lower sand proportions.

\section{Water-Rock Interactions and Calcite Solubility}

\section{Cation exchange processes}

Because $\mathrm{Cl}^{-}$is a conservative ion, i.e., it tends to not be affected by adsorption and reaction processes (Bibby, 1981), the excess concentrations of $\mathrm{Ca}^{2+}$ and $\mathrm{HCO}_{3}{ }^{-}$with respect to $\mathrm{Cl}^{-}$concentrations (Figures $11 \mathrm{~A} \& 11 \mathrm{~B}$ ) in all water samples indicated a tendency for calcite dissolution within the LILA groundwater system. However, the dissolution of carbonate minerals may not have been the only source of dissolved $\mathrm{Ca}^{2+}$ and $\mathrm{Mg}^{2+}$ concentrations in the groundwater at LILA. Because the precipitation of sodium minerals is unlikely in this freshwater environment (Reading, 2009), and $\mathrm{Na}^{+}$ uptake by trees is insignificant (Landmeyer, 2012), cation exchange processes were inferred by examining the ratios of $\mathrm{Na}^{+}$to $\mathrm{Cl}^{-}$concentrations in the groundwater. The observed depletion of $\mathrm{Na}^{+}$with respect to $\mathrm{Cl}^{-}$concentrations in the shallow-peat, peatcenter, peat-deep, and limestone-center groundwater samples (Figure 11C), suggested that $\mathrm{Ca}^{2+} / \mathrm{Na}^{+}$exchange potentially contributed to the increase in $\mathrm{Ca}^{2+}$ concentrations observed in the groundwater beneath the tree islands. Likewise, cation exchange processes were more likely to occur during the dry seasons, as inferred by examining $\mathrm{Na}^{+}: \mathrm{Cl}^{-}$ratios.

Inverse geochemical modeling results effectively indicated that $\mathrm{Ca}^{2+} / \mathrm{Na}^{+}$ exchange was an important process in the geochemical evolution of groundwater flowing 
beneath the slough into the center of island M3E, and from the shallow soil downward into the center of $\mathrm{M} 1 \mathrm{~W}$ during the dry season (Table 2). In addition, modeling results indicated the influence of $\mathrm{Ca}^{2+} / \mathrm{Na}^{+}$exchange during lateral groundwater flow from the center of M2E towards the edge of the island in the wet season (Table 2). Therefore, cation exchange processes exerted a greater influence on the geochemistry of groundwater beneath the peat-based tree islands.

The peat fraction of the tree-island soils may have been partially responsible for $\mathrm{Ca}^{2+} / \mathrm{Na}^{+}$exchange, as organic soils are characterized by a humus layer, which includes an associated negative charge (Reddy \& DeLaune, 2008). Thus, the greater the organic matter content, the higher the cation exchange capacity (CEC) of the soils (Reddy \& DeLaune, 2008). Moreover, Sullivan et al. (2011) reported the presence of clayey sediments within the soils of macrocosm M3 at LILA. Also, in the northern Everglades, Sawyer \& Wieland (1988) documented the distribution of kaolinite, chlorite, and mixedlayer smectite along the flanks and at the southern boundary of the Loxahatchee basin, where smectite is the dominant clay mineral. Therefore, the CEC of such clays, particularly of smectites, which have a higher surface charge and a CEC independent of solution chemistry (Langmuir, 1997), could have contributed to $\mathrm{Ca}^{2+} / \mathrm{Na}^{+}$exchange in the soils at LILA.

\section{Carbonate minerals}

Elevated $\mathrm{Ca}^{2+}$ and $\mathrm{Mg}^{2+}$ concentrations supported the observed supersaturation with respect to aragonite, calcite (Figures $12 \mathrm{~A} \& 12 \mathrm{~B}$ ), and dolomite in the groundwater beneath most tree islands, particularly in the peat-shallow and peat-deep groundwater. Whether mineral dissolution or precipitation actually occurred could not be inferred 
solely by saturation index computations, as the saturation tendency of a water sample at a given instant does not capture the effects of kinetic reactions in relation to variable rates of water flow on water chemistry (Nordstrom \& Campbell, 2014). Moreover, inverse mass-balance models were helpful in assessing water-rock interactions processes along groundwater flow paths.

In the northern Everglades, dolomite and the calcium oxalate mineral, weddellite, are present as accessory minerals in sediments underlying peat deposits, such as clays and sand-sized quartzose sediments, with weddellite originating from biogenic precipitation within peat-forming plant materials (Sawyer \& Wieland, 1988; Harris, 2011). For these reasons, dolomite was included as a mineral phase in the inverse geochemical modeling. However, only models that resulted in dolomite dissolution as a potential $\mathrm{Mg}^{2+}$ source, or models that did not precipitate dolomite and complied with other model constraints, were selected as final results because of kinetic infeasibility for dolomite precipitation in this groundwater system (Arvidson \& Mackenzie, 1996; 1999). Additionally, most of the resultant models involving dolomite as a mineral phase, particularly those in the wet season when dolomite dissolution occurred (Table 1), also resulted in $\mathrm{MgX}_{2}$ precipitation, i.e., $\mathrm{Mg}^{2+}$ adsorption, which could also be attributed to $\mathrm{Mg}^{2+}$ uptake by plants (Landmeyer, 2012).

Hydrogeochemical modeling indicated M3E as the only tree island where a longterm accumulation of calcite was thermodynamically likely to occur under current climatic and hydrologic conditions (Tables $1 \& 2$ ). The continuous groundwater flow into the island (Figure 7C \& 7D) transporting and concentrating solutes, coupled with groundwater evaporation (Tables $1 \& 2$ ) and $\mathrm{CO}_{2}$ degassing to the atmosphere, 
particularly during the dry season (Table 2), were most likely responsible for the supersaturated conditions with respect to calcite in M3E. Mass transfer results indicated that water evaporation in October 2014 was also an important factor regulating the geochemical evolution of groundwater flowing from the edge and from the deeper soil into the center of the island (Table 1), because the resultant models that did not include water evaporation involved dolomite precipitation. In turn, these simulated processes were facilitated by the higher permeability of the upper portion of the soil, associated to an elevated sand content, and were in agreement with speciation calculations (Appendix C).

The contribution of the elevated sand content in the peat soils to the upward diffusion of $\mathrm{CO}_{2}$, supporting groundwater supersaturation with respect to $\mathrm{CaCO}_{3}$ (Figure 12), was also evidenced in other tree islands at LILA. In M1W, diffusion of $\mathrm{CO}_{2}$ to the atmosphere was suggested by $p \mathrm{CO}_{2}$ values, which were prevalently highest, intermediate, and lowest, in the peat-deep (M1W8 Deep), peat-center (M1W5), and peat shallow (M1W5 Shallow), respectively (Appendix C), despite the predominantly horizontal groundwater flow paths and surface water seepage into the island indicated by hydrochemical tracers. Similarly, the center groundwater (M2E5) of M2E maintained higher $p \mathrm{CO}_{2}$ values throughout the study period, compared to the edge groundwater (M2E4). The inverse simulation of these processes indicated that horizontal groundwater flow paths (Figure 7A) and surface water-groundwater interactions superseded the effects on mineral saturation by $\mathrm{CO}_{2}$ diffusion to the atmosphere, preventing the long-term accumulation of calcite within the tree islands. Specifically, seasonal cycles of calcite precipitation and dissolution in the peat-based island $\mathrm{M} 1 \mathrm{~W}$ and the limestone-core island 
M1E (Tables 1 and 2), two of the oldest islands at LILA, would not support a long-term accumulation of calcite. This was further suggested by lower quantities of potential calcite precipitation during the dry season (Table 2), compared to slightly higher quantities of potential calcite dissolution during the wet season (Table 1). In the case of the limestone-core island M1E, dry-season models with lower residual errors that did not result in calcite precipitation were also found (results not shown). In the case of the peatbased island M2E, the groundwater flow path outward from the center of the island (Figure 7A), resulted in calcite dissolution, and no models including calcite precipitation were found. These results were in agreement with the observed undersaturation with respect to calcite in the peat-center groundwater at M2E (Appendix C).

\section{Shallow Soil Composition}

The examination of the first meter of soil from the ground surface in three peatbased tree islands indicated that calcite has not accumulated in the capillary fringe above the water table, with both the carbon analyses and microscopic observations supporting this conclusion. The heterogeneous occurrence of carbon peaks at different depths along the soil profiles was associated to a decrease in the mineral content of the soil samples (Figure 13). Also, microscopic observations revealed that fine-sized quartz grains accounted for the mineral content of the soils (Figures 14A, 14B, 14C, \& 14D). Thus, intervals with peaks of elevated TC/TIC concentrations and lower mineral content, corresponded to layers of peat with lower quartz content. Freshwater-gastropod shells (Figures 14A, 14C, \& 14E), which are characteristic in calcific muds and peat deposits in the northern Everglades (Gleason et al., 1974; Sawyer \& Wieland, 1988), were the main 
factor accounting for the TIC concentrations measured in the soil samples. Additionally, the random presence of aggregates of quartz grains cemented with calcium carbonate (Figures 14B, 14F, 15A, 15B, \& 15C) within the first $24 \mathrm{~cm}$ of the soil of islands M1W and M3E were contributing to smaller fractions of the TIC concentrations. The identification of the calcium carbonate cementing the quartz grains as uniformlydistributed isopachous micrite (Figures 15A, 15B, \& 15C), indicated a typical cementation process in phreatic zones during meteoric diagenesis, reflecting a complete saturation of pores with water in that environment (Scholle \& Ulmer-Scholle, 2003). These results suggested that the cemented quartz aggregates corresponded to debris derived from the construction process of LILA, which involved sculpting the topography from existing impoundments (Sklar et al., 2004). The construction process may also explain the higher sand content observed in the upper sections of the tree-island soils. The sand content in the peat at LILA came from an underlying sediment layer consisting of quartzose sand, shell fragments, and clay (Sullivan el at., 2011). A sedimentary unit with such characteristics, namely the Pamlico formation, borders the northern Everglades and underlies peat deposits, including tree islands in the Loxahatchee basin (Gleason et al., 1974; Sawyer \& Wieland, 1988). Analyzing the sediments underlying the tree islands at LILA becomes necessary to better characterize the geology of the deeper portion of the aquifer, providing better constraints for simulating the geochemical evolution of groundwater along hydrologic flow paths. 


\section{Implications on Biogeochemical Processes and Limitations}

In order to simulate the geochemical evolution of the groundwater in LILA, the simplest set of reactions that could explain the data under specified uncertainty limits were considered. However, the effects of complex biogeochemical reactions that are likely to occur in organic soils, such as methanogenesis $\left(\mathrm{CH}_{4}\right.$ production) and decomposition of organic matter, involving microbial oxidation processes, were not included. For example, methanogenesis and $\mathrm{CO}_{2}$ reduction mediated by microorganisms could promote the formation of authigenic micritic calcite under reducing conditions (Feng \& Chen, 2015). Likewise, Schonhoff (2015) indicated that in soils where water levels remained higher for longer periods of time, more reduced conditions resulted in greater $\mathrm{CH}_{4}$ production within the peat-based macrocosms M1W and M4W at LILA. Although such areas corresponded to the deep sloughs, comparative measurements of gaseous emissions indicated that $\mathrm{CH}_{4}$ and $\mathrm{CO}_{2}$ effluxes where higher within the first 40 $\mathrm{cm}$ below the ground surface in the center of the peat-based islands M1W and M4W, relative to the gaseous effluxes from the soils at edges of those islands (Schonhoff, 2015). Furthermore, aerobic decomposition of the Loxahatchee peat, i.e., the mixed sawgrasswater lily peat utilized for the construction of LILA (Gleason et al., 1974; Sklar et al., 2004), could inhibit calcite precipitation through the introduction of humic substances (Hoch et al., 2000). Such organic compounds could block potential sites for crystal nucleation (Amrhein \& Suarez, 1987; Hoch et al., 2000; Meyer et al., 2013), enhancing calcite solubility and resulting in the supersaturation with respect to $\mathrm{CaCO}_{3}$ observed in the groundwater beneath some of the tree islands. Thus, future modeling of the mineral 
saturation states and chemical reactions in the LILA groundwater system should include measurements of dissolved organic compounds.

Moreover, the breakdown of organic matter under flooded and anoxic conditions can promote soil phosphorus release from restoration wetland soils (Aldous et al., 2005). In the Everglades tree islands, the decomposition of leaf litter results in higher soil phosphorus concentrations (Troxler Gann \& Childers, 2006; Rodriguez et al., 2014). Therefore, the significant and positive correlations between TOC and TP concentrations, as well as between $\mathrm{Cl}^{-}$and TOC concentrations observed in the peat-center groundwater samples, may have resulted from the breakdown of organic matter. This hypothesis was also supported by higher TOC and TP concentrations during the wet seasons. Conversely, saturations indices with respect to calcite were not correlated with TP, nor with $\mathrm{PO}_{4}{ }^{3-}$ concentrations in the groundwater beneath the tree islands, suggesting that phosphorus dynamics was unrelated to the $\mathrm{CaCO}_{3}$ geochemistry at LILA. 


\section{CONCLUSIONS}

Characterizing and quantifying the lithological properties of the seasonally unsaturated zone in three peat-based tree islands at LILA, helped to elucidate the causes for distinct groundwater flow patterns and in turn, the water-rock interactions processes in those islands. The effects of seasonal evapotranspiration processes on the seasonal dynamics of the water table and groundwater geochemistry across the tree islands were highly influenced by the lithological composition of the soils, inherent to the construction process of LILA. Peat-based tree islands with elevated sand content showed greater lateral connectivity with their adjacent sloughs, facilitating surface water seepage and horizontal groundwater flow paths. Similarly, limestone-core tree islands favored surface water-groundwater interactions, particularly during high surface water stages. However, limestone cores were more effective in supporting evapotranspiration rates to lower the water table during low surface water stages, increasing solute concentrations in the groundwater beneath the tree islands. Furthermore, the Loxahatchee peat with low sand content at the bottom of the soil in M3E, supported seasonal evapotranspiration processes in continuously depressing the water table beneath the island, concentrating greater amounts of reactive solutes compared to the rest of the islands. Additionally, the higher sand content in the upper portion of the soil in M3E allowed for an effective gaseous exchange with the atmosphere, including $\mathrm{CO}_{2}$ degassing and water evaporation, particularly during the dry season.

Elevated $\mathrm{Ca}^{2+}$ and $\mathrm{Mg}^{2+}$ concentrations in the groundwater beneath some tree islands supported the supersaturation with respect to calcite, and in some cases, with respect to dolomite. However, excess concentrations of $\mathrm{Ca}^{2+}$ and $\mathrm{HCO}_{3}{ }^{-}$with respect to 
$\mathrm{Cl}^{-}$concentrations in all the water samples revealed an overall tendency for the dissolution of carbonate minerals within the LILA groundwater system. A fraction of the $\mathrm{Ca}^{2+}$ concentrations in the groundwater beneath the tree islands was attributed to $\mathrm{Ca}^{2+} / \mathrm{Na}^{+}$exchange processes. Additionally, geochemical inverse modeling of the groundwater evolution along hydrologic flow paths within the tree islands, in two different seasons, indicated that calcite would not accumulate under current climatic and hydrologic conditions within the soils of the investigated islands, except in M3E. The vertical peat-to-sand ratio in the soil of $\mathrm{M} 3 \mathrm{E}$, with a decreasing mineral fraction down to $1 \mathrm{~m}$ deep from the ground surface, facilitated the adequate thermodynamic conditions for calcite precipitation from groundwater. Namely, degassing of $\mathrm{CO}_{2}$ and water loss through evapotranspiration in the unsaturated zone, coupled with constant inputs of dissolved ions from the adjacent slough groundwater, may promote a long-term accumulation of calcite within the deeper aquifer sediments underlying the island, as suggested by mass-balance models.

In the peat-based tree islands, analyses of groundwater chemistry indicated that phosphorus concentrations were not regulated by $\mathrm{CaCO}_{3}$ geochemistry, but by the breakdown of organic matter releasing phosphorus from the soil, particularly during the wet seasons. Future hydrogeochemical studies should then consider biogeochemical reactions that can affect $\mathrm{CaCO}_{3}$ geochemistry within the soils of the tree islands at LILA. Additionally, future work should focus on analyzing the deeper sediments underlying the tree islands at LILA, in order to better constrain all the mineral phases that could potentially react and affect $\mathrm{CaCO}_{3}$ solubility along groundwater flow paths. The sedimentological characterization of the shallow substrate in the peat-based tree islands 
indicated that calcite has not accumulated within the seasonally unsaturated zone in response to evapotranspiration. Characterizing the sediments beneath the sawgrass ridges would then complement the soil characterization conducted in this investigation, as they are the only topographic features that were not altered by the construction process of LILA. Finally, a more detailed knowledge of the aquifer geology, coupled with the implementation of biogeochemical processes that occur within the soils of the tree islands, would provide more accurate constraints for hydrogeochemical modeling efforts that serve as a predictive tool for the future stability of constructed Everglades tree islands, under managed hydrologic conditions. 


\section{REFERENCES}

Aich, S., Dreschel, T., Cline, E., \& Sklar, F. (2011). The Development of a Geographic Information System (GIS) to Document Research in an Everglades Physical Model. Journal of Environmental Science and Engineering, 5, 289-302.

Aldous, A., McCormick, P., Ferguson, C., Graham, S., \& Craft Chris. (2005). Hydrologic Regime Controls Soil Phosphorus Fluxes in Restoration and Undisturbed Wetlands. Restoration Ecology, 13(2), 341-347.

Ali, A., Abtew, W., Van Horn , S., \& Khanal, N. (2000). Temporal and spatial characterization of rainfall over Central and South Florida 1. Journal of the American Water Resources Association, 36(4), 833-848.

Almendinger, J., \& Leete, J. (1998). Peat characteristics and groundwater geochemistry of calcareous fens in the minnesota river basin, USA. Biogeochemistry, 43(1), 17-41.

Alonso-Zarza, A., \& Wright, V. (2010). Calcretes. In A. Alonso-Zarza, \& L. Tanner, Developments in Sedimentology (Vol. 61, pp. 225-267).

Amrhein, C., \& Suarez, D. (1987). Calcite supersaturation in soils as a result of organic matter mineralization. Soil Science Society of America Journa, 51(4), 932-937.

Armenteros, I. (2010). Diagenesis of Carbonates in Continental Settings. In A. AlonsoZarza, \& L. Tanner, Developments in Sedimentology (Vol. 62, pp. 61-151).

Arvidson, R. S., \& Mackenzie, F. T. (1996). Tentative kinetic model for dolomite precipitation rate and its application to dolomite distribution. Aquatic Geochemistry, 2(3), 273-298.

Arvidson, R., \& Mackenzie, F. (1999). The dolomite problem; control of precipitation kinetics by temperature and saturation state. American Journal of Science, 299(4), 257288.

Bauer-Gottwein, P., Langer, T., Prommer, H., Wolski, P., \& Kinzelbach, W. (2007). Okavango Delta Islands: Interaction between density-driven flow and geochemical reactions under evapo-concentration. Journal of Hydrology, 335(3), 389-405.

Bibby , R. (1981). Mass transport of solutes in dual-porosity media. Water Resources Research, 17(4), 1075-1081.

Boelter, D. (1968). Important physical properties of peat materials. Proceedings of the, $150-154$. 
Boelter, D. (1969). Physical Properties of Peats as Related to Degree of Decomposition. Soil Science Society of America Journal, 33(4), 606-609.

Coultas, C. L., Schwadron, M., \& Galbraith, J. M. (2008). Petrocalcic Horizon Formation and Prehistoric People's Effect on Everglades Tree Island Soils, Florida. Soil Horizons, 49(1), 16-21.

Craighead, F. (1974). Hammocks of South Florida. In P. J. Gleason, Environments of South Florida: Present and Past (pp. 53-60). Naples: Miami Geological Society.

Davis, S. M., Gunderson, L. H., Park, W. A., Richardson, J. R., \& Mattson, J. E. (1994). Landscape Dimension, Composition, and Function in a Changing Everglades Ecosystem. In S. M. Davis, \& J. C. Ogden, Everglades: The Ecosystem and its Restoration (pp. 419444). Boca Raton: St. Lucie Press.

Dreschel, T., Cline, E., \& Sklar, F. (2010). Fine Tuning the Everglades Restoration: The LILA Facility. Poster, South Florida Water Management District, West Palm Beach.

Retrieved April 2016, from http://mytest.sfwmd.gov/portal/page/portal/pg_grp_sfwmd_watershed/lila__loxahatchee_i398/tab744033/lila\%20poster\%202010.pdf

FCE LTER. (2000). FCE I Proposal - 2000-2006. Florida International University. FIU Digital Commons. Retrieved from http://digitalcommons.fiu.edu/fce_lter_proposals_reports/9

Feng, J., \& Chen, D. (2015). Characterization of authigenic carbonates from Huoshaogang landfill, Guangzhou, China: implication for microbial metabolism. Environmental Earth Sciences, 74(6), 4839-4851.

Gleason, P. J., Cohen, A. D., Smith, W. G., Brooks, K. H., Stone, P. A., Goodrick, R. L., \& Spackman Jr., W. (1974). The environmental significance of Holocene sediments from the Everglades and saline tidal plain. In P. J. Gleason, Environments of South Florida: Present and Past (pp. 287-341). West Palm Beach: Miami Geological Society.

Gleason, P., \& Stone, P. (1994). Age, Origin, and Landscape Evolution of the Everglades Peatland. In J. C. Ogden, \& S. M. Davis, Everglades: the ecosystem and its restoration (pp. 149-198). Boca Raton, Florida, USA: St. Lucie Press.

Graf, M., Schwadron, M., Stone, P., Ross, M., \& Chmura, G. (2008). An Enigmatic Carbonate Layer in Everglades Tree Island Peats. Eos, Transactions American Geophysical Union, 89(12), 117-118.

Harris, W. (2011). Mineral distribution and weathering in the greater Everglades: Implications for restoration. Critical reviews in environmental science and technology, 41(S1), 4-27. 
Hoch, A., Reddy, M., \& Aiken, G. (2000). Calcite crystal growth inhibition by humic substances with emphasis on hydrophobic acids from the Florida Everglades. Geochimica et Cosmochimica Acta, 64(1), 61-72.

Humphries, M., Kindness, A., Ellery, W., \& Hughes, J. (2010). Sediment geochemistry, mineral precipitation and clay neformation on the Mkuze River floodplain, South Africa. Geoderma, 157(1), 15-26.

Humphries, M., Kindness, A., Ellery, W., \& Hughes, J. (2011). Water chemistry and effect of evapotranspiration on chemical sedimentation on the Mkuze River floodplain, South Africa. Journal of Arid Environments, 75, 555-565.

Kendall, C., \& Caldwell, E. A. (1998). Fundamentals of isotope geochemistry. In C. Kendall, \& J. J. McDonnell, Isotope Tracers in Catchment Hydrology (pp. 51-86). Amsterdam: Elsevier.

Landmeyer, J. E. (2012). Fundamentals of Plant Anatomy and Physiology Related to Water Use. In J. E. Landmeyer, Introduction to Phytoremediation of Contaminated Groundwater. Historical Foundation, Hydrologic Control, and Contaminant Remediation (pp. 43-93). Springer Netherlands.

Langmuir, D. (1997). Aqueous Environmental Geochemistry. Upper Saddle River: Prentice Hall.

Larsen, L. G., \& Harvey, J. W. (2010). How Vegetation and Sediment Transport Feedbacks Drive Landscape Change in the Everglades and Wetlands Worldwide. The American Naturalist, 173(3), E66-E79.

Larsen, L., Aumen, N., Bernhardt, C., Engel, V., Givnish, T., Hagerthey, S., . . Willard, D. (2011). Recent and historic drivers of landscape change in the Everglades ridge, slough, and tree island mosaic. Critical Reviews in Environmental Science and Technology, 41(S1), 344-381.

Light, S. S., \& Dineen, J. W. (1994). Water Control in the Everglades: A Historical Perspective. In S. M. Davis, \& J. C. Ogden, Everglades: the ecosystem and its restoration (pp. 47-84). Boca Raton: St. Lucie Press.

López-Buendía, A., Whateley, M., Bastida , J., \& Urquiola, M. (2007). Origins of mineral matter in peat marsh and peat bog deposits, spain. International Journal of Coal Geology, 71(2), 246-262.

Maltby, E., \& Dugan, P. (1994). Wetland Ecosystem Protection, Management, and Restoration: An International Perspective. In S. M. Davis, \& J. C. Ogden, Everglades: the ecosystem and its restoration (pp. 29-46). Boca Raton, Florida, USA: St. Lucie Press. 
McCarthy, T., Humphries, M., Mahomed, I., Le Roux, P., \& Verhagen, B. (2012). Island forming processes in the Okavango Delta, Botswana. Geomorphology, 179, 249-257.

Meyer, N. A., Breecker, D. O., Young, M. H., \& Litvak, M. E. (2014). Simulating the Effect of vegetation in Formation of Pedogenic Carbonate. Soil Science Society of America Journal, 78(3), 914-924.

National Research Council. (2003). The Ridge and Slough Landscape: Significance, Degradation, Origin, and Maintenance. In National Research Council, Does Water Flow Influence Everglades Landscape Patterns? (pp. 8-15). Washington, DC: The National Academic Press.

Nelson, D. W., \& Sommers, L. E. (1996). Total carbon, organic carbon, and organic matter. In D. Sparks, SSSA Book Series: 5. Methods of soil analysis. Part 3 - chemical methods (pp. 961-1010). Madison, WI: Soil Society of America, Inc.

Nordstrom, D. K., \& Campbell, K. (2014). Modeling low-temperature geochemical processes. In H. Holland, \& K. Turekian, Treatise on Geochemistry, Second Edition (Vol. 7, pp. 27-68). Boulder, Colorado: Elsevier Ltd.

Orem, W. H., Willard, D. A., Lerch, H. E., Bates, A. L., Boylan, A., \& Comm, M. (2002). Nutrient Geochemistry of Sediments from Two Tree Islands in Water Conservation Area 3B, the Everglades, Florida. In Tree islands of the Everglades (pp. 153-186). Springer Netherlands.

Parkhurst, D. L., \& Appelo, C. (2013). Description of input and examples for PHREEQC version 3-A computer program for speciation, batch-reaction, one-dimensional transport, and inverse geochemical calculations. In U.S. Geological Survey Techniques and Methods, book 6 (pp. 43-497). Denver, Colorado: US Geological Survey.

Parkhurst, D. L., Scott, C., \& Breit, G. (1993). Ground-water-quality assessment of the central Oklahoma Aquifer, Oklahoma; geochemical and geohydrologic investigations. In U.S. GEOLOGICAL SURVEY WATER-SUPPLY PAPER 2357. Denver, CO: U.S. Geological Survey.

Parkhurtst, D. L. (1997). Geochemical mole-balance modeling with uncertain data. Water Resources Research, 33(8), 1957-1970.

Patterson, K., \& Finck, R. (1999). Tree Islands of the WCA $3 A$ Aerial photointerpretation and trend analysis project summary report. South Florida Water Management District. West palm Beach: Geonex Corporation.

Plummer, L., Parkhurst, D. L., \& Thorstenson, D. C. (1983). Development of reaction models for ground-water systems. Geochimica et Cosmochimica Acta, 47, 665-686. 
Ramberg, L., \& Wolski, P. (2008). Growing islands and sinking solutes: processes maintaining the endorheic Okavango Delta as a freshwater system. Plant Ecology, 196(2), 215-231.

Reading, H. G. (2009). Sedimentary environments: processes, facies and stratigraphy. Blackwell Science Ltd.

Reddy, K., \& DeLaune, R. (2008). Biogeochemistry of wetlands: science and applications. CRC Press.

Rezanezhad, F., Price, J. S., Quinton, W. L., Lennartz, B., Molojevic, T., \& Van Cappellen, P. (2016). Structure of peat soils and implications for water storage, flow and solute transport: A review update for geochemists. Chemical Geology, 429, 75-84.

Rodriguez, A. F., Serna, A., \& Scinto, L. J. (2014). Soil Accretion Influenced by Elevation, Tree Density, and Substrate on Reconstructed tree Islands. Soil Science Society of America journal, 78(6), 2090-2099.

Sawyer, R. K., \& Wieland, C. C. (1988). The clay mineralogy of calcitic seat earth in the northern Everglades of Florida. Journal of Sedimentary Petrology, 58(1), 81-88.

Schilling, O., Cline, E., \& Dreschel, T. (2013). Critical Flow Patterns for an Everglades Macro-Scale Physical Model. Florida Scientist, 76.

Scholle, P. A., \& Ulmer-Scholle, D. S. (2003). A Color Guide to the Petrography of Carbonate Rocks: Grains, Textures, Porosity, Diagenesis (Vol. 77). Tulsa, Oklahoma: The American Association of Petroleum Geologists.

Schonhoff, B. R. (2015). Gaseous Carbon Emissions (Methane and Carbon Dioxide) From Wetland Soils in a Re-created Everglades Landscape. Florida International University, Earth \& Environment. Miami: FIU Electronic Theses and Dissertations.

Schwadron, M. (2006). Everglades Tree Islands Prehistory: Archaeological Evidence for Regional Holocene Variability and Early Human Settlement. Antiquity, 80(310), 1-6.

Semeniuk, V., \& Meagher, T. (1981). Calcrete in Quaternary coastal dunes in southwestern Australia: A capillary-rise phenomenon associated with plants. Journal of Sedimentary Petrology, 51(1), 47-68.

Sklar, F., \& van der Valk, A. (2002). Tree Islands of the Everglades: an overview. In F. Sklar, \& A. van der Valk, Tree islands of the Everglades (pp. 1-18). Dordrecht, The Netherlands: Kluwer Academic Publishers.

Sklar, F., Coronado-Molina, C., Gras, A., Rutchey, K., Gawlik, D., Grozier, G., . . . McVoy, C. (2004). The Loxahatchee Impoundment Landscape Assessment (LILA). In: 
Chapter 6: Ecological Effects of Hydrology. 2004 Everglades Consolidated Report, South Florida Water Management District, West Palm Beach, FL.

Stofella, S. L., Ross, M. S., Sah, J. P., Price, R. M., Sullivan, P. L., Cline, E. A., \& Scinto, L. J. (2010). Survival and growth responses of eight Everglades tree species along an experimental hydrological gradient on two tree island types. Applied Vegetation Science, 13(4), 439-449.

Sullivan, P. L. (2011). Groundwater-Surface Water Interactions on Tree Islands in the Everglades, South Florida. Florida International University, Earth \& Environment. Miami: FIU Electronic Theses and Dissertations.

Sullivan, P. L., Engel, V., Ross, M. S., \& Price, R. M. (2014b). The influence of vegetation on the hydrodynamics and geomorphology of a tree island in Everglades National Park (Florida, United States). Ecohydrology, 7(2), 727-744.

Sullivan, P. L., Price, R. M., Miralles-Wilhelm, F., Ross, M. S., Scinto, L. J., Dreschel, T. W., . . Cline, E. (2014a). The role of recharge and evapotranspiration as hydraulic drivers of ion concentrations in shallow groundwater on Everglades tree islands, Florida (USA). Hydrological Processes, 28(2), 293-304.

Sullivan, P. L., Price, R. M., Ross, M. S., Scinto, L. J., Stofella, S. L., Cline, E. A., . . Sklar, F. H. (2011). Hydrologic processes on tree islands in the Everglades (Florida, USA): tracking the effects of tree establishment and gorwth. Hydrogeology Journal, 19(2), 367-378.

Sullivan, P. L., Price, R. M., Ross, M. S., Stofella, S. L., Sah, J. P., Scinto, L. J., . . . Sklar, F. H. (2016). Trees: a powerful geomorphic agent governing the landscape evolution of a subtropical wetland. Biogeochemistry, 1-16.

Troxler Gann, T., \& Childers, D. L. (2006). Relationships between hydrology and soils describe vegetation patterns in seasonally flooded tree islands of the southern Everglades, Florida. Plant and soil, 279, 271-286.

Wang, H. F., \& Anderson, M. P. (1982). Introduction to Groundwater Modeling: Finite Difference and Finite Element Methods. Academic Press.

Wetzel, P. R., Sklar, F. H., Coronado, C. A., Troxler, T. G., Krupa, S. L., Sullivan, P. L., ... Orem, W. H. (2011). Biogeochemical Processes on Tree Islands in the Greater Everglades: Initiating a New Paradigm. Critical Reviews in Environmental Science and Technology, 41(S1), 670-701.

Wetzel, P. R., van der Valk, A. G., Newman, S., Coronado, C. A., Troxler-Gann, T. G., Childers, D. L., . . Sklar, F. H. (2009). Heterogeneity of phosphorus distribution in a patterned landscape, the Florida Everglades. Plant Ecology, 200(1), 83-90. 
Wetzel, P. R., van der Valk, A. G., Newman, S., Gawlik, D. E., Troxler, T., CoronadoMolina, C. A., ... Sklar, F. H. (2005). Maintaining tree islands in the Florida Everglades: nutrient redistribution is key. Frontier in Ecology and the Environment, 3(7), 370-376. Wright, V. P. (2007). Calcrete. In D. J. Nash, \& S. J. McLaren, Geochemical Sediments \& Landscapes (pp. 10-45). Malden: Blackwell publishing Ltd. 
APPENDIX A

Water Chemistry Data I: Field Parameters and Anions 


\begin{tabular}{|c|c|c|c|c|c|c|c|c|}
\hline Name Sample & $\begin{array}{c}\text { Date } \\
\text { Collection }\end{array}$ & $\begin{array}{l}\text { Temp. } \\
\left({ }^{\circ} \mathrm{C}\right)\end{array}$ & $\begin{array}{c}\text { Conductivity } \\
(\mu \mathrm{s} / \mathrm{cm})\end{array}$ & pH & $\begin{array}{l}\mathrm{HCO}_{3}^{-} \\
(\mathrm{mg} / \mathrm{L})\end{array}$ & $\underset{(\mathrm{mg} / \mathrm{L})}{\mathrm{Cl}^{-}}$ & $\begin{array}{c}\mathrm{SO}_{4}{ }^{2-} \\
(\mathrm{mg} / \mathrm{L})\end{array}$ & $\begin{array}{c}\mathrm{PO}_{4}^{-} \\
(\mu \mathrm{g} / \mathrm{L})\end{array}$ \\
\hline M1E10S & 18-Oct-13 & 27.2 & 738 & 6.98 & 504.78 & 16.27 & $\mathrm{BDL}$ & 3.10 \\
\hline M1E12R & 18-Oct-13 & 28.1 & 740 & 6.81 & 473.46 & 25.75 & 0.00 & 2.48 \\
\hline M1E4 & 18-Oct-13 & 26.9 & 961 & 6.73 & 408.18 & 45.56 & 0.08 & 114.70 \\
\hline M1E5 & 18-Oct-13 & 26.6 & 1432 & 7.19 & 986.17 & 67.07 & BDL & 13.64 \\
\hline M1W5 & 18-Oct-13 & 25.5 & 1765 & 6.47 & 940.21 & 193.57 & 0.02 & 1.55 \\
\hline M1W5 Shallow & 18-Oct-13 & 26.6 & 1806 & 6.61 & 1120.2 & 135.06 & BDL & 7.44 \\
\hline M1W8 & 18-Oct-13 & 25.5 & 1297 & 6.49 & 624.16 & 116.19 & 0.00 & 1.24 \\
\hline M1W8 Deep & 18-Oct-13 & 25 & 1334 & 6.51 & 711.82 & 126.66 & 0.01 & 1.24 \\
\hline M2E10S & 18-Oct-13 & 26.7 & 682 & 6.73 & 468.37 & 5.30 & BDL & 3.72 \\
\hline M2E12R & 18-Oct-13 & 26.9 & 671 & 6.57 & 401.87 & 34.78 & BDL & 2.48 \\
\hline M2E4 & 18-Oct-13 & 27.4 & 566 & 6.88 & 348.18 & 15.37 & BDL & 2.79 \\
\hline M2E5 & 18-Oct-13 & 26.9 & 859 & 6.75 & 479.76 & 59.71 & BDL & 37.20 \\
\hline M2W5 & 18-Oct-13 & 26.3 & 977 & 6.65 & 567.83 & 28.04 & 0.12 & 0.93 \\
\hline M2W9 & 18-Oct-13 & 26.6 & 817 & 6.43 & 531.01 & 28.62 & BDL & 2.17 \\
\hline M3E10S & 18-Oct-13 & 25.8 & 809 & 6.83 & 560.71 & 15.27 & 0.41 & 0.93 \\
\hline M3E12R & 18-Oct-13 & 26.4 & 547 & 6.93 & 308.11 & 25.96 & BDL & 0.93 \\
\hline M3E4 & 18-Oct-13 & 26.8 & 922 & 6.51 & 489.73 & 35.07 & 0.09 & 1.86 \\
\hline M3E5 & 18-Oct-13 & 26.5 & 2923 & 6.68 & 181.21 & 290.04 & 0.15 & 3.41 \\
\hline M3E8 Deep & 18-Oct-13 & 25.6 & 2063 & 7.16 & 1243.4 & 173.21 & 0.03 & 2.17 \\
\hline M3W5 & 18-Oct-13 & 26.1 & 1055 & 6.47 & 305.67 & 76.65 & BDL & 0.93 \\
\hline M3W9 & 18-Oct-13 & 27.4 & 1006 & 6.53 & 613.38 & 28.48 & 0.01 & 0.93 \\
\hline M4E10S & 18-Oct-13 & 26.8 & 614 & 7.17 & 412.45 & 11.19 & BDL & 0.93 \\
\hline M4E12R & 18-Oct-13 & 28 & 642 & 6.83 & 383.97 & 21.79 & 0.00 & 1.86 \\
\hline M4E4 & 18-Oct-13 & 27 & 802 & 7.17 & 489.73 & 39.74 & BDL & 1.86 \\
\hline M4E5 & 18-Oct-13 & 26.3 & 1276 & 6.98 & 181.21 & 69.44 & 0.72 & 3.41 \\
\hline
\end{tabular}




\begin{tabular}{|c|c|c|c|c|c|c|c|c|}
\hline Name Sample & $\begin{array}{c}\text { Date } \\
\text { Collection }\end{array}$ & $\begin{array}{c}\text { Temp. } \\
\left({ }^{\circ} \mathrm{C}\right)\end{array}$ & $\begin{array}{c}\text { Conductivity } \\
(\mu \mathrm{s} / \mathrm{cm})\end{array}$ & $\mathbf{p H}$ & $\begin{array}{l}\mathrm{HCO}_{3}^{-} \\
(\mathrm{mg} / \mathrm{L})\end{array}$ & $\underset{(\mathrm{mg} / \mathrm{L})}{\mathrm{Cl}^{-}}$ & $\begin{array}{c}\mathrm{SO}_{4}{ }^{2-} \\
(\mathrm{mg} / \mathrm{L})\end{array}$ & $\begin{array}{c}\mathbf{P O}_{4}^{-} \\
(\mu \mathrm{g} / \mathrm{L})\end{array}$ \\
\hline M4W5 & 18-Oct-13 & 25.8 & 1833 & 6.47 & 509.25 & 155.09 & 0.01 & 0.93 \\
\hline M4W9 & 18-Oct-13 & 27.2 & 749 & 6.42 & 425.46 & 0.57 & BDL & 7.13 \\
\hline M1ESW & 18-Oct-13 & 26.8 & 349 & 7.71 & 192.6 & 16.52 & BDL & BDL \\
\hline M1WSW & 18-Oct-13 & 26.5 & 323 & 7.61 & 204.19 & 16.95 & BDL & BDL \\
\hline M2ESW & 18-Oct-13 & 27.2 & 243 & 7.46 & 131.79 & 15.59 & 0.00 & BDL \\
\hline M2WSW & 18-Oct-13 & 26.6 & 329 & 7.53 & 217.72 & 16.90 & 0.00 & $\mathrm{BDL}$ \\
\hline M3ESW & 18-Oct-13 & 26.8 & 315 & 7.31 & 192.29 & 17.38 & BDL & BDL \\
\hline M3WSW & 18-Oct-13 & 27.2 & 301 & 7.48 & 162.6 & 17.48 & 0.00 & $\mathrm{BDL}$ \\
\hline M4ESW & 18-Oct-13 & 26.1 & 274 & 7.54 & 166.67 & 17.30 & 0.00 & BDL \\
\hline M4WSW & 18-Oct-13 & 26.1 & 273 & 7.52 & 178.92 & 16.74 & 0.00 & BDL \\
\hline M1E10S & 14-May-14 & 24.5 & 705 & 6.73 & 507.25 & 14.53 & BDL & BDL \\
\hline M1E12R & 14-May-14 & 24.8 & 701 & 6.51 & 458.03 & 19.14 & BDL & BDL \\
\hline M1E4 & 14-May-14 & 24.5 & 767 & 6.71 & 442.98 & 52.24 & 0.18 & 30.52 \\
\hline M1E5 & 14-May-14 & 24.5 & 1109 & 6.59 & 699.05 & 53.91 & 1.71 & 7.27 \\
\hline M1W5 & 14-May-14 & 23.8 & 1665 & 6.65 & 915.86 & 176.23 & BDL & 4.17 \\
\hline M1W8 & 14-May-14 & 23.7 & 1088 & 6.57 & 631.52 & 83.89 & BDL & BDL \\
\hline M1W8 Deep & 14-May-14 & 23.4 & 1274 & 6.56 & 685.83 & 129.07 & BDL & 4.79 \\
\hline M2E10S & 14-May-14 & 24.4 & 743 & 6.75 & 485.29 & 6.12 & $\mathrm{BDL}$ & BDL \\
\hline M2E12R & 14-May-14 & 25.7 & 681 & 6.49 & 416.13 & 19.95 & BDL & BDL \\
\hline M2E4 & 14-May-14 & 23.9 & 433.1 & 6.26 & 245.69 & 18.96 & BDL & BDL \\
\hline M2E5 & 14-May-14 & 24.2 & 1028 & 6.29 & 468.41 & 108.78 & BDL & 11.61 \\
\hline M2W5 & 14-May-14 & 24 & 899 & 6.49 & 561.76 & 35.43 & BDL & BDL \\
\hline M2W9 & 14-May-14 & 24.9 & 818 & 6.42 & 484.88 & 40.76 & BDL & BDL \\
\hline M3E10S & 14-May-14 & 25.5 & 839 & 7.02 & 537.76 & 12.74 & BDL & BDL \\
\hline M3E12R & 14-May-14 & 24.2 & 545 & 6.47 & 305.9 & 23.34 & BDL & BDL \\
\hline M3E4 & 14-May-14 & 25.1 & 683 & 6.46 & 308.54 & 34.18 & 1.26 & $\mathrm{BDL}$ \\
\hline M3E5 & 14-May-14 & 25 & 2181 & 6.78 & 1061.3 & 209.08 & 6.57 & BDL \\
\hline
\end{tabular}




\begin{tabular}{|c|c|c|c|c|c|c|c|c|}
\hline Name Sample & $\begin{array}{c}\text { Date } \\
\text { Collection }\end{array}$ & $\begin{array}{l}\text { Temp. } \\
\left({ }^{\circ} \mathrm{C}\right)\end{array}$ & $\begin{array}{l}\text { Conductivity } \\
(\mu \mathrm{s} / \mathrm{cm})\end{array}$ & pH & $\begin{array}{l}\mathrm{HCO}_{3}^{-} \\
(\mathrm{mg} / \mathrm{L})\end{array}$ & $\underset{(\mathrm{mg} / \mathrm{L})}{\mathrm{Cl}^{-}}$ & $\begin{array}{l}\mathrm{SO}_{4}{ }^{2-} \\
(\mathrm{mg} / \mathrm{L})\end{array}$ & $\begin{array}{c}\mathrm{PO}_{4}^{-} \\
(\mu \mathrm{g} / \mathrm{L})\end{array}$ \\
\hline M3E8 Deep & 14-May-14 & 24.6 & 1621 & 7.06 & 866.85 & 121.64 & BDL & BDL \\
\hline M3W5 & 14-Мay-14 & 24.1 & 946 & 6.57 & 553.42 & 64.56 & BDL & BDL \\
\hline M3W9 & 14-May-14 & 24.6 & 879 & 6.64 & 546.91 & 34.98 & 0.51 & BDL \\
\hline M4E10S & 14-May-14 & 24.6 & 587 & 6.82 & 361.02 & 19.73 & $\mathrm{BDL}$ & $\mathrm{BDL}$ \\
\hline M4E12R & 14-May-14 & 24.1 & 552 & 6.37 & 359.39 & 16.39 & $\mathrm{BDL}$ & $\mathrm{BDL}$ \\
\hline M4E4 & 14-May-14 & 24.3 & 577 & 6.46 & 273.56 & 48.44 & BDL & BDL \\
\hline M4E5 & 14-May-14 & 24.3 & 1180 & 6.71 & 748.47 & 61.52 & 3.20 & 4.17 \\
\hline M4W5 & 14-Мay-14 & 24.4 & 1326 & 6.55 & 791.8 & 83.79 & BDL & BDL \\
\hline M4W9 & 14-May-14 & 24.7 & 639 & 6.53 & 363.86 & 23.91 & 0.29 & BDL \\
\hline M1ESW & 14-May-14 & 26.7 & 416 & 8.07 & 189.15 & 35.17 & 0.00 & $\mathrm{BDL}$ \\
\hline M1WSW & 14-Мay-14 & 28.4 & 432 & 8.07 & 154.37 & 34.52 & 0.00 & BDL \\
\hline M2ESW & 14-May-14 & 23.9 & 585 & 7.04 & 294.51 & 36.77 & 0.04 & $\mathrm{BDL}$ \\
\hline M2WSW & 14-May-14 & 25.5 & 568 & 7.23 & 271.52 & 23.90 & 0.10 & BDL \\
\hline M3ESW & 14-Мay-14 & 25.2 & 441 & 7.51 & 204 & 28.68 & 0.00 & BDL \\
\hline M3WSW & 14-May-14 & 26.8 & 418 & 7.54 & 222.51 & 27.77 & 0.00 & BDL \\
\hline M4ESW & 14-May-14 & 26.9 & 394 & 7.54 & 202.58 & 34.52 & 0.00 & BDL \\
\hline M4WSW & 14-May-14 & 30.2 & 473 & 7.62 & 197.9 & 6.12 & 0.00 & $\mathrm{BDL}$ \\
\hline M1E10S & 15-Oct-14 & 26.7 & 855 & 6.61 & 514.58 & 23.97 & 0.06 & $\mathrm{BDL}$ \\
\hline M1E12R & $15-O c t-14$ & 27 & 755 & 6.52 & 451.93 & 26.72 & BDL & BDL \\
\hline M1E4 & 15 -Oct-14 & 26.5 & 967 & 6.54 & 569.29 & 46.77 & 0.20 & 46.74 \\
\hline M1E5 & $15-O c t-14$ & 25.9 & 1797 & 6.65 & 1040.3 & 101.08 & 5.40 & BDL \\
\hline M1W5 & 15 -Oct-14 & 25.4 & 1781 & 6.69 & 887.18 & 170.58 & $\mathrm{BDL}$ & 4.21 \\
\hline M1W5 Shallow & 15 -Oct-14 & 25.7 & 2430 & 6.88 & 1217.7 & 249.36 & $\mathrm{BDL}$ & 24.05 \\
\hline M1W8 & 15-Oct-14 & 25.4 & 1515 & 6.58 & 737.08 & 144.02 & BDL & 5.76 \\
\hline M1W8 Deep & 15-Oct-14 & 25.4 & 1861 & 6.71 & 946.98 & 223.07 & BDL & 3.90 \\
\hline M2E10S & $15-O c t-14$ & 26.9 & 781 & 6.76 & 476.74 & 14.71 & $\mathrm{BDL}$ & BDL \\
\hline M2E12R & 15-Oct-14 & 27.2 & 659 & 6.6 & 375.66 & 21.66 & BDL & 5.14 \\
\hline
\end{tabular}




\begin{tabular}{|c|c|c|c|c|c|c|c|c|}
\hline Name Sample & $\begin{array}{c}\text { Date } \\
\text { Collection }\end{array}$ & $\begin{array}{c}\text { Temp. } \\
\left({ }^{\circ} \mathrm{C}\right)\end{array}$ & $\begin{array}{c}\text { Conductivity } \\
(\mu \mathrm{s} / \mathrm{cm})\end{array}$ & pH & $\begin{array}{l}\mathrm{HCO}_{3}^{-} \\
(\mathrm{mg} / \mathrm{L})\end{array}$ & $\underset{(\mathrm{mg} / \mathrm{L})}{\mathrm{Cl}^{-}}$ & $\begin{array}{l}\mathrm{SO}_{4}{ }^{2-} \\
(\mathrm{mg} / \mathrm{L})\end{array}$ & $\begin{array}{c}\mathrm{PO}_{4}^{-} \\
(\mu \mathrm{g} / \mathrm{L})\end{array}$ \\
\hline M2E4 & 15-Oct-14 & 26.6 & 539 & 6.64 & 318.91 & 15.57 & BDL & 4.52 \\
\hline M2E5 & 15-Oct-14 & 25.7 & 1309 & 6.56 & 565.63 & 128.25 & 0.04 & 69.62 \\
\hline M2W5 & 15-Oct-14 & 26.5 & 1176 & 6.79 & 714.1 & 49.10 & 7.34 & BDL \\
\hline M2W9 & 15-Oct-14 & 27.2 & 825 & 6.59 & 473.49 & 30.55 & BDL & BDL \\
\hline M3E10S & 15-Oct-14 & 26.3 & 880 & 6.99 & 550.17 & 11.99 & BDL & BDL \\
\hline M3E12R & 15-Oct-14 & 26.2 & 566 & 6.54 & 300.41 & 23.56 & BDL & BDL \\
\hline M3E4 & 15-Oct-14 & 26.7 & 976 & 6.55 & 556.47 & 42.13 & BDL & 3.59 \\
\hline M3E5 & 15-Oct-14 & 25.5 & 2921 & 6.86 & 1544.1 & 321.20 & 0.09 & 30.87 \\
\hline M3E8 Deep & $15-O c t-14$ & 25.5 & 2410 & 7.11 & 1191.7 & 252.88 & 0.30 & BDL \\
\hline M3W5 & 15-Oct-14 & 25.8 & 1172 & 6.64 & 626.03 & 89.91 & 2.26 & 3.28 \\
\hline M3W9 & 15-Oct-14 & 27.1 & 1061 & 6.66 & 634.98 & 33.16 & 0.11 & 3.90 \\
\hline M4E10S & 15-Oct-14 & 27 & 703 & 6.79 & 398.03 & 22.19 & BDL & BDL \\
\hline M4E12R & 15-Oct-14 & 26.7 & 623 & 6.6 & 360.41 & 26.53 & 0.03 & 5.45 \\
\hline M4E4 & 15-Oct-14 & 26.6 & 732 & 6.73 & 475.52 & 33.71 & BDL & 4.21 \\
\hline M4E5 & $15-O c t-14$ & 25.7 & 1438 & 6.87 & 851.39 & 76.74 & 9.83 & 11.03 \\
\hline M4W5 & 15 -Oct-14 & 25.4 & 2080 & 6.78 & 1086.5 & 213.89 & 0.09 & BDL \\
\hline M4W9 & 15-Oct-14 & 26.6 & 776 & 6.54 & 446.64 & 32.12 & 0.09 & 6.38 \\
\hline M1ESW & 15-Oct-14 & 28.5 & 270.5 & 7.06 & 142.58 & 14.65 & BDL & 15.99 \\
\hline M1WSW & 15-Oct-14 & 27.6 & 309.5 & 7.17 & 153.97 & 16.71 & 0.26 & BDL \\
\hline M2ESW & $15-O c t-14$ & 28.4 & 330.1 & 6.93 & 174.71 & 15.83 & BDL & BDL \\
\hline M2WSW & 15 -Oct-14 & 29.5 & 342.7 & 7.05 & 157.83 & 16.21 & BDL & BDL \\
\hline M3ESW & $15-O c t-14$ & 26 & 319.7 & 6.77 & 172.27 & 14.60 & BDL & BDL \\
\hline M3WSW & 15-Oct-14 & 27.2 & 347 & 6.92 & 187.93 & 16.03 & BDL & $\mathrm{BDL}$ \\
\hline M4ESW & 15-Oct-14 & 25.8 & 319.9 & 6.83 & 172.27 & 17.08 & BDL & BDL \\
\hline M4WSW & 15 -Oct-14 & 26.6 & 341.1 & 7.01 & 186.1 & 16.53 & BDL & BDL \\
\hline M1E10S & 22-May-15 & 26.3 & 919 & 6.67 & 547.12 & 22.23 & BDL & 1.66 \\
\hline M1E12R & 22-Маy-15 & 25.5 & 718 & 6.92 & 398.85 & 21.26 & BDL & 1.97 \\
\hline
\end{tabular}




\begin{tabular}{|c|c|c|c|c|c|c|c|c|}
\hline Name Sample & $\begin{array}{c}\text { Date } \\
\text { Collection }\end{array}$ & $\begin{array}{c}\text { Temp. } \\
\left({ }^{\circ} \mathrm{C}\right)\end{array}$ & $\begin{array}{c}\text { Conductivity } \\
(\mu \mathrm{s} / \mathrm{cm})\end{array}$ & $\mathbf{p H}$ & $\begin{array}{l}\mathrm{HCO}_{3}^{-} \\
(\mathrm{mg} / \mathrm{L})\end{array}$ & $\begin{array}{c}\mathrm{Cl}^{-} \\
(\mathrm{mg} / \mathrm{L})\end{array}$ & $\begin{array}{c}\mathrm{SO}_{4}{ }^{2-} \\
(\mathrm{mg} / \mathrm{L})\end{array}$ & $\begin{array}{c}\mathrm{PO}_{4}^{-} \\
(\mu \mathrm{g} / \mathrm{L})\end{array}$ \\
\hline M1E4 & 22-May-15 & 24.4 & 1099 & 6.49 & 641.49 & 65.87 & $\mathrm{BDL}$ & 0.42 \\
\hline M1E5 & 22-May-15 & 24.9 & 1070 & 7.05 & 622.17 & 146.69 & 4.36 & 0.11 \\
\hline M1W5 & 22-May-15 & 25 & 1536 & 6.57 & 804.2 & 150.04 & BDL & 21.81 \\
\hline M1W5 Shallow & 22-May-15 & 24.4 & 1512 & 7.43 & 915.66 & 173.85 & BDL & 0.11 \\
\hline M1W8 & 22-May-15 & 24.1 & 1128 & 6.85 & 613.02 & 81.76 & BDL & 1.66 \\
\hline M1W8 Deep & 22-May-15 & 23.8 & 750 & 6.61 & 687.86 & 132.38 & BDL & 1.04 \\
\hline M2E10S & 22-May-15 & 25.7 & 834 & 6.59 & 513.76 & 13.60 & BDL & 0.42 \\
\hline M2E12R & 22-May-15 & 24.8 & 636 & 6.47 & 369.56 & 21.24 & $\mathrm{BDL}$ & 3.52 \\
\hline M2E4 & 22-May-15 & 24.2 & 549 & 6.28 & 338.44 & 31.40 & BDL & 1.35 \\
\hline M2E5 & 22-May-15 & 23.7 & 1101 & 6.3 & 485.49 & 113.74 & BDL & 14.68 \\
\hline M2W5 & 22-May-15 & 23.6 & 950 & 6.98 & 573.97 & 42.60 & 0.07 & 0.11 \\
\hline M2W9 & 22-May-15 & 23.6 & 741 & 6.36 & 418.37 & 39.70 & BDL & 1.04 \\
\hline M3E10S & 22-May-15 & 25.3 & 896 & 7.81 & 569.49 & 10.66 & BDL & 1.04 \\
\hline M3E12R & 22-May-15 & 24.4 & 556 & 6.73 & 322.17 & 26.55 & 0.14 & 0.11 \\
\hline M3E4 & 22-May-15 & 25.9 & 583 & 6.28 & 267.05 & 42.87 & 0.79 & 1.66 \\
\hline M3E5 & 22-Мay-15 & & & 7.87 & 599.39 & 147.81 & 1.18 & 1.97 \\
\hline M3E8 Deep & 22-May-15 & 24.6 & 1595 & 7.69 & 876 & 141.12 & 1.18 & 1.66 \\
\hline M3W5 & 22-May-15 & 25.2 & 1281 & 6.56 & 542.64 & 73.92 & BDL & 0.11 \\
\hline M3W9 & 22-May-15 & 25.1 & 926 & 6.68 & 560.34 & 36.41 & BDL & 0.42 \\
\hline M4E10S & 22-May-15 & 25.5 & 695 & 6.67 & 398.44 & 21.74 & BDL & 0.42 \\
\hline M4E12R & 22-May-15 & 25.4 & 603 & 6.36 & 337.02 & 19.37 & BDL & 0.11 \\
\hline M4E4 & 22-May-15 & 25.5 & 642 & 6.29 & 295.73 & 48.26 & BDL & 0.11 \\
\hline M4E5 & 22-May-15 & 24.5 & 1281 & 7.13 & 717.56 & 66.28 & BDL & 0.42 \\
\hline M4W5 & 22-Мay-15 & 24.2 & 1243 & 6.55 & 669.15 & 74.00 & BDL & 0.11 \\
\hline M4W9 & 22-May-15 & 24.6 & 765 & 6.57 & 437.08 & 31.03 & 0.05 & 0.11 \\
\hline M1ESW & 22-May-15 & 28.1 & 658 & 7.1 & 284.95 & 40.33 & 0.08 & BDL \\
\hline M1WSW & 22-May-15 & 28.1 & 658 & 7.1 & 284.95 & 40.33 & 0.08 & $\mathrm{BDL}$ \\
\hline
\end{tabular}




\begin{tabular}{|c|c|c|c|c|c|c|c|c|}
\hline Name Sample & $\begin{array}{c}\text { Date } \\
\text { Collection }\end{array}$ & $\begin{array}{c}\text { Temp. } \\
\left({ }^{\circ} \mathrm{C}\right)\end{array}$ & $\begin{array}{l}\text { Conductivity } \\
(\mu \mathrm{s} / \mathrm{cm})\end{array}$ & pH & $\begin{array}{l}\mathrm{HCO}_{3}{ }^{-} \\
(\mathrm{mg} / \mathrm{L})\end{array}$ & $\underset{(\mathrm{mg} / \mathrm{L})}{\mathrm{Cl}^{-}}$ & $\underset{(\mathrm{mg} / \mathrm{L})}{\mathrm{SO}_{4}{ }^{2-}}$ & $\begin{array}{c}\mathrm{PO}_{4}^{-} \\
(\mu \mathrm{g} / \mathrm{L})\end{array}$ \\
\hline M2ESW & 22-May-15 & 29.6 & 631 & 7.19 & 295.12 & 48.10 & BDL & $\mathrm{BDL}$ \\
\hline M2WSW & 22-Мay-15 & 32.9 & 606 & 7.57 & 231.25 & 43.11 & BDL & BDL \\
\hline M3ESW & 22-May-15 & 29.7 & 613 & 7.52 & 282.3 & 37.04 & BDL & BDL \\
\hline M3WSW & 22-May-15 & 29.7 & 613 & 7.52 & 282.3 & 38.04 & BDL & BDL \\
\hline M4ESW & 22-May-15 & 27.4 & 594 & 7.32 & 249.56 & 46.07 & BDL & BDL \\
\hline M4WSW & 22-Мay-15 & 27.4 & 594 & 7.32 & 249.56 & 47.07 & BDL & BDL \\
\hline M1E10S & $20-$ Oct-15 & 26.5 & 882 & 6.59 & 493.02 & 24.85 & 0.09 & 2.57 \\
\hline M1E12R & $20-$-Oct-15 & 26.6 & 651 & 6.46 & 342.3 & 28.76 & BDL & 2.88 \\
\hline M1E4 & $20-$ Oct-15 & 25.8 & 1168 & 6.54 & 656.54 & 79.90 & 4.28 & 3.50 \\
\hline M1E5 & $20-$-Oct-15 & 25.3 & 2173 & 6.77 & 950.85 & 177.92 & 94.55 & 3.81 \\
\hline M1W5 & $20-$ Oct-15 & 25.5 & 1391 & 6.56 & 706.58 & 121.54 & 0.11 & 8.15 \\
\hline M1W5 Shallow & $20-$ Oct-15 & 25.1 & 2685 & 6.73 & 1094.4 & 400.87 & 59.96 & 5.05 \\
\hline M1W8 & $20-$ Oct-15 & 25.3 & 1294 & 6.56 & 641.08 & 118.33 & 0.97 & 5.67 \\
\hline M1W8 Deep & $20-$ Oct-15 & 25.4 & 1173 & 6.53 & 733.42 & 216.76 & 17.52 & 6.29 \\
\hline M2E10S & $20-$ Oct-15 & 27.2 & 852 & 6.6 & 497.9 & 23.39 & BDL & 1.33 \\
\hline M2E12R & $20-$ Oct-15 & 26.7 & 644 & 6.46 & 358.58 & 26.15 & $\mathrm{BDL}$ & 2.26 \\
\hline M2E4 & $20-$ Oct-15 & 26.3 & 654 & 6.57 & 356.75 & 31.58 & 0.14 & 3.50 \\
\hline M2E5 & 20-Oct-15 & 25.4 & 1322 & 6.41 & 531.66 & 162.04 & 10.72 & 8.15 \\
\hline M2W5 & $20-$ Oct-15 & 25.3 & 1272 & 6.71 & 556.27 & 78.94 & 62.11 & 0.71 \\
\hline M2W9 & $20-$ Oct-15 & 26.1 & 907 & 6.37 & 511.52 & 55.27 & 0.32 & 2.88 \\
\hline M3E10S & $20-$ Oct-15 & 26 & 916 & 7.57 & 585.35 & 12.74 & 0.04 & 0.09 \\
\hline M3E12R & $20-$ Oct-15 & 26.1 & 553 & 7.23 & 299.59 & 22.98 & BDL & 0.40 \\
\hline M3E4 & 20-Oct-15 & 26 & 905 & 6.34 & 455.19 & 62.03 & 0.95 & 2.88 \\
\hline M3E5 & $20-$ Oct-15 & 24.6 & 2522 & 6.61 & 998.24 & 328.53 & 80.59 & 10.63 \\
\hline M3E8 Deep & $20-$ Oct-15 & 25.3 & 2692 & 7.27 & 860.54 & 393.57 & 134.77 & 0.40 \\
\hline M3W5 & $20-$ Oct-15 & 25.8 & 1309 & 6.51 & 548.54 & 101.60 & 25.95 & 0.40 \\
\hline M3W9 & $20-$ Oct-15 & 26.5 & 1063 & 6.67 & 668.95 & 37.81 & 0.22 & 0.09 \\
\hline
\end{tabular}




\begin{tabular}{|c|c|c|c|c|c|c|c|c|}
\hline Name Sample & $\begin{array}{c}\text { Date } \\
\text { Collection }\end{array}$ & $\begin{array}{l}\text { Temp. } \\
\left({ }^{\circ} \mathrm{C}\right)\end{array}$ & $\begin{array}{c}\text { Conductivity } \\
(\mu \mathrm{s} / \mathrm{cm})\end{array}$ & pH & $\begin{array}{l}\mathrm{HCO}_{3}^{-} \\
(\mathrm{mg} / \mathrm{L})\end{array}$ & $\begin{array}{c}\mathrm{Cl}^{-} \\
(\mathrm{mg} / \mathrm{L})\end{array}$ & $\begin{array}{l}\mathrm{SO}_{4}{ }^{2-} \\
(\mathrm{mg} / \mathrm{L})\end{array}$ & $\begin{array}{c}\mathrm{PO}_{4}^{-} \\
(\mu \mathrm{g} / \mathrm{L})\end{array}$ \\
\hline M4E10S & $20-$ Oct-15 & 27.1 & 776 & 6.63 & 418.17 & 32.40 & $\mathrm{BDL}$ & 1.33 \\
\hline M4E12R & $20-$-Oct-15 & 26.9 & 545 & 6.21 & 268.88 & 28.05 & BDL & 0.71 \\
\hline M4E4 & 20-Oct-15 & 26.5 & 787 & 6.6 & 485.69 & 55.24 & 2.74 & 1.95 \\
\hline M4E5 & $20-$ Oct-15 & 25.5 & 1605 & 6.96 & 712.88 & 123.26 & 70.15 & 4.12 \\
\hline M4W5 & 20-Oct-15 & 25.5 & 1186 & 6.43 & 684 & 64.68 & 0.03 & 1.33 \\
\hline M4W9 & $20-$-Oct-15 & 26.1 & 688 & 6.38 & 318.91 & 42.03 & 0.10 & 3.50 \\
\hline M1ESW & $20-$-Oct-15 & 24 & 378.5 & 7.29 & 197.9 & 27.21 & 0.17 & BDL \\
\hline M1WSW & 20-Oct-15 & 24.3 & 337 & 7.53 & 203.59 & 27.40 & 0.20 & $\mathrm{BDL}$ \\
\hline M2ESW & $20-$ Oct-15 & 25.4 & 340 & 6.67 & 161.08 & 26.05 & BDL & BDL \\
\hline M2WSW & 20-Oct-15 & 25.2 & 358.4 & 7.45 & 177.56 & 27.99 & 0.16 & BDL \\
\hline M3ESW & $20-$ Oct-15 & 24.5 & 367.2 & 7.25 & 187.73 & 26.65 & 0.48 & BDL \\
\hline M3WSW & 20 -Oct-15 & 27.1 & 402.5 & 7.08 & 193.83 & 26.34 & 0.06 & BDL \\
\hline M4ESW & $20-$-Oct-15 & 26.1 & 373.6 & 7.56 & 169.22 & 29.06 & 0.12 & BDL \\
\hline M4WSW & $20-$ Oct-15 & 25.3 & 397.3 & 7.17 & 187.73 & 28.73 & 0.15 & BDL \\
\hline
\end{tabular}

4, 8, 9 = Edge 5 = Center $\mathrm{S}=$ Slough $; \mathrm{R}=$ Ridge SW = Surface Water BDL = Below Detection Limit 


\section{APPENDIX B}

Water Chemistry Data II: Cations, Nutrients, and Stable Isotopes 


\begin{tabular}{|c|c|c|c|c|c|c|c|c|c|c|}
\hline Name Sample & $\begin{array}{c}\text { Date } \\
\text { Collection }\end{array}$ & $\begin{array}{c}\mathrm{Na}^{+} \\
(\mathrm{mg} / \mathrm{L})\end{array}$ & $\begin{array}{c}\mathbf{K}^{+} \\
(\mathbf{m g} / \mathbf{l})\end{array}$ & $\begin{array}{c}\mathrm{Mg}^{2+} \\
(\mathrm{mg} / \mathrm{L})\end{array}$ & $\begin{array}{c}\mathrm{Ca}^{2+} \\
(\mathrm{mg} / \mathrm{l})\end{array}$ & $\begin{array}{c}\mathrm{NH}_{4}{ }^{+} \\
(\mathrm{mg} / \mathrm{L})\end{array}$ & $\begin{array}{c}\mathbf{T P} \\
(\mathrm{mg} / \mathrm{L})\end{array}$ & $\begin{array}{c}\text { TOC } \\
(\mathrm{mg} / \mathrm{L})\end{array}$ & $\delta^{18} \mathrm{O} \%$ & $\delta \mathrm{D} \%$ \\
\hline M1E10S & 18-Oct-13 & 21.50 & 1.52 & 11.47 & 136.82 & 4.86 & 16.73 & 25.35 & 1.40 & 6.66 \\
\hline M1E12R & 18-Oct-13 & 23.37 & 0.30 & 12.49 & 135.29 & 0.05 & 18.25 & 28.59 & 1.32 & 7.85 \\
\hline M1E4 & 18-Oct-13 & 34.41 & 1.46 & 10.19 & 178.15 & 9.28 & 231.01 & 62.35 & 0.21 & 0.68 \\
\hline M1E5 & 18-Oct-13 & 45.61 & 3.50 & 20.05 & 264.57 & 13.57 & 76.93 & 54.83 & -1.28 & -5.43 \\
\hline M1W5 & 18-Oct-13 & 87.00 & 2.27 & 22.08 & 316.52 & 4.31 & 42.44 & 54.94 & -1.54 & -2.61 \\
\hline M1W5 Shallow & 18-Oct-13 & 89.24 & 0.38 & 21.41 & 365.04 & 0.84 & 67.58 & 76.83 & -1.78 & -5.28 \\
\hline M1W8 & 18-Oct-13 & 61.69 & 3.58 & 15.80 & 229.87 & 5.78 & 19.27 & 48.92 & -0.74 & 0.21 \\
\hline M1W8 Deep & 18-Oct-13 & 65.86 & 3.52 & 15.53 & 228.14 & 1.90 & 24.94 & 42.77 & 0.11 & 3.87 \\
\hline M2E10S & 18-Oct-13 & 7.67 & 0.63 & 6.71 & 135.11 & 4.32 & 14.68 & 13.46 & 1.46 & 5.22 \\
\hline M2E12R & 18-Oct-13 & 27.35 & 0.50 & 7.87 & 119.63 & 0.13 & 12.31 & 29.67 & 0.91 & 6.41 \\
\hline M2E4 & 18-Oct-13 & 13.58 & 0.18 & 4.46 & 111.25 & 0.39 & 13.61 & 18.60 & 2.15 & 1.65 \\
\hline M2E5 & 18-Oct-13 & 42.63 & 0.46 & 9.46 & 151.60 & 6.29 & 97.14 & 99.89 & -0.74 & -5.45 \\
\hline M2W5 & 18-Oct-13 & 25.78 & 1.89 & 11.27 & 200.58 & 1.79 & 13.92 & 41.33 & -0.64 & -6.88 \\
\hline M2W9 & 18-Oct-13 & 25.86 & 0.21 & 9.60 & 161.72 & 0.86 & 16.74 & 38.49 & 2.14 & 6.38 \\
\hline M3E10S & 18-Oct-13 & 24.35 & 1.28 & 10.37 & 150.21 & 5.60 & 13.83 & 27.97 & 1.67 & 9.73 \\
\hline M3E12R & 18-Oct-13 & 18.93 & 0.46 & 8.22 & 92.08 & 0.00 & 9.58 & 43.95 & 0.54 & 3.08 \\
\hline M3E4 & 18-Oct-13 & 25.62 & 0.22 & 10.43 & 171.85 & 1.93 & 29.97 & 56.65 & 0.03 & 2.59 \\
\hline M3E5 & 18-Oct-13 & 172.01 & 2.24 & 37.57 & 509.24 & 3.26 & 131.42 & 184.69 & -1.33 & -4.40 \\
\hline M3E8 Deep & 18-Oct-13 & 110.56 & 3.28 & 28.26 & 403.03 & 5.91 & 47.03 & 142.89 & -1.25 & -1.51 \\
\hline M3W5 & 18-Oct-13 & 51.23 & 7.91 & 12.42 & 177.09 & 4.17 & 27.37 & 35.21 & 1.97 & 7.15 \\
\hline M3W9 & 18-Oct-13 & 25.72 & 1.18 & 9.86 & 195.89 & 0.99 & 18.20 & 32.39 & 0.13 & 3.90 \\
\hline M4E10S & 18-Oct-13 & 9.46 & 0.55 & 6.98 & 121.79 & 3.09 & 9.44 & 13.12 & 1.08 & 8.49 \\
\hline M4E12R & 18-Oct-13 & 16.92 & 0.16 & 10.67 & 112.52 & 0.00 & 11.01 & 21.55 & 1.25 & 9.01 \\
\hline M4E4 & 18-Oct-13 & 28.59 & 0.92 & 8.01 & 151.23 & 1.93 & 20.14 & 30.09 & 0.62 & 3.67 \\
\hline M4E5 & 18-Oct-13 & 45.50 & 2.18 & 19.44 & 253.68 & 3.26 & 78.31 & 53.65 & -1.59 & -2.44 \\
\hline
\end{tabular}




\begin{tabular}{|c|c|c|c|c|c|c|c|c|c|c|}
\hline Name Sample & $\begin{array}{c}\text { Date } \\
\text { Collection }\end{array}$ & $\begin{array}{c}\mathrm{Na}^{+} \\
(\mathrm{mg} / \mathrm{L})\end{array}$ & $\begin{array}{c}\mathbf{K}^{+} \\
(\mathbf{m g} / \mathbf{l})\end{array}$ & $\begin{array}{c}\mathrm{Mg}^{2+} \\
(\mathrm{mg} / \mathrm{L})\end{array}$ & $\begin{array}{c}\mathrm{Ca}^{2+} \\
(\mathrm{mg} / \mathrm{l})\end{array}$ & $\begin{array}{c}\mathrm{NH}_{4}^{+} \\
(\mathrm{mg} / \mathrm{L})\end{array}$ & $\begin{array}{c}\text { TP } \\
(\mathrm{mg} / \mathrm{L})\end{array}$ & $\begin{array}{c}\text { TOC } \\
(\mathrm{mg} / \mathrm{L})\end{array}$ & $\delta^{18} \mathrm{O} \%$ & $\delta \mathrm{D} \%$ \\
\hline M4W5 & 18-Oct-13 & 88.08 & 5.57 & 24.00 & 327.14 & 4.44 & 25.67 & 87.30 & -1.14 & -5.13 \\
\hline M4W9 & $18-$ Oct-13 & 20.89 & 0.53 & 7.78 & 131.87 & 3.08 & 34.15 & 46.17 & 0.63 & 3.99 \\
\hline M1ESW & 23-Oct-13 & 13.04 & 0.80 & 2.91 & 56.74 & BDL & 7.09 & 12.45 & 13.18 & 2.87 \\
\hline M1WSW & 23-Oct-13 & 13.24 & 0.79 & 2.92 & 53.11 & 0.01 & 5.12 & 12.12 & 12.71 & 2.88 \\
\hline M2ESW & 23-Oct-13 & 11.02 & 0.76 & 2.52 & 37.37 & BDL & 3.48 & 11.09 & 15.98 & 2.93 \\
\hline M2WSW & 23-Oct-13 & 12.45 & 0.89 & 2.88 & 52.62 & BDL & 2.49 & 11.98 & 16.12 & 2.60 \\
\hline M3ESW & $23-$ Oct-13 & 12.78 & 0.75 & 2.90 & 51.30 & $\mathrm{BDL}$ & 4.41 & 13.46 & 6.73 & 2.21 \\
\hline M3WSW & 23-Oct-13 & 13.36 & 0.71 & 2.98 & 47.76 & BDL & 4.98 & 12.11 & 8.25 & 2.08 \\
\hline M4ESW & 23-Oct-13 & 13.16 & 0.77 & 2.77 & 42.91 & BDL & 5.71 & 12.27 & 9.81 & 1.59 \\
\hline M4WSW & 23-Oct-13 & 12.88 & 0.88 & 2.75 & 41.90 & 0.01 & 5.47 & 12.41 & 11.48 & 1.58 \\
\hline M1E10S & 14-May-14 & 13.59 & 0.84 & 13.18 & 135.06 & 4.83 & 17.04 & 20.31 & 1.86 & 8.09 \\
\hline M1E12R & 14-Маy-14 & 15.70 & 0.07 & 11.80 & 121.18 & 0.03 & 16.68 & 25.05 & 1.91 & 9.46 \\
\hline M1E4 & 14-Мay-14 & 31.63 & 0.58 & 7.82 & 131.56 & 6.75 & 208.33 & 47.02 & 2.40 & 14.98 \\
\hline M1E5 & 14-May-14 & 35.89 & 2.70 & 15.72 & 194.71 & 10.25 & 77.44 & 34.32 & 0.01 & 0.47 \\
\hline M1W5 & 14-Мay-14 & 77.38 & 1.79 & 20.16 & 291.19 & 3.64 & 49.35 & 49.80 & -0.20 & 1.16 \\
\hline M1W8 & 14-Мay-14 & 42.09 & 3.04 & 12.92 & 193.14 & 3.65 & 32.97 & 33.81 & 0.55 & 5.31 \\
\hline M1W8 Deep & 14-May-14 & 62.38 & 3.18 & 14.43 & 217.92 & 1.93 & 45.47 & 40.10 & 0.31 & 1.22 \\
\hline M2E10S & 14-Мay-14 & 6.82 & 0.73 & 7.31 & 136.04 & 7.14 & 22.03 & 18.17 & 1.39 & 7.68 \\
\hline M2E12R & 14-May-14 & 17.44 & 0.18 & 7.57 & 122.05 & 0.01 & 15.78 & 21.76 & 1.00 & 8.17 \\
\hline M2E4 & 14-Маy-14 & 15.17 & 0.07 & 6.22 & 72.29 & 0.17 & 14.57 & 28.18 & 1.36 & 4.40 \\
\hline M2E5 & 14-Мay-14 & 50.38 & 2.27 & 15.02 & 149.47 & 4.57 & 55.20 & 83.46 & -0.57 & -3.02 \\
\hline M2W5 & 14-Мay-14 & 26.54 & 2.03 & 9.82 & 158.63 & 3.17 & 29.98 & 35.43 & 0.13 & -0.36 \\
\hline M2W9 & 14-May-14 & 29.20 & 0.22 & 14.53 & 136.79 & 0.51 & 24.62 & 54.18 & 0.64 & 3.06 \\
\hline M3E10S & 14-Маy-14 & 21.28 & 1.02 & 10.16 & 150.32 & 6.26 & 55.91 & 25.98 & 2.26 & 10.75 \\
\hline M3E12R & 14-Мay-14 & 17.97 & 0.40 & 7.94 & 91.07 & 0.00 & 13.59 & 39.74 & 0.93 & 4.76 \\
\hline M3E4 & 14-Маy-14 & 20.35 & 0.10 & 7.41 & 100.48 & 0.06 & 22.60 & 44.38 & 1.91 & 11.27 \\
\hline M3E5 & 14-Маy-14 & 114.48 & 5.21 & 28.36 & 322.83 & 14.55 & 64.65 & 108.33 & -0.75 & -1.82 \\
\hline
\end{tabular}




\begin{tabular}{|c|c|c|c|c|c|c|c|c|c|c|}
\hline Name Sample & $\begin{array}{c}\text { Date } \\
\text { Collection }\end{array}$ & $\begin{array}{c}\mathrm{Na}^{+} \\
(\mathbf{m g} / \mathrm{L})\end{array}$ & $\begin{array}{c}\mathbf{K}^{+} \\
(\mathbf{m g} / \mathbf{l})\end{array}$ & $\begin{array}{c}\mathrm{Mg}^{2+} \\
(\mathrm{mg} / \mathrm{L})\end{array}$ & $\begin{array}{c}\mathrm{Ca}^{2+} \\
(\mathbf{m g} / \mathbf{l})\end{array}$ & $\begin{array}{c}\mathrm{NH}_{4}{ }^{+} \\
(\mathrm{mg} / \mathrm{L})\end{array}$ & $\begin{array}{c}\text { TP } \\
(\mathrm{mg} / \mathrm{L})\end{array}$ & $\begin{array}{c}\text { TOC } \\
(\mathrm{mg} / \mathrm{L})\end{array}$ & $\delta^{18} \mathrm{O} \%$ & $\delta \mathrm{D} \%$ \\
\hline M3E8 Deep & 14-May-14 & 75.47 & 5.00 & 17.19 & 279.45 & 5.71 & 70.49 & 96.22 & 0.13 & -0.40 \\
\hline M3W5 & 14-May-14 & 43.60 & 6.40 & 10.50 & 152.29 & 3.54 & 36.38 & 29.44 & 0.99 & 4.78 \\
\hline M3W9 & 14-Мay-14 & 30.86 & 0.59 & 13.29 & 195.04 & 0.15 & 20.30 & 49.24 & 1.11 & 7.62 \\
\hline M4E10S & 14-Маy-14 & 13.62 & 1.04 & 4.96 & 104.41 & 4.84 & 16.59 & 14.16 & 1.79 & 12.27 \\
\hline M4E12R & 14-May-14 & 11.92 & 0.04 & 8.75 & 105.71 & 0.01 & 14.60 & 19.30 & 1.24 & 10.60 \\
\hline M4E4 & 14-Мау-14 & 36.02 & 0.14 & 8.54 & 100.00 & 1.72 & 25.99 & 42.02 & 1.88 & 12.62 \\
\hline M4E5 & 14-Мау-14 & 37.46 & 2.86 & 16.72 & 214.43 & 5.84 & 75.34 & 39.42 & -0.64 & 0.47 \\
\hline M4W5 & 14-Маy-14 & 53.38 & 5.17 & 15.52 & 227.40 & 3.57 & 26.34 & 54.78 & 0.09 & 1.76 \\
\hline M4W9 & 14-Маy-14 & 15.25 & 0.00 & 6.04 & 113.26 & 0.55 & 40.91 & 32.61 & 1.72 & 14.01 \\
\hline M1ESW & 14-Мау-14 & 23.79 & 2.73 & 4.79 & 52.04 & 0.03 & 17.11 & 17.46 & 21.19 & 3.34 \\
\hline M1WSW & 14-Мay-14 & 23.23 & 2.63 & 4.36 & 43.52 & 0.01 & 24.81 & 16.56 & 20.77 & 4.04 \\
\hline M2ESW & 14-Мау-14 & 26.48 & 3.51 & 6.29 & 87.07 & 0.10 & 21.57 & 19.19 & 19.85 & 3.69 \\
\hline M2WSW & 14-Маy-14 & 18.95 & 0.91 & 4.85 & 82.38 & 0.07 & 40.24 & 18.73 & 14.83 & 2.32 \\
\hline M3ESW & 14-Маy-14 & 21.18 & 2.55 & 4.79 & 56.68 & 0.04 & 12.21 & 14.43 & 16.62 & 3.27 \\
\hline M3WSW & 14-May-14 & 20.59 & 2.51 & 4.53 & 64.24 & 0.09 & 26.32 & 15.18 & 15.31 & 3.02 \\
\hline M4ESW & 14-Мау-14 & 21.93 & 2.56 & 4.49 & 55.33 & 0.02 & 11.71 & 15.42 & 19.95 & 3.25 \\
\hline M4WSW & 14-Маy-14 & 23.00 & 2.73 & 4.65 & 55.00 & 0.06 & 42.17 & 16.26 & 19.95 & 3.25 \\
\hline M1E10S & 15-Oct-14 & 14.07 & 1.31 & 13.40 & 142.39 & 6.18 & 15.34 & 19.19 & 2.20 & 13.56 \\
\hline M1E12R & 15-Oct-14 & 17.86 & 0.22 & 11.03 & 123.38 & 0.14 & 15.65 & 23.51 & 1.54 & 9.01 \\
\hline M1E4 & 15 -Oct-14 & 34.48 & 0.93 & 9.46 & 167.93 & 7.38 & 194.30 & 61.18 & -0.17 & -2.35 \\
\hline M1E5 & 15 -Oct-14 & 48.52 & 2.49 & 24.95 & 312.99 & 8.75 & 6.87 & 79.04 & -1.30 & -3.07 \\
\hline M1W5 & 15 -Oct-14 & 127.90 & 0.04 & 22.17 & 395.78 & 5.28 & 96.05 & 48.85 & -0.56 & 2.60 \\
\hline M1W5 Shallow & 15-Oct-14 & 75.62 & 1.68 & 18.61 & 284.26 & 0.44 & 39.80 & 98.72 & -0.82 & -2.62 \\
\hline M1W8 & 15-Oct-14 & 63.86 & 2.50 & 15.85 & 234.73 & 6.89 & 28.09 & 54.79 & -0.63 & 0.23 \\
\hline M1W8 Deep & 15-Oct-14 & 104.31 & 2.09 & 21.95 & 304.88 & 1.31 & 40.77 & 71.74 & 0.21 & 1.68 \\
\hline M2E10S & 15-Oct-14 & 11.39 & 1.01 & 6.17 & 133.68 & 8.19 & 17.27 & 15.78 & 2.06 & 12.25 \\
\hline M2E12R & 15-Oct-14 & 15.37 & 0.20 & 6.86 & 113.10 & 0.10 & 13.91 & 23.40 & 1.57 & 10.55 \\
\hline
\end{tabular}




\begin{tabular}{|c|c|c|c|c|c|c|c|c|c|c|}
\hline Name Sample & $\begin{array}{c}\text { Date } \\
\text { Collection }\end{array}$ & $\begin{array}{c}\mathrm{Na}^{+} \\
(\mathrm{mg} / \mathrm{L})\end{array}$ & $\begin{array}{c}\mathrm{K}^{+} \\
(\mathrm{mg} / \mathrm{l})\end{array}$ & $\begin{array}{c}\mathrm{Mg}^{2+} \\
(\mathrm{mg} / \mathrm{L})\end{array}$ & $\begin{array}{c}\mathrm{Ca}^{2+} \\
(\mathrm{mg} / \mathrm{l})\end{array}$ & $\begin{array}{c}\mathrm{NH}_{4}^{+} \\
(\mathrm{mg} / \mathrm{L})\end{array}$ & $\begin{array}{c}\mathbf{T P} \\
(\mathrm{mg} / \mathrm{L})\end{array}$ & $\begin{array}{c}\text { TOC } \\
(\mathrm{mg} / \mathrm{L})\end{array}$ & $\delta^{18} \mathrm{O} \%$ & $\delta D \%$ \\
\hline M2E4 & 15-Oct-14 & 12.04 & 0.23 & 4.28 & 95.10 & 0.12 & 16.34 & 16.67 & 0.17 & 2.00 \\
\hline M2E5 & 15-Oct-14 & 65.36 & 0.55 & 13.49 & 184.77 & 8.62 & 132.80 & 125.80 & -1.24 & -3.66 \\
\hline M2W5 & 15-Oct-14 & 31.62 & 1.58 & 12.54 & 229.66 & 1.11 & 16.92 & 52.15 & -1.86 & -4.33 \\
\hline M2W9 & 15-Oct-14 & 23.73 & 0.18 & 8.26 & 141.76 & 0.68 & 13.57 & 35.98 & 0.47 & 5.94 \\
\hline M3E10S & 15-Oct-14 & 19.41 & 1.01 & 10.58 & 146.52 & 5.62 & 5.74 & 24.04 & 2.26 & 11.49 \\
\hline M3E12R & $15-O c t-14$ & 17.22 & 0.30 & 8.01 & 87.60 & 0.21 & 6.92 & 37.36 & 1.23 & 10.28 \\
\hline M3E4 & 15-Oct-14 & 27.07 & 0.06 & 9.75 & 177.68 & 0.84 & 16.47 & 49.35 & 0.45 & 4.36 \\
\hline M3E5 & 15-Oct-14 & 172.08 & 2.71 & 39.21 & 437.45 & 3.16 & 234.19 & 179.70 & -1.65 & -4.54 \\
\hline M3E8 Deep & 15-Oct-14 & 124.60 & 1.95 & 30.22 & 413.91 & 3.44 & 101.24 & 154.70 & -0.25 & -0.12 \\
\hline M3W5 & 15-Oct-14 & 55.26 & 6.50 & 12.28 & 188.62 & 4.05 & 25.76 & 44.18 & 0.67 & 4.96 \\
\hline M3W9 & 15-Oct-14 & 25.12 & 0.62 & 10.06 & 191.67 & 0.94 & 27.07 & 31.86 & 1.15 & 6.64 \\
\hline M4E10S & 15 -Oct-14 & 15.20 & 1.17 & 5.07 & 116.61 & 5.05 & 18.37 & 14.39 & 2.23 & 13.27 \\
\hline M4E12R & 15-Oct-14 & 15.34 & 0.12 & 8.00 & 106.40 & 0.02 & 21.00 & 22.11 & 1.49 & 16.22 \\
\hline M4E4 & 15-Oct-14 & 22.26 & 0.64 & 6.75 & 144.83 & 1.89 & 23.60 & 27.84 & 1.08 & 2.83 \\
\hline M4E5 & 15-Oct-14 & 45.46 & 1.35 & 19.83 & 266.47 & 2.50 & 54.08 & 62.35 & -0.72 & -0.98 \\
\hline M4W5 & 15 -Oct-14 & 109.91 & 5.04 & 25.90 & 338.94 & 4.94 & 40.41 & 98.03 & -0.12 & 0.65 \\
\hline M4W9 & 15-Oct-14 & 24.33 & 0.26 & 7.49 & 131.81 & 3.12 & 54.80 & 47.16 & 1.49 & 7.26 \\
\hline M1ESW & 15 -Oct-14 & 23.79 & 2.73 & 4.79 & 52.04 & 0.11 & 6.87 & 11.75 & 4.95 & 1.24 \\
\hline M1WSW & 15-Oct-14 & 12.06 & 0.86 & 2.89 & 44.78 & 0.09 & 11.08 & 11.90 & 6.27 & 1.67 \\
\hline M2ESW & 15 -Oct-14 & 11.30 & 0.99 & 2.70 & 48.26 & 0.32 & 8.94 & 11.63 & 2.75 & 0.38 \\
\hline M2WSW & 15 -Oct-14 & 11.58 & 1.10 & 2.83 & 48.18 & 0.17 & 7.01 & 12.76 & 3.32 & 0.66 \\
\hline M3ESW & 15-Oct-14 & 10.60 & 0.48 & 2.92 & 50.75 & 0.03 & 7.47 & 12.00 & 4.09 & 1.58 \\
\hline M3WSW & 15 -Oct-14 & 11.48 & 0.86 & 3.03 & 54.46 & 3.62 & 6.25 & 12.40 & 7.86 & 1.37 \\
\hline M4ESW & 15 -Oct-14 & 11.85 & 1.10 & 2.94 & 49.27 & 0.16 & 10.16 & 11.25 & 3.59 & 0.30 \\
\hline M4WSW & 15-Oct-14 & 11.69 & 1.13 & 2.90 & 54.39 & 0.04 & 11.23 & 11.31 & 6.56 & 1.27 \\
\hline M1E10S & 22-Мay-15 & 16.71 & 1.85 & 13.16 & 152.60 & 0.17 & 7.93 & 20.42 & 1.89 & 11.71 \\
\hline M1E12R & 22-May-15 & 18.91 & 0.44 & 10.11 & 106.64 & 0.07 & 6.50 & 27.20 & 2.09 & 14.61 \\
\hline
\end{tabular}




\begin{tabular}{|c|c|c|c|c|c|c|c|c|c|c|}
\hline Name Sample & $\begin{array}{c}\text { Date } \\
\text { Collection }\end{array}$ & $\begin{array}{c}\mathrm{Na}^{+} \\
(\mathbf{m g} / \mathrm{L})\end{array}$ & $\begin{array}{c}\mathbf{K}^{+} \\
(\mathbf{m g} / \mathbf{l})\end{array}$ & $\begin{array}{c}\mathrm{Mg}^{2+} \\
(\mathrm{mg} / \mathrm{L})\end{array}$ & $\begin{array}{c}\mathrm{Ca}^{2+} \\
(\mathbf{m g} / \mathbf{l})\end{array}$ & $\begin{array}{c}\mathrm{NH}_{4}{ }^{+} \\
(\mathrm{mg} / \mathrm{L})\end{array}$ & $\begin{array}{c}\mathbf{T P} \\
(\mathrm{mg} / \mathrm{L})\end{array}$ & $\begin{array}{c}\text { TOC } \\
(\mathrm{mg} / \mathrm{L})\end{array}$ & $\delta^{18} \mathrm{O} \%$ & $\delta \mathrm{D} \%$ \\
\hline M1E4 & 22-May-15 & 38.81 & 1.63 & 11.10 & 174.47 & 0.33 & 43.04 & 46.05 & 0.36 & 1.81 \\
\hline M1E5 & 22-May-15 & 40.66 & 3.68 & 14.12 & 176.25 & 0.34 & 9.57 & 30.60 & 0.22 & 2.97 \\
\hline M1W5 & 22-May-15 & 63.90 & 1.92 & 17.11 & 257.43 & 0.34 & 14.56 & 43.89 & -0.11 & 3.37 \\
\hline M1W5 Shallow & 22-Мау-15 & 88.91 & 0.52 & 18.04 & 302.73 & 0.07 & 13.99 & 56.81 & -0.15 & 1.00 \\
\hline M1W8 & 22-May-15 & 37.48 & 3.10 & 12.38 & 191.41 & 0.28 & 6.69 & 28.77 & 0.96 & 6.62 \\
\hline M1W8 Deep & 22-May-15 & 61.37 & 3.16 & 14.76 & 220.82 & 0.19 & 11.22 & 38.78 & 0.04 & 2.62 \\
\hline M2E10S & 22-May-15 & 10.93 & 1.56 & 7.17 & 144.53 & 0.29 & 6.40 & 18.15 & 1.83 & 12.91 \\
\hline M2E12R & 22-Маy-15 & 14.90 & 0.70 & 6.52 & 114.53 & 0.05 & 10.25 & 23.58 & 1.31 & 9.62 \\
\hline M2E4 & 22-Маy-15 & 23.12 & 0.62 & 7.58 & 85.80 & 0.02 & 11.72 & 35.42 & 1.61 & 9.31 \\
\hline M2E5 & 22-Мay-15 & 53.92 & 2.65 & 15.49 & 157.65 & 0.45 & 16.73 & 69.97 & -0.34 & 0.87 \\
\hline M2W5 & 22-Мay-15 & 30.08 & 2.20 & 10.90 & 157.12 & 0.33 & 6.81 & 30.26 & 0.04 & 0.84 \\
\hline M2W9 & 22-Маy-15 & 23.97 & 0.66 & 12.36 & 122.91 & 0.03 & 7.84 & 42.02 & 0.81 & 4.48 \\
\hline M3E10S & 22-Мay-15 & 19.78 & 0.92 & 9.72 & 156.35 & 0.54 & 5.57 & 26.93 & 1.60 & 10.04 \\
\hline M3E12R & 22-Мау-15 & 17.45 & 0.52 & 7.81 & 89.74 & 0.10 & 4.55 & 34.86 & 1.15 & 7.74 \\
\hline M3E4 & 22-Мау-15 & 22.04 & BDL. & 7.04 & 86.76 & 0.15 & 13.09 & 40.05 & 1.66 & 11.52 \\
\hline M3E5 & 22-Мay-15 & 73.58 & 4.88 & 14.33 & 185.15 & 0.47 & 36.79 & 73.08 & 0.21 & 0.32 \\
\hline M3E8 Deep & 22-Маy-15 & 78.96 & 4.35 & 16.91 & 277.90 & 0.16 & 12.92 & 88.60 & 0.42 & 4.81 \\
\hline M3W5 & 22-Маy-15 & 45.25 & 6.34 & 10.66 & 158.41 & 0.36 & 6.99 & 27.75 & 1.14 & 8.59 \\
\hline M3W9 & 22-Мау-15 & 28.35 & 0.97 & 12.43 & 157.05 & 0.04 & 9.73 & 45.36 & 0.59 & 5.41 \\
\hline M4E10S & 22-Маy-15 & 14.24 & 1.99 & 5.10 & 114.79 & 0.02 & 5.21 & 12.15 & 1.59 & 6.96 \\
\hline M4E12R & 22-Мay-15 & 17.10 & 0.35 & 7.09 & 100.37 & 0.45 & 7.14 & 23.76 & 1.07 & 7.64 \\
\hline M4E4 & 22-Мау-15 & 29.92 & 0.28 & 9.56 & 90.03 & 0.05 & 8.80 & 37.64 & 1.65 & 14.91 \\
\hline M4E5 & 22-May-15 & 36.14 & 3.61 & 16.81 & 211.65 & 0.29 & 11.00 & 36.78 & -0.45 & 1.21 \\
\hline M4W5 & 22-Мау-15 & 48.50 & 4.88 & 14.18 & 209.90 & 0.03 & 9.84 & 41.60 & 0.48 & 4.00 \\
\hline M4W9 & 22-Мау-15 & 17.89 & 0.03 & 6.61 & 138.65 & 0.33 & 9.40 & 28.94 & 2.14 & 15.78 \\
\hline M1ESW & 22-Мay-15 & 24.57 & 1.93 & 5.24 & 85.93 & 0.05 & 5.12 & 18.86 & 18.31 & 3.70 \\
\hline M1WSW & 22-Мау-15 & 24.57 & 1.93 & 5.24 & 85.93 & 0.05 & 5.12 & 18.86 & 18.31 & 3.70 \\
\hline
\end{tabular}




\begin{tabular}{|c|c|c|c|c|c|c|c|c|c|c|}
\hline Name Sample & $\begin{array}{c}\text { Date } \\
\text { Collection }\end{array}$ & $\begin{array}{c}\mathrm{Na}^{+} \\
(\mathbf{m g} / \mathrm{L})\end{array}$ & $\begin{array}{c}\mathbf{K}^{+} \\
(\mathbf{m g} / \mathbf{l})\end{array}$ & $\begin{array}{c}\mathrm{Mg}^{2+} \\
(\mathrm{mg} / \mathrm{L})\end{array}$ & $\begin{array}{c}\mathrm{Ca}^{2+} \\
(\mathbf{m g} / \mathbf{l})\end{array}$ & $\begin{array}{c}\mathrm{NH}_{4}{ }^{+} \\
(\mathrm{mg} / \mathrm{L})\end{array}$ & $\begin{array}{c}\mathbf{T P} \\
(\mathrm{mg} / \mathrm{L})\end{array}$ & $\begin{array}{c}\text { TOC } \\
(\mathrm{mg} / \mathrm{L})\end{array}$ & $\delta^{18} \mathrm{O} \%$ & $\delta \mathrm{D} \%$ \\
\hline M2ESW & 22-May-15 & 30.03 & 4.90 & 6.11 & 75.86 & 0.07 & 38.99 & 25.32 & 22.85 & 4.34 \\
\hline M2WSW & 22-May-15 & 28.25 & 4.52 & 6.52 & 66.39 & 0.01 & 4.25 & 20.71 & 22.41 & 4.28 \\
\hline M3ESW & 22-May-15 & 23.56 & 3.59 & 5.54 & 79.90 & 0.08 & 6.57 & 18.40 & 19.83 & 3.53 \\
\hline M3WSW & 22-Мау-15 & 23.56 & 3.59 & 5.54 & 79.90 & 0.08 & 6.57 & 18.40 & 19.83 & 3.53 \\
\hline M4ESW & 22-May-15 & 28.61 & 4.03 & 5.89 & 75.87 & 0.08 & 36.77 & 20.13 & 22.46 & 5.24 \\
\hline M4WSW & 22-May-15 & 28.61 & 4.03 & 5.89 & 75.87 & 0.08 & 36.77 & 20.13 & 22.46 & 5.24 \\
\hline M1E10S & 20-Oct-15 & 17.18 & 1.68 & 11.63 & 142.22 & 4.97 & 15.20 & 20.85 & 1.76 & 12.45 \\
\hline M1E12R & 20-Oct-15 & 19.52 & 0.25 & 9.44 & 100.64 & 0.36 & 18.50 & 28.18 & 1.64 & 12.60 \\
\hline M1E4 & 20-Oct-15 & 45.47 & 0.53 & 12.67 & 207.62 & 3.23 & 50.53 & 62.16 & -0.76 & -1.68 \\
\hline M1E5 & 20-Oct-15 & 73.93 & 0.60 & 32.23 & 410.07 & 1.70 & 42.95 & 69.96 & -1.38 & -2.03 \\
\hline M1W5 & 20-Oct-15 & 56.39 & 1.66 & 15.07 & 230.57 & 2.85 & 32.76 & 37.20 & 0.55 & 3.98 \\
\hline M1W5 Shallow & 20-Oct-15 & 180.90 & 0.20 & 25.77 & 460.92 & 0.16 & 38.29 & 90.36 & -1.35 & -5.87 \\
\hline M1W8 & 20-Oct-15 & 46.06 & 2.80 & 13.84 & 213.41 & 4.01 & 23.25 & 34.24 & -0.28 & 3.57 \\
\hline M1W8 Deep & 20-Oct-15 & 80.49 & 2.22 & 18.28 & 276.54 & 0.72 & 28.15 & 51.76 & 0.22 & 6.27 \\
\hline M2E10S & 20-Oct-15 & 14.87 & 1.98 & 7.50 & 143.33 & 7.60 & 14.63 & 18.74 & 2.12 & 14.50 \\
\hline M2E12R & 20-Oct-15 & 15.78 & 0.36 & 6.72 & 110.20 & 0.04 & 9.91 & 24.47 & 1.09 & 8.36 \\
\hline M2E4 & 20-Oct-15 & 19.72 & 0.93 & 5.52 & 108.50 & 0.67 & 13.16 & 23.66 & 0.27 & 3.81 \\
\hline M2E5 & $20-$ Oct-15 & 69.65 & 0.98 & 16.67 & 200.34 & 4.21 & 51.23 & 94.50 & -1.06 & -2.89 \\
\hline M2W5 & 20-Oct-15 & 46.42 & 0.83 & 13.35 & 248.42 & 0.34 & 17.31 & 41.24 & -1.26 & -3.95 \\
\hline M2W9 & 20-Oct-15 & 30.32 & 1.04 & 10.65 & 149.26 & 1.68 & 13.23 & 36.20 & 0.73 & 4.98 \\
\hline M3E10S & 20-Oct-15 & 15.91 & 0.91 & 11.45 & 156.63 & 5.80 & 10.75 & 24.38 & 2.06 & 10.74 \\
\hline M3E12R & 20-Oct-15 & 15.82 & 0.26 & 7.61 & 86.95 & 0.06 & 5.56 & 32.51 & 0.92 & 7.15 \\
\hline M3E4 & $20-$ Oct- 15 & 31.96 & 0.28 & 8.92 & 144.25 & 1.37 & 21.75 & 53.48 & 0.50 & 6.44 \\
\hline M3E5 & $20-$ Oct-15 & 163.15 & 1.70 & 36.15 & 418.34 & 3.20 & 53.32 & 146.75 & -0.46 & 2.02 \\
\hline M3E8 Deep & 20-Oct-15 & 147.88 & 1.71 & 34.66 & 494.28 & 2.39 & 26.29 & 154.20 & -0.43 & 0.77 \\
\hline M3W5 & $20-O c t-15$ & 59.28 & 5.52 & 12.55 & 192.45 & 1.97 & 15.76 & 32.48 & 1.04 & 8.62 \\
\hline M3W9 & 20-Oct-15 & 26.89 & 1.37 & 10.40 & 202.11 & 1.29 & 14.02 & 37.09 & -0.22 & 0.92 \\
\hline
\end{tabular}




$\begin{array}{ccccccccccc}\text { Name Sample } & \begin{array}{c}\text { Date } \\ \text { Collection }\end{array} & \begin{array}{c}\mathbf{N a}^{+} \\ (\mathbf{m g} / \mathbf{L})\end{array} & \begin{array}{c}\mathbf{K}^{+} \\ (\mathbf{m g} / \mathbf{l})\end{array} & \begin{array}{c}\mathbf{M g}^{2+} \\ (\mathbf{m g} / \mathbf{L})\end{array} & \begin{array}{c}\mathbf{C a}^{\mathbf{2 +}} \\ (\mathbf{m g} / \mathbf{l})\end{array} & \begin{array}{c}\mathbf{N H}_{4}^{+} \\ (\mathbf{m g} / \mathbf{L})\end{array} & \begin{array}{c}\mathbf{T P} \\ (\mathbf{m g} / \mathbf{L})\end{array} & \begin{array}{c}\mathbf{T O C} \\ (\mathbf{m g} / \mathbf{L})\end{array} & \boldsymbol{\delta}^{\mathbf{1 8}} \mathbf{O} \text { \%o } & \mathbf{\delta D ~ \% o} \\ \text { M4E10S } & 20-\text { Oct-15 } & 17.57 & 2.10 & 5.62 & 119.56 & 0.02 & 5.41 & 14.87 & 2.31 & 16.38 \\ \text { M4E12R } & \text { 20-Oct-15 } & 17.31 & 0.16 & 6.69 & 81.40 & 7.53 & 8.82 & 27.53 & 1.60 & 9.87 \\ \text { M4E4 } & \text { 20-Oct-15 } & 31.21 & 0.32 & 8.33 & 152.18 & 1.55 & 18.34 & 38.06 & 0.59 & 4.40 \\ \text { M4E5 } & \text { 20-Oct-15 } & 54.55 & 1.69 & 22.39 & 311.87 & 3.33 & 16.54 & 42.95 & -0.80 & -0.99 \\ \text { M4W5 } & \text { 20-Oct-15 } & 41.12 & 4.95 & 12.63 & 199.68 & 3.62 & 10.88 & 33.59 & 0.81 & 4.67 \\ \text { M4W9 } & \text { 20-Oct-15 } & 22.93 & 1.08 & 5.57 & 102.63 & 0.97 & 32.54 & 28.45 & 1.08 & 6.61 \\ \text { M1ESW } & \text { 20-Oct-15 } & 17.55 & 2.04 & 3.93 & 57.98 & 0.03 & 28.55 & 18.11 & 6.16 & 1.22 \\ \text { M1WSW } & \text { 20-Oct-15 } & 17.56 & 2.47 & 4.12 & 63.74 & 0.04 & 5.39 & 17.29 & 10.14 & 1.11 \\ \text { M2ESW } & \text { 20-Oct-15 } & 15.79 & 2.53 & 3.53 & 48.80 & 0.08 & 7.58 & 16.58 & 7.59 & 0.92 \\ \text { M2WSW } & \text { 20-Oct-15 } & 17.61 & 2.34 & 3.91 & 51.91 & 0.00 & 5.82 & 17.16 & 8.64 & 1.30 \\ \text { M3ESW } & \text { 20-Oct-15 } & 15.90 & 2.30 & 3.85 & 56.26 & 0.00 & 6.19 & 16.38 & 7.70 & 1.42 \\ \text { M3WSW } & \text { 20-Oct-15 } & 16.82 & 2.08 & 3.96 & 58.74 & 0.03 & 4.19 & 17.31 & 7.35 & 1.89 \\ \text { M4ESW } & \text { 20-Oct-15 } & 18.24 & 2.20 & 3.84 & 51.48 & 0.03 & 5.45 & 15.57 & 10.59 & 1.87 \\ \text { M4WSW } & \text { 20-Oct-15 } & 17.95 & 2.00 & 4.03 & 59.01 & 0.14 & 10.41 & 15.45 & 6.88 & 0.92\end{array}$

4, 8, 9 = Edge; 5 = Center; $\mathrm{S}=$ Slough $; \mathrm{R}=$ Ridge; $\mathrm{SW}=$ Surface Water $; \mathrm{BDL}=$ Below Detection Limit 


\section{APPENDIX C}

Hydrogeochemical Parameters 


\begin{tabular}{|c|c|c|c|c|c|c|}
\hline Name Sample & $\begin{array}{c}\text { Date } \\
\text { Collection }\end{array}$ & IS & SI $\mathbf{I}_{\text {aragonite }}$ & $\mathbf{S} \mathbf{I}_{\text {calcite }}$ & $\mathbf{S I}_{\text {dolomite }}$ & $\log \left(p \mathrm{CO}_{2}\right)$ \\
\hline M1E10S & $18-O c t-13$ & 0.01 & 0.19 & 0.33 & -0.03 & -1.29 \\
\hline M1E12R & 18-Oct-13 & 0.01 & 0.00 & 0.15 & -0.36 & -1.14 \\
\hline M1E4 & 18-Oct-13 & 0.02 & 0.10 & 0.25 & -0.37 & -0.96 \\
\hline M1E5 & 18-Oct-13 & 0.02 & 0.87 & 1.01 & 1.28 & -1.24 \\
\hline M1W5 & 18-Oct-13 & 0.03 & 0.17 & 0.32 & -0.16 & -0.55 \\
\hline M1W5 Shallow & 18-Oct-13 & 0.03 & 0.45 & 0.59 & 0.32 & -0.61 \\
\hline M1W8 & 18-Oct-13 & 0.02 & 0.00 & 0.14 & -0.52 & -0.66 \\
\hline M1W8 Deep & 18-Oct-13 & 0.02 & -0.01 & 0.14 & -0.54 & -0.70 \\
\hline M2E10S & 18-Oct-13 & 0.01 & -0.09 & 0.05 & -0.83 & -1.07 \\
\hline M2E12R & 18-Oct-13 & 0.01 & -0.36 & -0.22 & -1.24 & -0.98 \\
\hline M2E4 & 18-Oct-13 & 0.01 & -0.12 & 0.02 & -0.97 & -1.34 \\
\hline M2E5 & 18-Oct-13 & 0.01 & -0.03 & 0.11 & -0.60 & -1.09 \\
\hline M2W5 & 18-Oct-13 & 0.02 & 0.08 & 0.22 & -0.44 & -0.87 \\
\hline M2W9 & 18-Oct-13 & 0.01 & -0.28 & -0.14 & -1.14 & -0.72 \\
\hline M3E10S & 18-Oct-13 & 0.01 & 0.10 & 0.24 & -0.32 & -1.11 \\
\hline M3E12R & 18-Oct-13 & 0.01 & -0.21 & -0.07 & -0.81 & -1.45 \\
\hline M3E4 & 18-Oct-13 & 0.01 & -0.17 & -0.03 & -0.90 & -0.80 \\
\hline M3E5 & 18-Oct-13 & 0.04 & 0.71 & 0.86 & 0.96 & -0.58 \\
\hline M3E8 Deep & 18-Oct-13 & 0.03 & 1.04 & 1.19 & 1.59 & -1.13 \\
\hline M3W5 & 18-Oct-13 & 0.02 & -0.16 & -0.02 & -0.83 & -0.70 \\
\hline M3W9 & 18-Oct-13 & 0.02 & -0.05 & 0.09 & -0.73 & -0.76 \\
\hline M4E10S & 18-Oct-13 & 0.01 & 0.26 & 0.40 & -0.06 & -1.57 \\
\hline M4E12R & 18-Oct-13 & 0.01 & -0.12 & 0.02 & -0.60 & -1.25 \\
\hline M4E4 & 18-Oct-13 & 0.01 & 0.40 & 0.54 & 0.19 & -1.50 \\
\hline M4E5 & 18-Oct-13 & 0.02 & 0.57 & 0.72 & 0.69 & -1.11 \\
\hline
\end{tabular}




\begin{tabular}{|c|c|c|c|c|c|c|}
\hline Name Sample & $\begin{array}{c}\text { Date } \\
\text { Collection }\end{array}$ & IS & $\mathbf{S I}_{\text {aragonite }}$ & SI calcite & $\mathbf{S I}_{\text {dolomite }}$ & $\log \left(p \mathrm{CO}_{2}\right)$ \\
\hline M4W5 & 18-Oct-13 & 0.03 & 0.23 & 0.38 & -0.01 & -0.50 \\
\hline M4W9 & 18-Oct-13 & 0.01 & -0.44 & -0.30 & -1.45 & -0.80 \\
\hline M1ESW & 18-Oct-13 & 0.01 & 0.23 & 0.37 & -0.17 & -2.40 \\
\hline M1WSW & 18-Oct-13 & 0.01 & 0.14 & 0.28 & -0.33 & -2.26 \\
\hline M2ESW & 18-Oct-13 & 0.00 & -0.36 & -0.22 & -1.23 & -2.34 \\
\hline M2WSW & 18-Oct-13 & 0.00 & -0.03 & 0.11 & -0.66 & -2.27 \\
\hline M3ESW & 18-Oct-13 & 0.00 & -0.19 & -0.05 & -0.98 & -1.98 \\
\hline M3WSW & $18-O c t-13$ & 0.00 & -0.15 & -0.01 & -0.85 & -2.26 \\
\hline M4ESW & 18-Oct-13 & 0.00 & -0.13 & 0.01 & -0.81 & -2.31 \\
\hline M4WSW & 18-Oct-13 & 0.00 & -0.25 & -0.11 & -1.04 & -2.38 \\
\hline M1E10S & 14-May-14 & 0.01 & -0.10 & 0.05 & -0.57 & -1.05 \\
\hline M1E12R & 14-Мау-14 & 0.01 & -0.39 & -0.25 & -1.16 & -0.87 \\
\hline M1E4 & 14-Мау-14 & 0.01 & -0.18 & -0.04 & -0.96 & -1.09 \\
\hline M1E5 & 14-May-14 & 0.02 & 0.01 & 0.15 & -0.44 & -0.79 \\
\hline M1W5 & 14-Мay-14 & 0.03 & 0.29 & 0.44 & 0.06 & -0.75 \\
\hline M1W8 & 14-May-14 & 0.02 & -0.06 & 0.08 & -0.68 & -0.81 \\
\hline M1W8 Deep & 14-May-14 & 0.02 & -0.01 & 0.14 & -0.57 & -0.78 \\
\hline M2E10S & 14-Мay-14 & 0.01 & -0.09 & 0.06 & -0.81 & -1.09 \\
\hline M2E12R & 14-Мау-14 & 0.01 & -0.43 & -0.29 & -1.42 & -0.89 \\
\hline M2E4 & 14-Мау-14 & 0.01 & -1.09 & -0.95 & -2.62 & -0.89 \\
\hline M2E5 & 14-May-14 & 0.01 & -0.55 & -0.41 & -1.47 & -0.65 \\
\hline M2W5 & 14-May-14 & 0.01 & -0.25 & -0.10 & -1.08 & -0.78 \\
\hline M2W9 & 14-May-14 & 0.01 & -0.42 & -0.28 & -1.18 & -0.76 \\
\hline M3E10S & 14-May-14 & 0.01 & 0.27 & 0.41 & 0.01 & -1.32 \\
\hline M3E12R & 14-May-14 & 0.01 & -0.71 & -0.56 & -1.84 & -1.00 \\
\hline M3E4 & 14-Мау-14 & 0.01 & -0.66 & -0.52 & -1.82 & -0.99 \\
\hline M3E5 & 14-May-14 & 0.03 & 0.52 & 0.66 & 0.63 & -0.81 \\
\hline
\end{tabular}




\begin{tabular}{|c|c|c|c|c|c|c|}
\hline Name Sample & $\begin{array}{c}\text { Date } \\
\text { Collection }\end{array}$ & IS & SI $\mathbf{I}_{\text {aragonite }}$ & $\mathbf{S I} \mathbf{I}_{\text {calcite }}$ & $\mathbf{S I}_{\text {dolomite }}$ & $\log \left(p \mathrm{CO}_{2}\right)$ \\
\hline M3E8 Deep & 14-May-14 & 0.02 & 0.68 & 0.82 & 0.79 & -1.18 \\
\hline M3W5 & 14-May-14 & 0.01 & -0.19 & -0.05 & -0.92 & -0.86 \\
\hline M3W9 & 14-May-14 & 0.02 & -0.03 & 0.12 & -0.58 & -0.94 \\
\hline M4E10S & 14-May-14 & 0.01 & -0.23 & -0.09 & -1.15 & -1.28 \\
\hline M4E12R & 14-May-14 & 0.01 & -0.69 & -0.54 & -1.82 & -0.84 \\
\hline M4E4 & 14-May-14 & 0.01 & -0.73 & -0.59 & -1.90 & -1.05 \\
\hline M4E5 & 14-May-14 & 0.02 & 0.19 & 0.33 & -0.10 & -0.88 \\
\hline M4W5 & 14-May-14 & 0.02 & 0.07 & 0.21 & -0.39 & -0.70 \\
\hline M4W9 & 14-May-14 & 0.01 & -0.49 & -0.34 & -1.61 & -0.99 \\
\hline M1ESW & 14-May-14 & 0.01 & 0.50 & 0.64 & 0.62 & -2.80 \\
\hline M1WSW & 14-May-14 & 0.00 & 0.37 & 0.51 & 0.42 & -2.88 \\
\hline M2ESW & 14-May-14 & 0.01 & -0.18 & -0.03 & -0.87 & -1.59 \\
\hline M2WSW & 14-May-14 & 0.01 & -0.01 & 0.13 & -0.61 & -1.81 \\
\hline M3ESW & 14-May-14 & 0.01 & 0.00 & 0.14 & -0.43 & -2.21 \\
\hline M3WSW & 14-May-14 & 0.01 & 0.14 & 0.28 & -0.22 & -2.19 \\
\hline M4ESW & 14-May-14 & 0.01 & 0.04 & 0.18 & -0.35 & -2.23 \\
\hline M4WSW & 14-May-14 & 0.01 & 0.15 & 0.29 & -0.08 & -2.30 \\
\hline M1E10S & $15-O c t-14$ & 0.01 & -0.16 & -0.02 & -0.69 & -0.92 \\
\hline M1E12R & 15-Oct-14 & 0.01 & -0.35 & -0.21 & -1.09 & -0.88 \\
\hline M1E4 & 15-Oct-14 & 0.01 & -0.14 & 0.00 & -0.87 & -0.81 \\
\hline M1E5 & 15-Oct-14 & 0.03 & 0.40 & 0.54 & 0.35 & -0.68 \\
\hline M1W5 & 15-Oct-14 & 0.03 & 0.33 & 0.48 & 0.13 & -0.79 \\
\hline M1W5 Shallow & 15-Oct-14 & 0.04 & 0.75 & 0.90 & 0.91 & -0.86 \\
\hline M1W8 & 15-Oct-14 & 0.02 & 0.09 & 0.23 & -0.34 & -0.75 \\
\hline M1W8 Deep & 15-Oct-14 & 0.03 & 0.40 & 0.54 & 0.30 & -0.79 \\
\hline M2E10S & 15-Oct-14 & 0.01 & -0.06 & 0.09 & -0.79 & -1.09 \\
\hline M2E12R & 15-Oct-14 & 0.01 & -0.37 & -0.23 & -1.29 & -1.03 \\
\hline
\end{tabular}




\begin{tabular}{|c|c|c|c|c|c|c|}
\hline Name Sample & $\begin{array}{c}\text { Date } \\
\text { Collection }\end{array}$ & IS & SI $\mathbf{I}_{\text {aragonite }}$ & SI calcite & SI $\mathbf{I}_{\text {dolomite }}$ & $\log \left(p \mathrm{CO}_{2}\right)$ \\
\hline M2E4 & 15-Oct-14 & 0.01 & -0.46 & -0.32 & -1.62 & -1.14 \\
\hline M2E5 & 15-Oct-14 & 0.02 & -0.11 & 0.03 & -0.71 & -0.84 \\
\hline M2W5 & 15-Oct-14 & 0.02 & 0.31 & 0.45 & 0.01 & -0.97 \\
\hline M2W9 & 15-Oct-14 & 0.01 & -0.21 & -0.07 & -0.99 & -0.93 \\
\hline M3E10S & $15-O c t-14$ & 0.01 & 0.25 & 0.39 & 0.01 & -1.27 \\
\hline M3E12R & 15-Oct-14 & 0.01 & -0.63 & -0.49 & -1.64 & -1.07 \\
\hline M3E4 & $15-O c t-14$ & 0.01 & -0.11 & 0.03 & -0.83 & -0.83 \\
\hline M3E5 & 15-Oct-14 & 0.04 & 0.84 & 0.98 & 1.28 & -0.74 \\
\hline M3E8 Deep & 15-Oct-14 & 0.04 & 0.98 & 1.13 & 1.48 & -1.10 \\
\hline M3W5 & 15-Oct-14 & 0.02 & 0.02 & 0.16 & -0.50 & -0.88 \\
\hline M3W9 & 15-Oct-14 & 0.02 & 0.08 & 0.22 & -0.45 & -0.88 \\
\hline M4E10S & $15-O c t-14$ & 0.01 & -0.15 & 0.00 & -0.99 & -1.20 \\
\hline M4E12R & 15-Oct-14 & 0.01 & -0.42 & -0.27 & -1.30 & -1.05 \\
\hline M4E4 & 15-Oct-14 & 0.01 & -0.07 & 0.08 & -0.81 & -1.07 \\
\hline M4E5 & 15-Oct-14 & 0.02 & 0.49 & 0.63 & 0.49 & -0.98 \\
\hline M4W5 & 15-Oct-14 & 0.03 & 0.55 & 0.70 & 0.64 & -0.80 \\
\hline M4W9 & 15-Oct-14 & 0.01 & -0.32 & -0.17 & -1.22 & -0.90 \\
\hline M1ESW & 15-Oct-14 & 0.00 & -0.64 & -0.50 & -1.84 & -1.88 \\
\hline M1WSW & 15-Oct-14 & 0.00 & -0.50 & -0.36 & -1.53 & -1.97 \\
\hline M2ESW & 15-Oct-14 & 0.00 & -0.65 & -0.51 & -1.87 & -1.67 \\
\hline M2WSW & 15-Oct-14 & 0.00 & -0.55 & -0.41 & -1.66 & -1.83 \\
\hline M3ESW & 15-Oct-14 & 0.00 & -0.83 & -0.68 & -2.25 & -1.53 \\
\hline M3WSW & 15-Oct-14 & 0.00 & -0.60 & -0.46 & -1.79 & -1.64 \\
\hline M4ESW & 15-Oct-14 & 0.00 & -0.78 & -0.64 & -2.14 & -1.59 \\
\hline M4WSW & 15-Oct-14 & 0.00 & -0.52 & -0.38 & -1.66 & -1.73 \\
\hline M1E10S & 22-Мay-15 & 0.01 & -0.06 & 0.08 & -0.53 & -0.95 \\
\hline M1E12R & 22-Мay-15 & 0.01 & -0.08 & 0.07 & -0.53 & -1.34 \\
\hline
\end{tabular}




$\begin{array}{ccccccc}\text { Name Sample } & \begin{array}{c}\text { Date } \\ \text { Collection }\end{array} & \mathbf{I S} & \mathbf{S I}_{\text {aragonite }} & \mathbf{S I}_{\text {calcite }} & \mathbf{S I}_{\text {dolomite }} & \log \left(\mathbf{p} \mathbf{C O}_{2}\right) \\ \text { M1E4 } & \text { 22-May-15 } & 0.02 & -0.16 & -0.02 & -0.89 & -0.72 \\ \text { M1E5 } & \text { 22-May-15 } & 0.02 & 0.38 & 0.53 & 0.31 & -1.29 \\ \text { M1W5 } & \text { 22-May-15 } & 0.02 & 0.14 & 0.28 & -0.25 & -0.71 \\ \text { M1W5 Shallow } & \text { 22-May-15 } & 0.03 & 1.09 & 1.23 & 1.59 & -1.53 \\ \text { M1W8 } & \text { 22-May-15 } & 0.02 & 0.21 & 0.35 & -0.14 & -1.10 \\ \text { M1W8 Deep } & \text { 22-May-15 } & 0.02 & 0.05 & 0.20 & -0.44 & -0.82 \\ \text { M2E10S } & \text { 22-May-15 } & 0.01 & -0.19 & -0.04 & -1.03 & -0.90 \\ \text { M2E12R } & \text { 22-May-15 } & 0.01 & -0.53 & -0.39 & -1.67 & -0.92 \\ \text { M2E4 } & \text { 22-May-15 } & 0.01 & -0.88 & -0.74 & -2.18 & -0.77 \\ \text { M2E5 } & \text { 22-May-15 } & 0.02 & -0.52 & -0.37 & -1.41 & -0.65 \\ \text { M2W5 } & \text { 22-May-15 } & 0.01 & 0.24 & 0.38 & -0.06 & -1.26 \\ \text { M2W9 } & \text { 22-May-15 } & 0.01 & -0.59 & -0.45 & -1.56 & -0.77 \\ \text { M3E10S } & \text { 22-May-15 } & 0.01 & 1.07 & 1.22 & 1.59 & -2.09 \\ \text { M3E12R } & \text { 22-May-15 } & 0.01 & -0.43 & -0.28 & -1.28 & -1.24 \\ \text { M3E4 } & \text { 22-May-15 } & 0.01 & -0.95 & -0.80 & -2.33 & -0.86 \\ \text { M3E5 } & \text { 22-May-15 } & 0.02 & 1.12 & 1.26 & 1.71 & -2.17 \\ \text { M3E8 Deep } & \text { 22-May-15 } & 0.02 & 1.30 & 1.44 & 2.02 & -1.81 \\ \text { M3W5 } & \text { 22-May-15 } & 0.01 & -0.18 & -0.04 & -0.89 & -0.86 \\ \text { M3W9 } & \text { 22-May-15 } & 0.01 & -0.05 & 0.09 & -0.56 & -0.96 \\ \text { M4E10S } & \text { 22-May-15 } & 0.01 & -0.29 & -0.15 & -1.29 & -1.09 \\ \text { M4E12R } & \text { 22-May-15 } & 0.01 & -0.72 & -0.58 & -1.95 & -0.85 \\ \text { M4E4 } & \text { 22-May-15 } & 0.01 & -0.89 & -0.75 & -2.11 & -0.83 \\ \text { M4E5 } & \text { 22-May-15 } & 0.02 & 0.59 & 0.73 & 0.71 & -1.32 \\ \text { M4W5 } & \text { 22-May-15 } & 0.02 & -0.03 & 0.12 & -0.59 & -0.77 \\ \text { M4W9 } & \text { 22-May-15 } & 0.01 & -0.30 & -0.16 & -1.29 & -0.96 \\ \text { M1ESW } & \text { 22-May-15 } & 0.01 & -0.07 & 0.07 & -0.69 & -1.64 \\ \text { M1WSW } & \text { 22-May-15 } & 0.01 & -0.07 & 0.07 & -0.69 & -1.64 \\ & & & & & & \end{array}$




\begin{tabular}{|c|c|c|c|c|c|c|}
\hline Name Sample & $\begin{array}{c}\text { Date } \\
\text { Collection }\end{array}$ & IS & SI $\mathbf{I}_{\text {aragonite }}$ & SI $\mathbf{I}_{\text {calcite }}$ & $\mathbf{S I}_{\text {dolomite }}$ & $\log \left(p \mathrm{CO}_{2}\right)$ \\
\hline M2ESW & 22-Мay-15 & 0.01 & 0.00 & 0.14 & -0.41 & -1.71 \\
\hline M2WSW & 22-May-15 & 0.01 & 0.27 & 0.41 & 0.25 & -2.17 \\
\hline M3ESW & 22-Мay-15 & 0.01 & 0.33 & 0.47 & 0.19 & -2.06 \\
\hline M3WSW & 22-May-15 & 0.01 & 0.33 & 0.47 & 0.19 & -2.06 \\
\hline M4ESW & 22-Мay-15 & 0.01 & 0.03 & 0.17 & -0.38 & -1.92 \\
\hline M4WSW & 22-Мay-15 & 0.01 & 0.03 & 0.17 & -0.38 & -1.92 \\
\hline M1E10S & $20-O c t-15$ & 0.01 & -0.20 & -0.06 & -0.84 & -0.91 \\
\hline M1E12R & $20-O c t-15$ & 0.01 & -0.60 & -0.46 & -1.57 & -0.93 \\
\hline M1E4 & $20-O c t-15$ & 0.02 & -0.02 & 0.12 & -0.61 & -0.76 \\
\hline M1E5 & $20-O c t-15$ & 0.03 & 0.55 & 0.69 & 0.64 & -0.86 \\
\hline M1W5 & 20-Oct-15 & 0.02 & 0.05 & 0.20 & -0.43 & -0.75 \\
\hline M1W5 Shallow & $20-O c t-15$ & 0.04 & 0.59 & 0.73 & 0.57 & -0.76 \\
\hline M1W8 & $20-O c t-15$ & 0.02 & -0.01 & 0.13 & -0.57 & -0.79 \\
\hline M1W8 Deep & $20-O c t-15$ & 0.03 & 0.09 & 0.23 & -0.36 & -0.71 \\
\hline M2E10S & $20-O c t-15$ & 0.01 & -0.17 & -0.03 & -0.96 & -0.91 \\
\hline M2E12R & 20-Oct-15 & 0.01 & -0.54 & -0.40 & -1.64 & -0.91 \\
\hline M2E4 & $20-O c t-15$ & 0.01 & -0.45 & -0.31 & -1.54 & -1.03 \\
\hline M2E5 & $20-O c t-15$ & 0.02 & -0.27 & -0.12 & -0.97 & -0.72 \\
\hline M2W5 & $20-O c t-15$ & 0.02 & 0.13 & 0.27 & -0.38 & -1.01 \\
\hline M2W9 & $20-O c t-15$ & 0.01 & -0.40 & -0.26 & -1.29 & -0.68 \\
\hline M3E10S & $20-O c t-15$ & 0.01 & 0.86 & 1.01 & 1.24 & -1.83 \\
\hline M3E12R & $20-O c t-15$ & 0.01 & 0.05 & 0.20 & -0.30 & -1.76 \\
\hline M3E4 & $20-O c t-15$ & 0.01 & -0.49 & -0.35 & -1.54 & -0.70 \\
\hline M3E5 & $20-O c t-15$ & 0.04 & 0.39 & 0.54 & 0.36 & -0.68 \\
\hline M3E8 Deep & $20-O c t-15$ & 0.04 & 1.05 & 1.19 & 1.59 & -1.41 \\
\hline M3W5 & $20-O c t-15$ & 0.02 & -0.16 & -0.02 & -0.86 & -0.80 \\
\hline M3W9 & $20-O c t-15$ & 0.02 & 0.12 & 0.26 & -0.39 & -0.87 \\
\hline
\end{tabular}




$\begin{array}{ccccccc}\text { Name Sample } & \begin{array}{c}\text { Date } \\ \text { Collection }\end{array} & \mathbf{I S} & \mathbf{S I}_{\text {aragonite }} & \mathbf{S I}_{\text {calcite }} & \mathbf{S I}_{\text {dolomite }} & \log \left(\boldsymbol{p} \mathbf{C O}_{2}\right) \\ \text { M4E10S } & \text { 20-Oct-15 } & 0.01 & -0.28 & -0.14 & -1.22 & -1.02 \\ \text { M4E12R } & \text { 20-Oct-15 } & 0.01 & -1.02 & -0.88 & -2.47 & -0.78 \\ \text { M4E4 } & \text { 20-Oct-15 } & 0.01 & -0.18 & -0.03 & -0.96 & -0.93 \\ \text { M4E5 } & \text { 20-Oct-15 } & 0.03 & 0.54 & 0.69 & 0.59 & -1.16 \\ \text { M4W5 } & \text { 20-Oct-15 } & 0.02 & -0.13 & 0.01 & -0.82 & -0.63 \\ \text { M4W9 } & \text { 20-Oct-15 } & 0.01 & -0.71 & -0.56 & -2.03 & -0.89 \\ \text { M1ESW } & \text { 20-Oct-15 } & 0.01 & -0.24 & -0.09 & -1.01 & -2.01 \\ \text { M1WSW } & \text { 20-Oct-15 } & 0.01 & 0.05 & 0.20 & -0.45 & -2.24 \\ \text { M2ESW } & \text { 20-Oct-15 } & 0.00 & -0.98 & -0.84 & -2.46 & -1.46 \\ \text { M2WSW } & \text { 20-Oct-15 } & 0.01 & -0.15 & 0.00 & -0.78 & -2.21 \\ \text { M3ESW } & \text { 20-Oct-15 } & 0.01 & -0.30 & -0.16 & -1.13 & -1.99 \\ \text { M3WSW } & \text { 20-Oct-15 } & 0.01 & -0.40 & -0.26 & -1.32 & -1.79 \\ \text { M4ESW } & \text { 20-Oct-15 } & 0.01 & -0.05 & 0.09 & -0.58 & -2.33 \\ \text { M4WSW } & \text { 20-Oct-15 } & 0.01 & -0.35 & -0.21 & -1.23 & -1.90\end{array}$

4, 8, 9 = Edge; 5 = Center; $\mathrm{S}=$ Slough; $\mathrm{R}=$ Ridge; $\mathrm{SW}=$ Surface Water 